\title{
WestVirginiaUniversity
}

THE RESEARCH REPOSITORY @ WVU

Graduate Theses, Dissertations, and Problem Reports

2010

\section{Essays on housing markets and economic *growth}

Arzu Sen

West Virginia University

Follow this and additional works at: https://researchrepository.wvu.edu/etd

\section{Recommended Citation}

Sen, Arzu, "Essays on housing markets and economic *growth" (2010). Graduate Theses, Dissertations, and Problem Reports. 4652.

https://researchrepository.wvu.edu/etd/4652

This Dissertation is protected by copyright and/or related rights. It has been brought to you by the The Research Repository @ WVU with permission from the rights-holder(s). You are free to use this Dissertation in any way that is permitted by the copyright and related rights legislation that applies to your use. For other uses you must obtain permission from the rights-holder(s) directly, unless additional rights are indicated by a Creative Commons license in the record and/ or on the work itself. This Dissertation has been accepted for inclusion in WVU Graduate Theses, Dissertations, and Problem Reports collection by an authorized administrator of The Research Repository @ WVU.

For more information, please contact researchrepository@mail.wvu.edu. 


\title{
Essays on Housing Markets and Economic Growth
}

\author{
Arzu Sen \\ Dissertation Submitted to the \\ College of Business and Economics at \\ West Virginia University \\ In partial fulfillment of the requirements for the degree of \\ Doctor of Philosophy \\ in \\ Economics
}
Brian J. Cushing, Ph.D., Chair Tim T. Phipps, Ph.D.
Peter V. Schaeffer, Ph.D.
Russell S. Sobel, Ph.D.
Tami Gurley-Calvez, Ph.D.
Department of Economics
Morgantown, West Virginia 2010

Keywords: Hedonic prices, environmental disamenities, county economic growth, resource curse, spatial econometrics

Copyright 2010 Arzu Sen 


\title{
ABSTRACT \\ Essays on Housing Markets and Economic Growth
}

\begin{abstract}
Arzu Sen
This dissertation is composed of three essays examining housing markets and economic growth, while carefully considering the role of space. The first chapter serves as an introduction and briefly discusses how each essay contributes to the literature. The second chapter estimates the relationship between residential property values and proximity to coal mines in Monongalia County, West Virginia. The study utilizes a spatial hedonic price model complemented with GIS techniques to estimate the marginal willingness to pay for properties surrounding coal mines. Study findings indicate that proximity to a coal mine translates negatively into property values. The third chapter is related to spatial county growth. Growth theories do not fully specify the prominent factors underlying the data-generating process for growth regressions. Introduction of space in growth regressions further complicates the estimations by adding uncertainty regarding the use of an appropriate spatial weight matrix and spatial regression specification. This study applies Markov Chain Monte Carlo model composition with the Bayesian model averaging methodology on a sample of U.S. counties, to deal with model uncertainty in spatial growth regressions. This study reports model averaged estimates to resolve the uncertainty pertaining to the determinants of U.S. county growth. The fourth chapter is related to the resource curse. An extensive literature has examined the presence and the possible causal mechanisms of a resource curse using a resource dependence indicator. However, a strand of the literature argues that switching from relative measures of resource abundance to absolute measures of resource abundance makes the resource curse disappear across countries. This study contributes to this strand of literature by examining whether coal abundance is a curse or a blessing for county economic growth, using both an absolute and a relative measure of resource abundance. Unlike previous research on resource curse, this study employs spatial county growth regressions to account for spatial dependence. Study findings suggest that introducing spatial dependence into growth regressions changes the results from non-spatial models drastically. When measured as a relative variable, coal dependence has a significant positive direct impact on own-county growth, and positive spillovers on related counties' growth. When measured as an absolute variable, coal abundance does not impact owncounty growth, nor imposes spatial spillovers. Results imply that switching from nonspatial growth models to spatial growth models reverses the resource curse. Chapter 5 concludes and discusses areas of future research.
\end{abstract}




\section{ACKNOWLEDGEMENTS}

I would like to express my deepest appreciation to my dissertation chair, Professor Brian Cushing, for his extraordinary support and motivation throughout my graduate education. Without his guidance and persistent help, this dissertation would not have been possible. I will forever be grateful to him. I would also like to thank the members of my dissertation committee Dr. Tim T. Phipps, Dr. Peter V. Schaeffer, Dr. Russell S. Sobel, and Dr. Tami Gurley-Calvez for providing helpful comments, insights, and advice. I would also like to thank the faculty and fellow graduate students in the Economics Department at West Virginia University for all of their help and support. Finally, I cannot thank my parents enough for supporting and motivating me throughout my life. 


\section{Table of Contents}

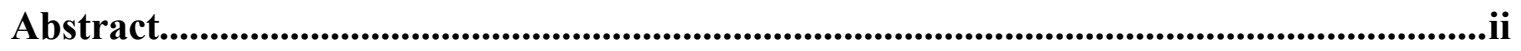

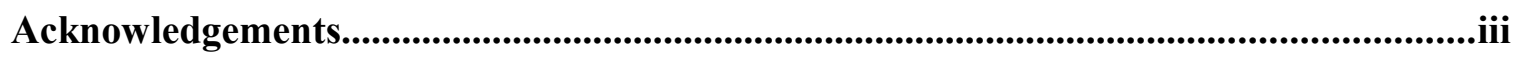

List of Tables................................................................................................................................

List of Figures..............................................................................................................................

Introduction.........................................................................................................................................................1

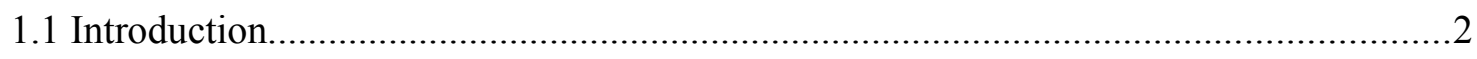

Effects of Coal Mines on Residential Property Values: A Spatial Hedonic Analysis........8

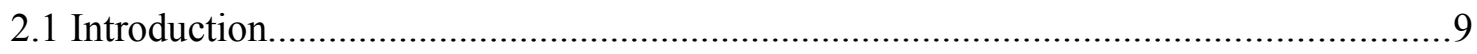

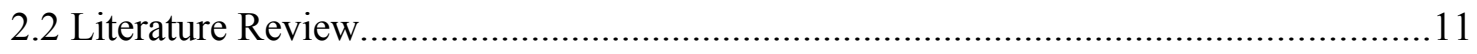

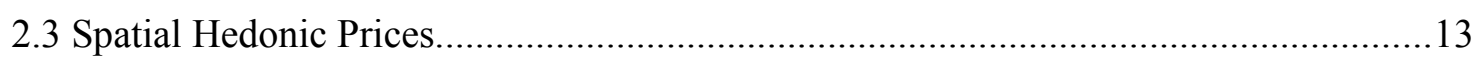

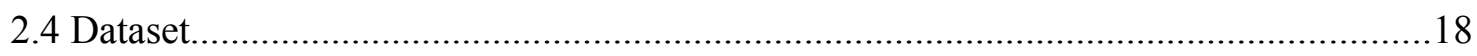

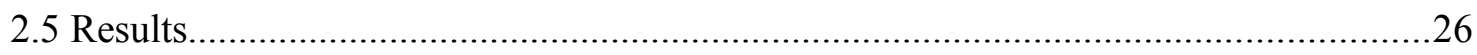

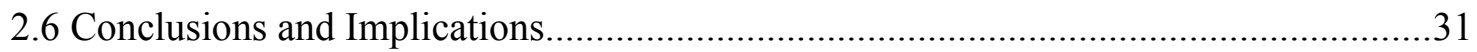

U.S. County Growth: A Bayesian Model Averaging Approach...........................................33

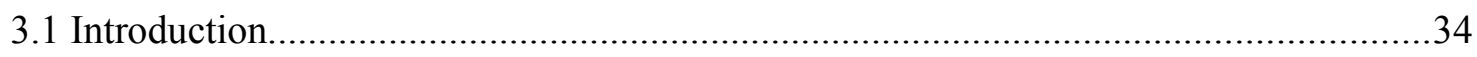

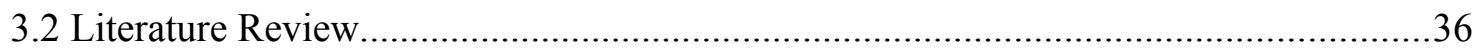

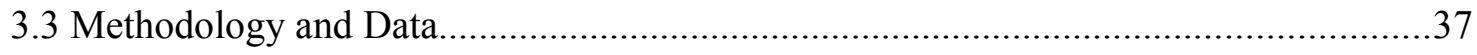

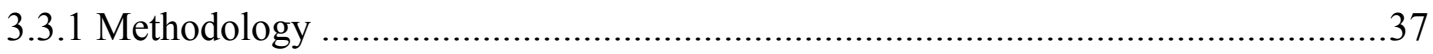

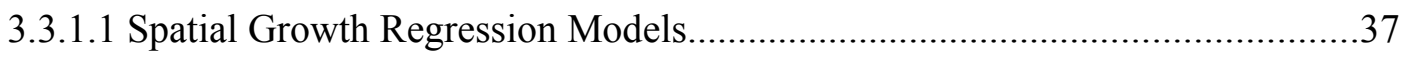

3.3.1.2 Bayesian Model Averaging................................................................ 43

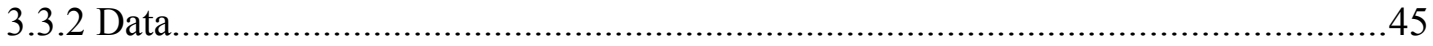

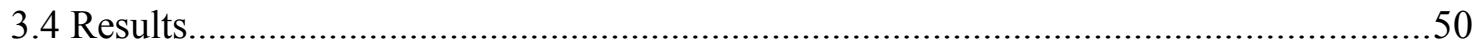

3.4.1 Results of the Bayesian Heteroskedastic Spatial Durbin Model...........................50

3.4.2 Results of the Bayesian Model Averaging......................................................55

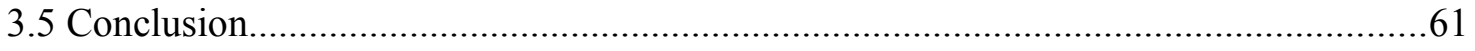

Resource Curse in U.S. Coal Counties: A Spatial County Growth Analysis...................62

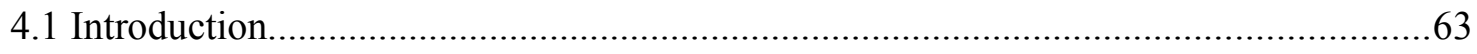

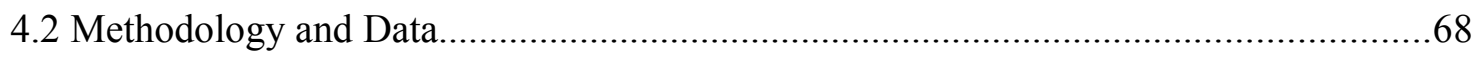

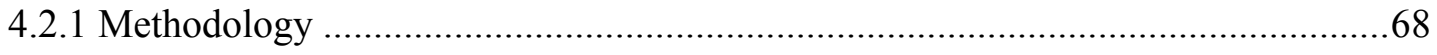

4.2.1.1 Spatial Growth Regression Models...............................................................68 
4.2.1.2 Bayesian Model Averaging. .74

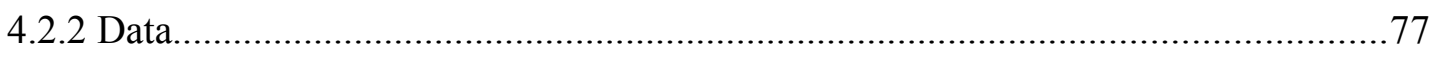

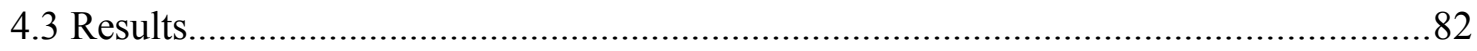

4.3.1 Results of the Bayesian Heteroskedastic Spatial Durbin Model............................82

4.3.2 Results of the Bayesian Model Averaging..........................................................91

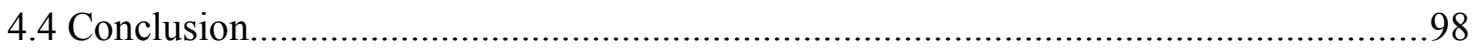

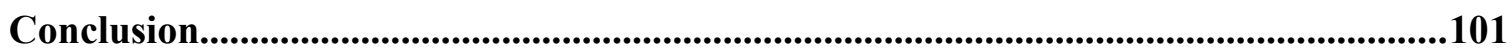

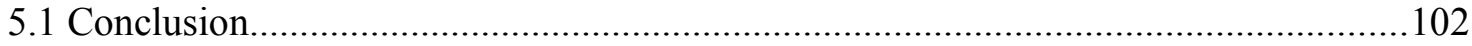

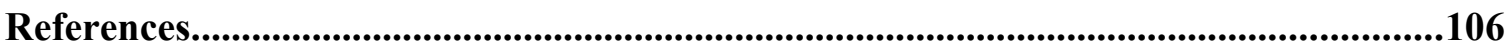




\section{LIST OF TABLES}

Table 2.1. Summary Results for Bayesian Model Selection............................................16

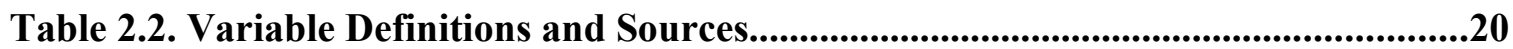

Table 2.3. Descriptive Statistics................................................................................................21

Table 2.4. Direct, Indirect, and Total Effects Estimates.................................................27

Table 3.1. Summary Results for Bayesian Model Selection...............................................41

Table 3.2. Variable Definitions and Sources......................................................................47

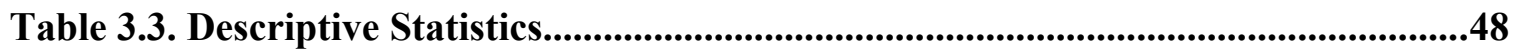

Table 3.4. Direct, Indirect, and Total Effects Estimates with Contiguity

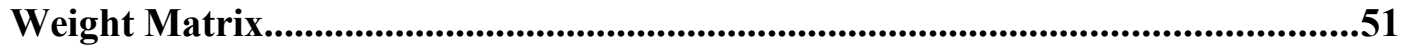

Table 3.5. Direct, Indirect, and Total Effects Estimates with 14 Nearest Neighbors......52

Table 3.6. High-probability Models..................................................................................57

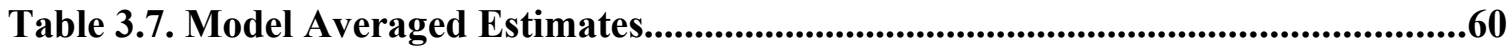

Table 4.1. Summary Results for Bayesian Model Selection...................................................72

Table 4.2. Variable Definitions and Sources.......................................................................79

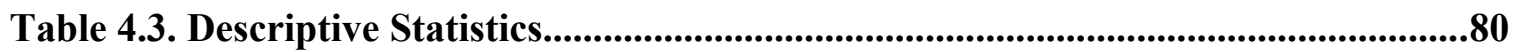

Table 4.4. Direct, Indirect, and Total Effects Estimates with Contiguity

Weight Matrix and an Absolute Measure of Coal Abundance..................................84

Table 4.5. Direct, Indirect, and Total Effects Estimates with Contiguity

Weight Matrix and a Relative Measure of Coal Dependence.................................85

Table 4.6. Direct, Indirect, and Total Effects Estimates with 14 Nearest

Neighbors and an Absolute Measure of Coal Abundance......................................86

Table 4.7. Direct, Indirect, and Total Effects Estimates with 14 Nearest

Neighbors and a Relative Measure of Coal Dependence...........................................87

Table 4.8. OLS Results with an Absolute and a Relative Measure of

Coal Abundance.........................................................................................................................88

Table 4.9. High-probability Models.............................................................................................92

Table 4.10. Model Averaged Estimates with Absolute Coal Abundance Measure..........96

Table 4.11. Model Averaged Estimates with Relative Coal Dependence Measure..........97 


\section{LIST OF FIGURES}

Figure 2.1. House Sales in the Study Area..............................................................................24

Figure 2.2. Active Coal Mines in the Study Area...................................................................25

Figure 2.3. House Sales and Active Coal Mines in the Study Area.....................................26 
Chapter 1

\section{Introduction}




\subsection{Introduction}

The role of space is central to the literature in urban and regional economics. It is often the case that sample data is collected with reference to location measured as points in space. The locational component of data results with spatial dependence among related observations and spatial heterogeneity when a particular region follows a different relationship from that of the majority. Spatial dependence and spatial heterogeneity have been increasingly accounted for in the literature on locational externalities and housing markets. It has for the most part been ignored in regional growth literature. The three essays of this dissertation further advance the application of spatial econometrics in the literature on locational externalities/housing markets and regional economic growth, by appropriately accounting for spatial dependence and spatial heterogeneity.

Locational externalities in housing markets have long captured the attention of researchers and policy makers. Since many of the costs associated with locational externalities are spatially concentrated in the immediate environment, their presence may affect household location decisions and housing prices. Previous literature on housing markets has detected price differentials arising among different locations for many locational externalities including proximity to environmental hazards (Brasington and Hite, 2005), proximity to nuclear power plants (Gamble and Downing, 1982; Clark et. al., 1997), proximity to airports (Tomkins et al., 1998; Espey and Lopez, 2000; Kiel and McClain, 1995), proximity to landfills (Hite et al., 2001), and proximity to high voltage power lines (Delaney and Timmons, 1992; Des Rosiers, 2002).

A number of disamenity characteristics connected to coal mining can affect household location decisions and housing prices. Properties near coal mines often suffer 
from dust and noise pollution, and sometimes explosions. They are also vulnerable to the risk of land subsidence, which may result in serious property damage, land damage or water supply impacts. Moreover, coal communities are exposed to coal pollution and often suffer from serious health outcomes. Coal related disamenities have the potential to affect household location decisions and housing prices, since households would only choose to purchase a property near a coal mine if they expect some form of compensation, such as lower housing prices. Locational externalities connected to coal mines constitute a potential issue for the residents of more than three hundred coal producing counties in the U.S. This dissertation provides powerful insights regarding the extent to which such proximity effects are capitalized into residential property values and additionally, incorporates Geographic Information Systems (GIS) techniques and recent advancements in spatial econometrics.

This study employs a Bayesian heteroskedastic SAR estimation procedure described in LeSage and Pace (2009), which allows for outliers and non-constant variance across space. Bayesian estimation also proves fruitful in solving model comparison problems. Comparing models with different number of neighbors (different weight matrices) and different model specifications (SAR, SEM and SDM) yields SAR with two optimal nearest neighbors as the model specification with the highest probability of describing data.

Findings indicate that proximity to a coal mine translates negatively into house values. The farther the house is from a coal mine, the smaller the effect of disamenity on house price. The average sales price of a house located within $3 / 4$ mile of a coal mine is 16 percent lower, whereas a house located within $3 / 4$ to 1 mile experiences an 11 percent 
discount. Houses located within the next quarter of a mile sell for 10 percent less. Proximity effects disappear beyond $1 \frac{1}{4}$ miles.

The second essay in my dissertation is related to spatial county growth. Growth theories partially specify the prominent factors that underlie the data-generating process for growth regressions. When faced with model uncertainty, researchers often introduce a large set of variables and try to identify the important factors. However, using a large set of variables increases the dispersion of estimated coefficients and complicates the identification of prominent factors (Levine and Renelt, 1992; Pack, 1994; Sala-i-Martin, 1997; Schultz, 1999; Durlauf and Quah, 1999; Fernandez, Ley and Steel, 2001a; LeSage and Fischer, 2008).

Another complication in growth regressions can arise with the introduction of space in growth regressions. This adds the uncertainty regarding the use of an appropriate spatial weight matrix that describes the structure of the spatial dependence between regions. Spatial growth regression models produce estimates and inferences that are conditional on both the particular weight matrix used to specify the spatial dependence and the explanatory variables included in the growth regression. Employing different spatial weight matrices may change the dispersion of the estimated coefficients, further complicating the identification of important growth factors.

Another source of model uncertainty can arise from the use of an appropriate spatial regression specification. Typically, the models used to account for spatial dependence are the Spatial Autoregressive (SAR), the Spatial Error Model (SEM), and the Spatial Durbin Model (SDM). The SAR model consists of a spatial lag of the dependent variable, whereas the SEM corrects for spatial correlation in the disturbance 
term. The SDM includes spatial lags of the explanatory variables, as well as the spatial lag of the dependent variable. Selection of an appropriate specification is central to the analysis of spatial growth regressions.

This study fills the gap in the regional growth literature by applying Markov Chain Monte Carlo model composition $\left(\mathrm{MC}^{3}\right)$ with the Bayesian model averaging methodology on a sample of U.S. counties, to deal with model uncertainty in spatial growth regressions.

This essay first reports spatial growth regression estimates using two different spatial weights matrix specifications, first-order contiguity (borders-touching) and optimal nearest neighbors, to demonstrate how different weight matrix specifications may lead to ambiguous results in spatial county growth regressions. Later, Bayesian model averaging is employed to produce model averaged estimates and inferences that would embody model uncertainty.

The third essay in my dissertation is related to the resource curse. The negative association between resource abundance and poor economic performance has captured the attention of a wide range of audience, including academics, policy makers and international organizations. An extensive literature has examined the presence and the possible causal mechanisms of a resource curse using a resource dependence indicator such as the share of primary exports in GDP (Sachs and Warner, 1995; 2001; Auty 2001; Torvik 2001; Leite and Weidmann, 1999). However, several researchers object to the use of resource dependence measures and argue that switching from relative measures of resource abundance to absolute measures of resource abundance makes the resource curse disappear across countries (Stijns, 2005; Brunnschweiler, 2007). Later, 
Brunnschweiler and Bulte (2008) show that the ratio of resource exports to GDP suffers from endogeneity problems. They employ both an absolute and a relative measure of resource abundance and find that resource abundance, constitutions and institutions determine resource dependence. They conclude that resource abundance positively affects growth and institutional quality, whereas resource dependence does not affect growth. This dissertation contributes to this strand of literature by employing U.S. county level growth regressions and using both an absolute and a relative measure of resource abundance. Another contribution of this paper is the employment of the appropriate spatial econometrics techniques in growth regressions to account for spatial spillovers. Unlike previous research on resource curse, this study accounts for spatial dependence among related counties.

Using the methodology introduced in the third chapter of this dissertation, the fourth chapter examines whether coal abundance is a curse or a blessing for county economic growth, using U.S. county-level data for the period 1980-1999. The study uses both an absolute measure of coal abundance and a relative measure of coal dependence.

The SDM specification for spatial growth models introduced by LeSage and Fischer (2008) is employed. The Bayesian heteroskedastic SDM estimation procedure described in LeSage and Pace (2009) is utilized to allow for outliers and non-constant variance across space. First, this study reports results obtained from employing two different weight matrix specifications, using both the absolute and the relative indicators of coal abundance. Following the conventional approach of defining regions as neighbors with a common border, the study uses first-order contiguity (county borders touching) as the first type of weight matrix. The second weight matrix specification is the optimal 
nearest neighbors. The Bayesian model comparison supports the use of the SDM with an optimal number of fourteen nearest neighbors. Next, these results are compared with OLS estimation results. Finally, the Bayesian model averaging is employed to deal with model uncertainty resulting from different specifications, and model averaged estimates and inferences are discussed.

The findings suggest that introducing spatial dependence into growth regressions changes the results from OLS regressions drastically. When a relative measure of coal dependence is used, OLS results suggest a coal curse, while an absolute measure of coal abundance is not significant. These OLS results are consistent with the strand of crosscountry growth literature that suggests that switching from relative measures of resource dependence to absolute measures of resource abundance makes the resource curse disappear across countries (Stijns, 2005; Brunnschweiler, 2007). This study employs spatial econometrics and reveals that the signs of the absolute and the relative coal abundance variables are reversed with the introduction of spatial dependence into county growth regressions. Unlike non-spatial models, the results suggest that when measured as a relative variable, coal dependence turns out to have a positive significant direct impact on own-county growth, and positive spillover impacts on related counties' growth. On the other hand, when measured as an absolute variable, coal abundance does not impact owncounty growth, nor imposes spatial spillovers. This implies that switching from nonspatial growth models to spatial growth models makes the coal curse disappear.

The fifth chapter of this dissertation concludes with a summary of the major results found in each essay. This chapter will also include a discussion of possible future extensions. 


\title{
Chapter 2
}

\section{Effects of Coal Mines on Residential Property}

\author{
Values: A Spatial Hedonic Analysis
}




\subsection{Introduction}

Coal mining can potentially influence property values in a number of ways. On the one hand, accessibility to workplace may positively influence housing values. For instance, when a new coal mine starts its operation, it is likely to attract employees to nearby communities. As developers alleviate accommodation shortages, coal communities may experience a property boom and an increase in housing prices. On the other hand, properties located around coal mines often suffer from dust and noise pollution, and sometimes explosions, as well as the risk of land subsidence, which may cause serious damage on properties, land, and infrastructure. Furthermore, coal communities are exposed to coal pollution, and often suffer from serious health outcomes. Hendryx and Ahern (2008; 2009), and Hendryx (2009) find that residents of coal counties in the Appalachian region are more likely to suffer from chronic heart, kidney, and lung diseases; and more likely to be hospitalized for health problems connected to coal pollution.

Since many of the costs and benefits associated with coal mining are spatially concentrated in the immediate environment, their presence may affect household location decisions and housing prices. Households would purchase a property near a coal mine, if they expect some form of compensation (e.g., lower housing prices or accessibility to work places). Locational externalities related to coal mining constitute a potential issue for the residents of more than three hundred coal producing counties in the US. Therefore, an empirical analysis will provide important insights regarding the extent to which such proximity effects are capitalized into residential property values. 
This paper is related to a growing literature on housing markets which has studied price differentials among different locations resulting from externalities such as environmental hazards, airport noise, and air pollution (see, for example, Kim et al. 2003; Brasington and Hite, 2005; Cohen and Coughlin, 2008). However, none of these studies have investigated the relation between coal mines and property values. Using geo-coded 2004-2005 house sales data for Monongalia County, West Virginia, this study quantifies the influence of proximity to a coal mine on residential property values and provides marginal willingness to pay estimates for properties surrounding coal mines.

Another contribution of this paper is the utilization of appropriate spatial econometric techniques to distinguish between direct, indirect, and total effects. Spatial econometric techniques prove fruitful when observations are spatially dependent. It is often the case that the sales price of a house is influenced by those of neighboring houses. For instance, a change in own-house characteristic, which increases the price of your house, will increase the price of your neighbors' house, which will further increase the price of your house. Significant spillover estimates of this study support the use of spatial econometrics in hedonic analyses. Ignoring the spatial effects can lead to biased and inconsistent parameter estimates (Anselin, 1988; Anselin and Bera, 1998).

Results of this study support the argument of negative externalities and discounted house prices for coal community residents. Spatial hedonic analysis results reveal that the implicit price of proximity to coal mines has a negative distance gradient. The farther the house is from a coal mine, the smaller the effect of disamenity on house price. The average sales price of a house located within $3 / 4$ mile of a coal mine is 16 percent lower, whereas a house located within $3 / 4$ to 1 mile experiences an 11 percent 
discount. Houses located within the next quarter of a mile sell for 10 percent less. Proximity effects disappear beyond $1 \frac{1}{4}$ miles. Proximity to coal mines is associated with both significant negative direct effects on own-house value and negative spillover effects on neighboring house values. The results reinforce previous hedonic analyses of environmental hazards that find a significant negative impact on house prices. Study findings facilitate a better understanding of the costs coal mines impose on surrounding communities. Any cost-benefit analyses of coal mines should also consider discounted house values.

The remainder of the paper is organized as follows. Section 2 reviews the literature, section 3 describes the methodology, section 4 illustrates the data, section 5 discusses the results, and section 6 concludes.

\subsection{Literature Review}

The formulation of the hedonic price model is associated with Rosen (1974). Since then, an extensive literature examining various applications of the hedonic model has emerged in regional science. Typically, these studies regress actual sales prices of houses on various tangible and intangible housing attributes to obtain the implicit price for each attribute. While most of the previous work uses simple ordinary least squares estimation to obtain implicit marginal prices, most of the recent work uses spatial econometrics to account for spatial dependence in house prices among neighboring properties.

Hedonic models have been applied to various locational externalities to estimate their impact on house values. Research includes studies of the nonmarket value of agricultural land (Shi et al., 1997), open space (Irwin, 2002; Geoghegan et al., 2003; 
Anderson and West, 2006), air quality (Kim et al., 2003; Graves et al., 1988; Chattopadhyay, 1999), water quality (Hoehn et al., 1987; Des Rosiers et. al., 1999), proximity to primary schools (Guntermann and Colwell, 1983), proximity to environmental hazards (Brasington and Hite, 2005), proximity to nuclear power plants (Gamble and Downing, 1982; Clark et. al., 1997), proximity to airports (Tomkins et al., 1998; Espey and Lopez, 2000; Kiel and McClain, 1995), proximity to landfills (Hite et al., 2001), and proximity to high voltage power lines (Delaney and Timmons, 1992; Des Rosiers, 2002).

Previous studies of environmental quality found a statistically significant relationship with house prices. Brasington and Hite (2005) used a distance to the nearest hazard variable to measure the effect of several environmental hazards on house prices. They found that increasing the average distance of a house from the nearest environmental hazard by 1 percent increases the price of an average house by 0.029 percent at the mean. Cohen and Coughlin (2008) used dummy variables to control for houses located in different noise contours and found that houses located in areas where noise disrupts normal activities sell for 20.8 percent less compared with areas where noise is not disruptive. Williamson et al. (2008) used two buffer dummies to control properties within $1 / 4$ mile and $1 / 4$ to $1 / 2$ mile of an acid mine drainage-impaired stream. Their results suggest that houses located within a $1 / 4$ mile of an acid mine drainageimpaired stream sell for 12.2 percent less. 


\subsection{Spatial Hedonic Price Model}

Hedonic models are based on the idea that differentiated goods are valued for their attributes. Housing is a differentiated good and the differentiated bundles of attributes collectively determine the value of a house. The price paid for a particular house is the sum of the implicit prices that the market ascribes to the various tangible and intangible attributes contained in the housing bundle. Tangible attributes may include structural attributes such as the building size, bedrooms, bathrooms, and quality. Intangible attributes may comprise neighborhood and environmental characteristics such as income, crime rate or air quality. Comprised among intangible attributes, location is one important attribute that can provide proximity to many amenities, including schools, employment, and shopping centers. Location can also provide remoteness from undesirable disamenities, such as noise and pollution creating coal mines, airports, or hazardous sites. At the consumer equilibrium in the housing market, consumers maximize their utility subject to a budget constraint and choose the combination of attributes that satisfy their preferences.

The hedonic market equilibrium necessitates price differentials among different locations to compensate consumers for differences in housing services. Intuitively, people would prefer a clean environment. However, a clean environment is a nonmarket good and there is no explicit market to indicate how much consumers value it. Yet, nonmarket goods are implicitly traded in the housing market. Consumers reveal their preferences for a clean environment in the housing market by purchasing a house in a clean area. The extra that is paid for the one of two identical houses in a clean area reflects the value of 
cleanliness that consumers ascribe. This difference is referred as the price differential in the housing market.

The basic hedonic implicit price function of a house can be written as follows:

$$
y=X \beta+\varepsilon
$$

where $y$ represents actual sale prices of individual houses, $X$ is a vector of explanatory variables, which may include structural, neighborhood and locational attributes, and $\varepsilon$ is the error term assumed to be normally distributed with a mean of zero and constant variance.

The implicit price for any attribute can be derived by taking the partial derivative of the hedonic price function with respect to that attribute. For instance, the partial derivative of the hedonic price function with respect to the number of bedrooms can be interpreted as the change in expenditures on housing that is required to obtain a house with one more unit of bedroom, all else constant.

It is commonly noted that housing prices are spatially dependent; meaning that sales price of a house is affected by those of neighboring houses. OLS does not account for spatial dependence between observations and leads to biased and inconsistent parameter estimates (Anselin, 1988; Anselin and Bera, 1998). Using an econometric model that allows for spatial dependence would produce lower standard errors and consistent coefficient estimates ${ }^{1}$.

Spatial regression models are highly beneficial, as they discern the estimation of direct effects resulting from a change in own-explanatory variables on own-house prices from indirect effects (also termed as spillover effects) corresponding to effects resulting from a change in own-explanatory variables on neighboring houses. The sum of these

\footnotetext{
${ }^{1}$ See Anselin and Bera (1998) for details on spatial dependence in linear regression models.
} 
two effects constitutes the total effect $^{2}$. Regarding the housing market, spatial econometric models enable separate estimation of the effect of an increase in own building size on own house price and that of the neighboring houses' prices. The direct effects are expected to be prominent; however, when cumulated over neighboring houses, spillover effects can be substantial.

Predominantly, the models used to account for spatial dependence are the spatial autoregressive (SAR), the spatial error model (SEM), and the spatial Durbin model (SDM). The SAR model consists of a spatial lag of the dependent variable, whereas the SEM corrects for spatial correlation in the disturbance term. The SDM includes spatial lags of the explanatory variables as well as the spatial lag of the dependent variable.

This study follows the Bayesian model comparison defined in Lesage and Pace $(2009)^{3}$. First, the SAR models with different number of nearest neighbors weight matrix specifications ( 1 to 10 nearest neighbors) are run against each other. The winner is the SAR model with 2 nearest neighbors. Next, the same procedure is implemented on the SEM and the SDM specifications. The SEM with 5 nearest neighbors and the SDM with 8 nearest neighbors are the winner model specifications. Finally, the winners of the above process; the SAR model with 2 nearest neighbors, the SEM with 5 nearest neighbors, and the SDM with 8 nearest neighbors specifications are run against each other. The model specification that has the highest probability of describing the data is found as the SAR model with an optimal number of 2 nearest neighbors. When run against each other, the SAR model with a spatial weight matrix of 2 nearest neighbors produces a probability of 1, whereas the other models with different neighbor specifications result in probabilities

\footnotetext{
${ }^{2}$ See LeSage and Pace (2009) for details on interpretation of the parameters from spatial regressions. ${ }^{3}$ See LeSage and Pace (2009) for details on Bayesian model selection for different model specifications and different weight matrices.
} 
of zero. A summary of the results for different model specifications is provided in Table 2.1.

\section{Table 2.1: Summary Results for Bayesian Model Selection}

\begin{tabular}{cccc}
\hline \multirow{2}{*}{$\begin{array}{c}\text { Number of Nearest } \\
\text { Neighbors }\end{array}$} & SAR & SEM & SDM \\
$\mathbf{1}$ & 0.10 & 0.00 & 0.00 \\
$\mathbf{2}$ & $\mathbf{0 . 9 0}$ & 0.00 & 0.00 \\
$\mathbf{3}$ & 0.00 & 0.00 & 0.00 \\
$\mathbf{4}$ & 0.00 & 0.04 & 0.00 \\
$\mathbf{5}$ & 0.00 & $\mathbf{0 . 9 0}$ & 0.00 \\
$\mathbf{6}$ & 0.00 & 0.00 & 0.00 \\
$\mathbf{7}$ & 0.00 & 0.06 & 0.00 \\
$\mathbf{8}$ & 0.00 & 0.00 & $\mathbf{0 . 9 5}$ \\
$\mathbf{9}$ & 0.00 & 0.00 & 0.05 \\
$\mathbf{1 0}$ & 0.00 & 0.00 & 0.00 \\
Final Run & $\mathbf{1 . 0 0}$ & 0.00 & 0.00 \\
\hline
\end{tabular}

The SAR model is specified as follows:

$$
y=\rho W y+X \beta+\varepsilon
$$

where

$$
\varepsilon \sim N\left(0, \sigma^{2} I_{n}\right)
$$

$W$ is an $n x n$ spatial weight matrix based on a chosen number of nearest neighbors and normalized to have row sums of one. The matrix assigns a weight of $1 / 2$ to the nearest 2 neighbors and 0 to all others. $W y$ is called a spatial lag as it expresses a linear combination of values of the variable $y$ constructed from observations that neighbor observation $i$. Wy results in a scalar that represents the average sales value of neighboring houses. The weight matrix captures spatial dependence in $y$, with the scalar parameter $\rho$, which provides a measure of average or overall influence of neighboring house prices on own-house prices. In spatial hedonic regressions, $\rho$ is expected to have a value between 
zero and one, indicating that own-house prices are positively related to a linear combination of neighboring house prices.

This study employs the Bayesian heteroskedastic SAR estimation procedure described in LeSage and Pace (2009), which allows for non-constant variance across space as well as outliers ${ }^{4}$. When a particular region follows a different relationship from that of the majority of spatial observations, the error terms are no longer normal, but more likely to follow a Student-t distribution. Introducing a set of variance scalars $\left(v_{1}, \ldots, v_{n}\right)$ as unknown parameters to be estimated allows the assumption of non-constant variance across space; unit estimates of $v_{i}$ would be indicative of constant variance, whereas large estimates of $v_{i}$ would be indicative of heteroskedasticity or outliers. Large $v_{i}$ values accommodate outliers or observations with large variances by downweighting these observations.

The Bayesian heteroskedastic SAR model is specified as follows:

$$
\begin{aligned}
& y=\rho W y+X \beta+\varepsilon \\
& \varepsilon \sim N\left(0, \sigma^{2} V\right) \quad V=\operatorname{diag}\left(v_{1}, \ldots, v_{n}\right) \\
& \pi(\beta) \sim N(c, T) \\
& \pi\left(r / v_{i}\right) \sim \operatorname{iid} \chi^{2}(r) \\
& \pi\left(1 / \sigma^{2}\right) \sim \Gamma(d, v) \\
& \pi(\rho) \sim U[-1,1]
\end{aligned}
$$

The Bayesian approach assumes the parameters to be estimated $\left(\beta, \sigma, \rho\right.$ and $\left.v_{i}\right)$ follow prior distributions, or prior beliefs. The prior distributions are indicated by $\pi$. $\beta$

\footnotetext{
${ }^{4}$ The Bayesian approach has two important advantages. First, it makes model comparison across different weights matrix specifications fairly easy. Second, it accounts for outliers or non-constant variance across space. This study employs the Cook and Weisberg heteroskedasticity test. The null hypothesis of no heteroskedasticity is rejected at the 99 percent level of confidence.
} 
follows normal, $\sigma$ follows gamma and $\rho$ follows a uniform prior distribution. The prior distribution for the $v_{i}$ terms is independent $\chi^{2}(r) / r$ distribution, where the parameter $r$ is the degrees of freedom in $\chi^{2}$ distribution and chosen by the researcher. These prior distributions are used to provide posterior distributions (similar to updating our prior beliefs), and this is implemented by drawing sequentially from the conditional distributions of these parameters ${ }^{5}$.

Central to the understanding of spatial lag models is the interpretation of the parameter vector $\beta$. In OLS, holding all other variables constant, a change in an explanatory variable $X_{i}$ only affects $y_{i}$. In spatial regression models, a change in an explanatory variable observation can theoretically affect the dependent variable value of all other observations. This requires analyzing how changes in each explanatory variable observation affect all of the dependent variable observations. LeSage and Pace (2009) propose using the average of the direct effects as a scalar summary measure for direct effects and the average of cumulative indirect effects as a summary measure of spatial spillovers arising from changes in explanatory variables. This study follows LeSage and Pace's (2009) interpretation of spatial regression parameters.

\subsection{Dataset}

The study area is located in north-central West Virginia, approximately 70 miles south of Pittsburgh, PA. As of 2000, Monongalia County's population was 81,866 , with a population density of 227 persons per square mile (US Census, 2000). The county has a stable housing market. From 2000 to 2005, the county's population grew by 3.5 percent,

\footnotetext{
${ }^{5}$ The following non-informative prior values are assigned in Bayesian heteroskedastic SAR model estimation: $d=0, v=0$, and $r=4$. This leads to posterior means that are nearly identical to maximum likelihood estimates.
} 
resulting in a housing and commercial development boom. In 2005, Monongalia County produced about 7 percent of the total coal production in West Virginia and ranked seventh among the state's coal producing counties. Monongalia County has a mountainous geography with many hills and valleys. The scarcity of open space results in some residential properties being located close to coal mining areas.

The spatial hedonic price function was estimated using individual single-family residential properties sold in Monongalia County, West Virginia. To increase the number of observations in the sample, this study treats 2004-2005 sales as the same period sales and assumes the characteristics of the houses do not change over the period. Geo-coded parcel data obtained from the Monongalia County Assessor's Office includes structural information on the properties, including the building size, the lot size, the age of the house at the time of sale, the number of bedrooms, the number of bathrooms, whether the house has a full basement, part basement, no basement or crawl space, the presence of a heating system, the presence of a fireplace, and the physical condition of the house (excellent, good, average, fair or poor). The squared terms of the building size, lot size and age are included to capture any non-linear influence these variables may have on house values.

Table 2.2 lists the variable definitions and sources while Table 2.3 presents descriptive statistics for the sample data. Properties that had a nominal sale price of less than $\$ 10,000$ were dropped. Other observations were dropped due to missing data, yielding a total of 683 properties in the dataset. 
Table 2.2: Variable Definitions and Sources

\begin{tabular}{|c|c|c|}
\hline Variable Name & Definition & Source \\
\hline House Price & Sale price of house (logged) & Assessor's Office \\
\hline Building size & $\begin{array}{l}\text { Size of the house in thousands of square } \\
\text { feet }\end{array}$ & Assessor's Office \\
\hline Lot Size & $\begin{array}{l}\text { Size of the lot in tens of thousands of } \\
\text { square feet }\end{array}$ & Assessor's Office \\
\hline Age & Age of house in hundreds of years & Assessor's Office \\
\hline Bedrooms & Number of bedrooms & Assessor's Office \\
\hline Bathrooms & Number of bathrooms & Assessor's Office \\
\hline Full Basement & $1=$ presence of full basement, 0 otherwise & Assessor's Office \\
\hline Part Basement & $\begin{array}{l}1=\text { presence of part basement, } 0 \\
\text { otherwise }\end{array}$ & Assessor's Office \\
\hline No Basement & $\begin{array}{l}1=\text { presence of no basement, } \\
0 \text { otherwise }\end{array}$ & Assessor's Office \\
\hline Crawl Space & excluded dummy & Assessor's Office \\
\hline Heating & $\begin{array}{l}1=\text { presence of heating system, } 0 \\
\text { otherwise }\end{array}$ & Assessor's Office \\
\hline Fireplace & $\begin{array}{l}1=\text { presence of a fireplace, } \\
0 \text { otherwise }\end{array}$ & Assessor's Office \\
\hline Excellent & $\begin{array}{l}1=\text { presence of excellent condition, } 0 \\
\text { otherwise }\end{array}$ & Assessor's Office \\
\hline Good & $\begin{array}{l}1=\text { presence of good condition, } 0 \\
\text { otherwise }\end{array}$ & Assessor's Office \\
\hline Average & $\begin{array}{l}1=\text { presence of average condition, } 0 \\
\text { otherwise }\end{array}$ & Assessor's Office \\
\hline Fair & $\begin{array}{l}1=\text { presence of fair condition, } \\
0 \text { otherwise }\end{array}$ & Assessor's Office \\
\hline Poor & excluded dummy & Assessor's Office \\
\hline Urbanized Area Dummy & $1=$ located in urbanized area, 0 otherwise & $\begin{array}{l}\text { Computed using } 2000 \text { U.S. Census } \\
\text { Data }\end{array}$ \\
\hline Lake Dummy & $\begin{array}{l}1=\text { located within } 0.10 \text { mile of Cheat Lake, } \\
0 \text { otherwise }\end{array}$ & $\begin{array}{l}\text { Computed using Streams Shapefile } \\
\text { form the WV GIS Technical Center }\end{array}$ \\
\hline Median Income & $\begin{array}{l}\text { Census Block level median income in tens } \\
\text { of thousands of dollars }\end{array}$ & $\begin{array}{l}\text { Computed using U.S. Census Block } \\
\text { Group Data (1999 median income) }\end{array}$ \\
\hline White & $\begin{array}{l}\text { Census Block level percent of white } \\
\text { population }\end{array}$ & $\begin{array}{l}\text { Computed using } 2000 \text { U.S. Census } \\
\text { Block Group Data }\end{array}$ \\
\hline College Graduates & $\begin{array}{l}\text { Census Block level percent of population } \\
\text { with a college degree }\end{array}$ & $\begin{array}{l}\text { Computed using } 2000 \text { U.S. Census } \\
\text { Block Group Data }\end{array}$ \\
\hline Poverty & $\begin{array}{l}\text { Census Block level percent of population } \\
\text { below poverty level }\end{array}$ & $\begin{array}{l}\text { Computed using } 2000 \text { U.S. Census } \\
\text { Block Group Data }\end{array}$ \\
\hline Coal Dummy_0.75 & $\begin{array}{l}1=\text { located within } 0.75 \text { mile of a coal mine, } \\
0 \text { otherwise }\end{array}$ & $\begin{array}{l}\text { Computed using Coal Mines Shapefile } \\
\text { from the WV GIS Technical Center }\end{array}$ \\
\hline Coal Dummy_0.75 1.00 & $\begin{array}{l}1=\text { located within } 0.75-1 \text { mile of a coal } \\
\text { mine, } 0 \text { otherwise }\end{array}$ & $\begin{array}{l}\text { Computed using Coal Mines Shapefile } \\
\text { from the WV GIS Technical Center }\end{array}$ \\
\hline Coal Dummy_1.00 1.25 & $\begin{array}{l}1=\text { located within } 1.00-1.25 \text { miles of a coal } \\
\text { mine, } 0 \text { otherwise }\end{array}$ & $\begin{array}{l}\text { Computed using Coal Mines Shapefile } \\
\text { from the WV GIS Technical Center }\end{array}$ \\
\hline Coal Dummy_1.25 1.50 & $\begin{array}{l}1=\text { located within } 1.25-1.50 \text { miles of a coal } \\
\text { mine, } 0 \text { otherwise }\end{array}$ & $\begin{array}{l}\text { Computed using Coal Mines Shapefile } \\
\text { from the WV GIS Technical Center }\end{array}$ \\
\hline
\end{tabular}


Table 2.3: Descriptive Statistics

\begin{tabular}{|c|c|c|c|c|}
\hline Variable & Mean & Std. Dev. & Min & Max \\
\hline House price & $146,274.9$ & $123,139.7$ & 10,000 & $1,139,000$ \\
\hline Building size (1000 sq. ft.) & 1.67 & 0.74 & 0.47 & 5.89 \\
\hline Lot size (10,000 sq. ft.) & 2.90 & 12.26 & 0.00 & 226.21 \\
\hline Age (hundreds) & 0.46 & 0.31 & 0 & 1.64 \\
\hline Bedrooms & 2.89 & 0.79 & 1 & 6 \\
\hline Bathrooms & 1.48 & 0.63 & 0 & 5 \\
\hline Full Basement & 0.61 & 0.49 & 0 & 1 \\
\hline Part Basement & 0.18 & 0.38 & 0 & 1 \\
\hline No Basement & 0.11 & 0.31 & 0 & 1 \\
\hline Crawl Space & 0.10 & 0.29 & 0 & 1 \\
\hline Heating & 0.98 & 0.15 & 0 & 1 \\
\hline Fireplace & 0.20 & 0.40 & 0 & 1 \\
\hline Excellent & 0.43 & 0.49 & 0 & 1 \\
\hline Good & 0.27 & 0.44 & 0 & 1 \\
\hline Average & 0.19 & 0.40 & 0 & 1 \\
\hline Fair & 0.10 & 0.30 & 0 & 1 \\
\hline Poor & 0.01 & 0.11 & 0 & 1 \\
\hline Urbanized Area Dummy & 0.42 & 0.49 & 0 & 1 \\
\hline Lake Dummy & 0.08 & 0.15 & 0 & 1 \\
\hline Median Income $(\$ 10,000)$ & 3.51 & 1.40 & 0.48 & 6.18 \\
\hline White & 0.93 & 0.06 & 0.70 & 0.99 \\
\hline College graduates & 0.31 & 0.13 & 0.05 & 0.52 \\
\hline Poverty & 0.21 & 0.17 & 0.05 & 0.66 \\
\hline Coal Dummy_0.75 & 0.03 & 0.18 & 0 & 1 \\
\hline Coal Dummy_0.75 1.00 & 0.02 & 0.15 & 0 & 1 \\
\hline Coal Dummy_1.00 1.25 & 0.01 & 0.10 & 0 & 1 \\
\hline Coal Dummy_1.25 1.50 & 0.02 & 0.16 & 0 & 1 \\
\hline
\end{tabular}


Included among the neighborhood variables are 2000 U.S. Census Block level median income, percent of white population, percent of college graduates, and percent of population below poverty line. GIS techniques are employed to match the houses with the census block level neighborhood variables. An urbanized area dummy is created to control for urbanized area and big city effects such as public service provision, entertainment and recreational services, zoning, etc. Among important determinants of housing values are the local property tax rates, which are collected by school districts. Since in West Virginia, counties are the school districts, property tax rates are not included in the study. Finally, considering that houses near a natural recreation site may be more expensive, a lake dummy is created to capture the houses located within 0.10 mile of Cheat Lake.

One key piece of data is the polygon coverages of coal mining permit areas, obtained from the West Virginia GIS Technical Center. These are used to identify the coal mining areas in the study area. This study uses truncated data on coal mining permit areas. Data include only the coal mining permit areas in West Virginia and ignore the coal mining areas in the neighboring state Pennsylvania, since the coal mining areas in the neighboring state are not near the West Virginia border.

The geo-coded coal mining permit areas in West Virginia include current coal mining areas as well as historical mining areas. Considering that a coal mine that became inactive half a century ago would have less influence on the property values compared with currently operating coal mines, the study employs GIS techniques to include only coal mines that were active during the sample period. Comprised among the coal mining areas are the underground mining areas, surface mining areas and quarries. The permit 
areas for underground mines do not represent the full extent of underground workings. They only represent areas of surface disturbance such as entry portals and ventilation shafts.

Being located near a coal mine is expected to be associated with lower house prices. Rather than using a distance to nearest coal mine variable to capture this effect, this study chooses to use buffer dummies to control for houses located near coal mines. Unlike other variables, using a distance variable in spatial regressions causes parameter interpretation problems. The partial derivative of the hedonic function with respect to the distance variable accounts for the effect of a change in distance, holding all other variables, including the characteristics of the neighboring houses, constant. Given that it is not possible to change distance while holding neighboring house characteristics constant, this problem is addressed by using buffer dummy variables.

With housing and coal mines data spatially linked in GIS, parcel centroids and buffer dummies are created. First, $3 / 4$ mile buffer is applied to capture the impact on houses that are in close proximity to a coal mine. Then, quarter-mile increments are used to capture any distance decay effect. These yield four buffers variables. There are a total of 23 sold properties within $3 / 4$ mile of a coal mine, 16 between $3 / 4$ to 1 mile, 7 between 1 to $1 \frac{1 / 4}{4}$ miles and 17 between $1 \frac{1 / 4}{4}$ to $1 \frac{1}{2}$ miles $^{6}$. Figure 2.1 maps the parcel centroids, Figure 2.2 maps the active coal mines, and Figure 2.3 displays both the parcel centroids and the coal mines on the same map.

\footnotetext{
${ }^{6} 1$ mile and 1-1.5 miles buffer dummies are created for robustness tests. The results do not contradict the study findings.
} 
Figure 2.1: House Sales in the Study Area

\section{Residential Property Sales in Monongalia County, West Virginia}
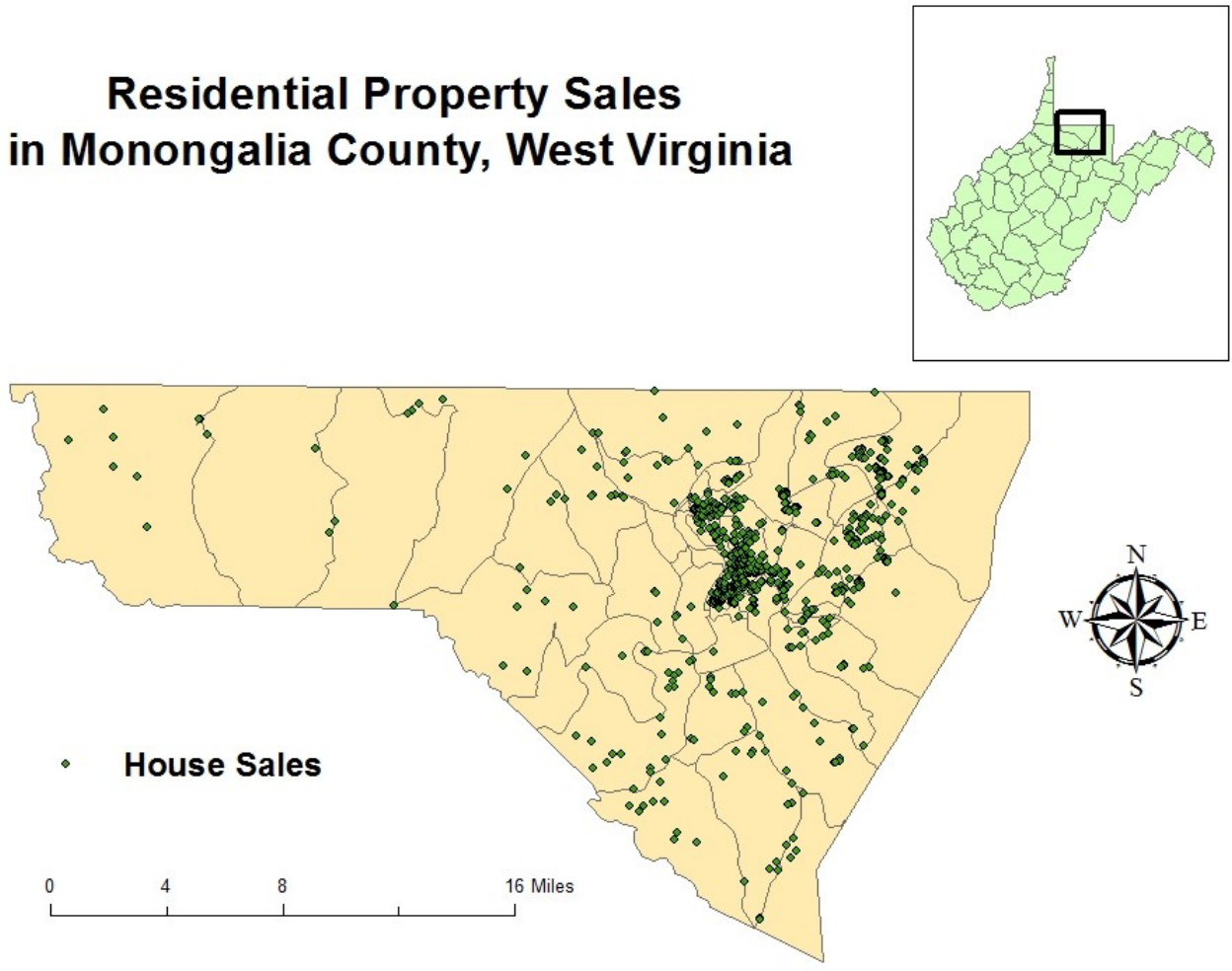
Figure 2.2: Active Coal Mines in the Study Area

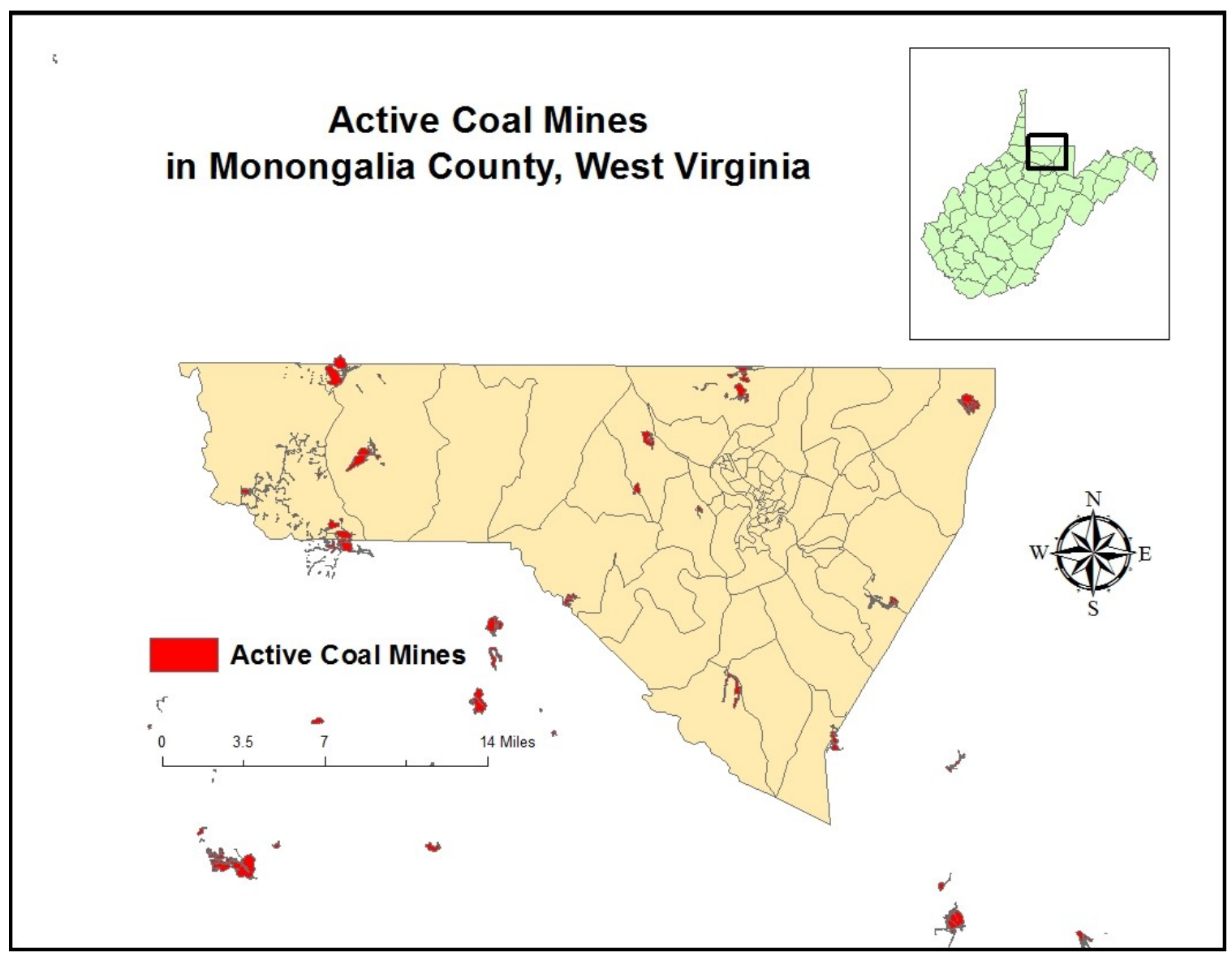


Figure 2.3: House Sales and Active Coal Mines in the Study Area

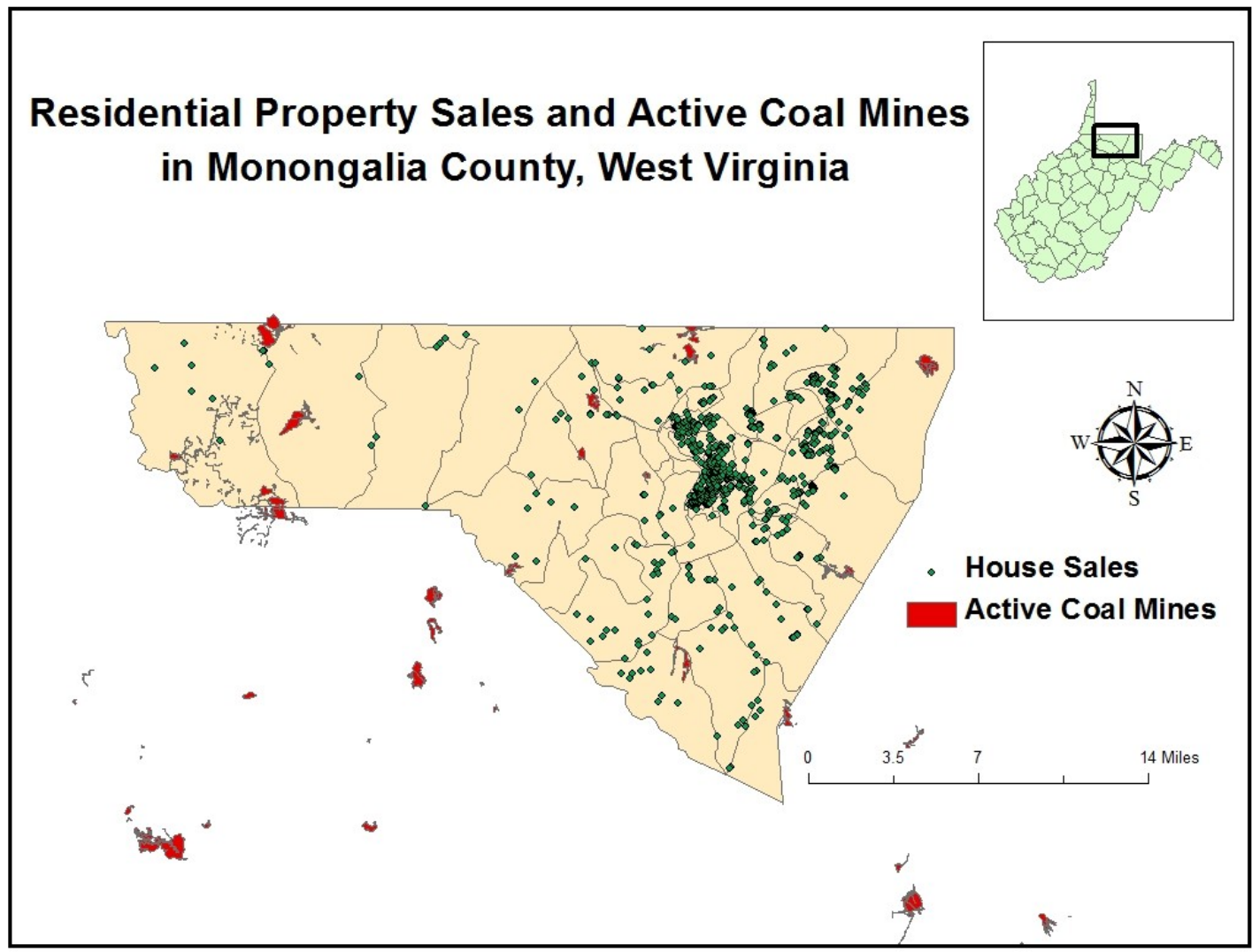

\subsection{Results}

A Bayesian Monte Carlo Markov Chain (MCMC) estimation procedure involving 5,000 draws is used to calculate standard deviations from the posterior distribution of the effects estimates. These are used to construct an associated t-statistic and marginal probability or p-level to draw inferences for significance. Direct, indirect, and total effects estimates are presented in Table 2.4. 
Table 2.4: Direct, Indirect, and Total Effects Estimates

\begin{tabular}{|c|c|c|c|}
\hline Variable & Direct Effects & $\begin{array}{r}\text { Indirect } \\
\text { Effects }\end{array}$ & Total Effects \\
\hline Coal Dummy_0.75 & $\begin{array}{l}-0.154 * * * \\
(0.00)\end{array}$ & $\begin{array}{l}-0.008 * * * \\
(0.00)\end{array}$ & $\begin{array}{c}-0.162 * * * \\
(0.00)\end{array}$ \\
\hline Coal Dummy_0.75 1.00 & $\begin{array}{l}-0.105^{* * *} \\
(0.00)\end{array}$ & $\begin{array}{l}-0.005^{* *} \\
(0.02)\end{array}$ & $\begin{array}{c}-0.110^{* *} \\
(0.02)\end{array}$ \\
\hline Coal Dummy_1.00 1.25 & $\begin{array}{c}-0.093 * * \\
(0.01)\end{array}$ & $\begin{array}{c}-0.005^{* *} \\
(0.03)\end{array}$ & $\begin{array}{c}-0.099 * * \\
(0.01)\end{array}$ \\
\hline Coal Dummy_1.25 1.50 & $\begin{array}{r}-0.020 \\
(0.57)\end{array}$ & $\begin{array}{r}-0.001 \\
(0.62)\end{array}$ & $\begin{array}{r}-0.021 \\
(0.57)\end{array}$ \\
\hline Building size & $\begin{array}{l}0.214^{* * *} \\
(0.00)\end{array}$ & $\begin{array}{l}0.011 * \\
(0.06)\end{array}$ & $\begin{array}{l}0.225^{* * *} \\
(0.00)\end{array}$ \\
\hline Building size squared & $\begin{array}{l}-0.020 * * * \\
(0.00)\end{array}$ & $\begin{array}{c}-0.001 * \\
(0.09)\end{array}$ & $\begin{array}{l}-0.021 * * * \\
(0.00)\end{array}$ \\
\hline Lot size & $\begin{array}{l}0.004^{* *} \\
(0.03)\end{array}$ & $\begin{array}{l}0.000 \\
(0.17)\end{array}$ & $\begin{array}{l}0.004 * * \\
(0.03)\end{array}$ \\
\hline Lot size squared & $\begin{array}{r}-0.000 \\
(0.18)\end{array}$ & $\begin{array}{r}-0.000 \\
(0.30)\end{array}$ & $\begin{array}{r}-0.000 \\
(0.18)\end{array}$ \\
\hline Age & $\begin{array}{l}-0.105 \\
(0.16)\end{array}$ & $\begin{array}{r}-0.005 \\
(0.30)\end{array}$ & $\begin{array}{r}-0.110 \\
(0.17)\end{array}$ \\
\hline Age squared & $\begin{array}{l}0.028 \\
(0.67)\end{array}$ & $\begin{array}{l}0.001 \\
(0.71)\end{array}$ & $\begin{array}{l}0.075 \\
(0.36)\end{array}$ \\
\hline Excellent Condition & $\begin{array}{l}0.459 * * * \\
(0.00)\end{array}$ & $\begin{array}{l}0.023 * \\
(0.06)\end{array}$ & $\begin{array}{l}0.482^{* * *} \\
(0.00)\end{array}$ \\
\hline Good Condition & $\begin{array}{l}0.337 * * * \\
(0.00)\end{array}$ & $\begin{array}{l}0.017 * \\
(0.08)\end{array}$ & $\begin{array}{l}0.355^{* * * *} \\
(0.00)\end{array}$ \\
\hline Average Condition & $\begin{array}{l}0.249 * * * \\
(0.00)\end{array}$ & $\begin{array}{l}0.013 \\
(0.11)\end{array}$ & $\begin{array}{l}0.262^{* * * *} \\
(0.00)\end{array}$ \\
\hline Fair Condition & $\begin{array}{c}-0.026 \\
(0.75)\end{array}$ & $\begin{array}{r}-0.001 \\
(0.78)\end{array}$ & $\begin{array}{r}-0.027 \\
(0.75)\end{array}$ \\
\hline Bedrooms & $\begin{array}{l}0.010 \\
(0.30)\end{array}$ & $\begin{array}{r}0.000 \\
(0.39)\end{array}$ & $\begin{array}{l}0.010 \\
(0.30)\end{array}$ \\
\hline Bathrooms & $\begin{array}{l}0.029 * * \\
(0.01)\end{array}$ & $\begin{array}{l}0.001 \\
(0.14)\end{array}$ & $\begin{array}{l}0.030 * * \\
(0.01)\end{array}$ \\
\hline Heating & $\begin{array}{l}0.044 \\
(0.33)\end{array}$ & $\begin{array}{l}0.002 \\
(0.43)\end{array}$ & $\begin{array}{l}0.046 \\
(0.33)\end{array}$ \\
\hline Fireplace & $\begin{array}{l}0.028 * \\
(0.06)\end{array}$ & $\begin{array}{l}0.001 \\
(0.19)\end{array}$ & $\begin{array}{l}0.028 * \\
(0.06)\end{array}$ \\
\hline Full Basement & $\begin{array}{r}-0.010 \\
(0.62)\end{array}$ & $\begin{array}{r}-0.000 \\
(0.66)\end{array}$ & $\begin{array}{r}-0.011 \\
(0.62)\end{array}$ \\
\hline Part Basement & $\begin{array}{r}-0.004 \\
(0.86)\end{array}$ & $\begin{array}{l}0.000 \\
(0.88)\end{array}$ & $\begin{array}{r}-0.004 \\
(0.86)\end{array}$ \\
\hline No Basement & $\begin{array}{l}0.049 * \\
(0.06)\end{array}$ & $\begin{array}{l}0.003 \\
(0.20)\end{array}$ & $\begin{array}{l}0.052 * \\
(0.06)\end{array}$ \\
\hline Urbanized Area Dummy & $\begin{array}{l}0.058 * * * \\
(0.00)\end{array}$ & $\begin{array}{l}0.003 \\
(0.10)\end{array}$ & $\begin{array}{l}0.061^{* * *} \\
(0.00)\end{array}$ \\
\hline Lake Dummy & $\begin{array}{l}0.102^{* * *} \\
(0.00)\end{array}$ & $\begin{array}{l}0.020 * * * \\
(0.00)\end{array}$ & $\begin{array}{l}0.122^{* * *} \\
(0.00)\end{array}$ \\
\hline Median Income & $\begin{array}{r}-0.004 \\
(0.54)\end{array}$ & $\begin{array}{r}-0.000 \\
(0.60)\end{array}$ & $\begin{array}{r}-0.005 \\
(0.54)\end{array}$ \\
\hline White & $\begin{array}{l}0.074 \\
(0.62)\end{array}$ & $\begin{array}{l}0.004 \\
(0.66)\end{array}$ & $\begin{array}{l}0.078 \\
(0.62)\end{array}$ \\
\hline College Graduates & $\begin{array}{r}-0.030 \\
(0.66)\end{array}$ & $\begin{array}{r}-0.001 \\
(0.72)\end{array}$ & $\begin{array}{r}-0.032 \\
(0.66)\end{array}$ \\
\hline
\end{tabular}




\begin{tabular}{lccc} 
Poverty & -0.036 & -0.002 & -0.036 \\
R-squared & $(0.56)$ & $(0.63)$ & $(0.56)$ \\
$\boldsymbol{\rho}$ & 0.50 & & \\
& $0.21^{* * *}$ & & \\
\hline
\end{tabular}

Table Notes: Numbers in parentheses are p-values based on heteroskedasticity-consistent standard errors, and $* * *, * *$, and $*$ represent statistical significance at the $99 \%, 95 \%$, and $90 \%$ level, respectively.

The variables of focus in this study are the coal mine buffer variables. The model predicts that a negative buffer variable estimate is associated with disamenity characteristics of close proximity to coal mines since the parameter implies lower house prices at the mean, all else constant. On the other hand, a positive estimate points to amenity impacts of coal mines. The results support the disamenity impacts of coal mines, even after controlling for neighborhood variables. The direct effects estimates show the average percentage increase in house sales prices resulting from a one unit change in various house-specific explanatory variable characteristics. In particular, the direct effect of being located within $3 / 4$ mile of a coal mine is estimated as -0.15 , implying that at the mean, being located close to a coal mine reduces own-house price by 15 percent, all else constant. Purchasing a house located farther from a coal mine is associated with a lower discount. All else constant, houses located within $3 / 4-1$ mile and $1-1 \frac{1}{4}$ miles of a coal mine experience 11 percent and 10 percent lower average own-house prices respectively. Beyond 1 1 $\frac{1}{4}$ miles, the proximity effects are no longer significant.

Among the variables found to be significant in influencing house prices are house condition variables, building size, lot size, number of bathrooms, the presence of a fireplace, the urbanized area, and the lake dummies. In Table 4, the direct effect magnitude of 0.46 for the excellent house condition implies that the mean house sales price is 46 percent higher compared with a house in poor condition, all else constant. 
Building size is another important factor influencing house prices. A direct effect magnitude of 0.21 implies that a thousand square feet increase in house size results in 21 percent increase in average house sales prices. Type of basement, number of bedrooms, the presence of a heating system, and neighborhood variables fail to explain the variation in house prices.

Indirect effects estimates presented in the above table represent spatial spillovers and capture neighboring-house effects associated with changes in own-house level characteristics. LeSage and Pace (2009) explain that indirect effects estimates can be interpreted in two different ways. The first interpretation is named as the average total impact on an observation. This interpretation captures how a change in the ownexplanatory variable characteristics of all houses by some constant amount would change the price of a typical house. The second interpretation is named as the average total impact from an observation, which captures the cumulative impact of a change in ownhouse explanatory variable characteristics averaged over all other houses.

Positive indirect effect estimates are indicative of positive spatial externalities, whereas negative estimates can be considered as negative spatial externalities. Using the second interpretation, the indirect impact magnitude of -0.008 points to negative spillover effects of being located within $3 / 4$ mile of a coal mine on neighboring-house prices. The impact estimates for spillover effects associated with houses near coal mines disappear beyond 11/4 miles. House condition variables and building size are significant sources of positive spillovers. For instance, compared with a house in poor condition, an excellent condition of own-house increases the sales price of neighboring houses by 2 percent. 
Total effects, which is the sum of direct and indirect effects, capture both ownhouse and feedback effects resulting from a change in own-house specific characteristics. Coal buffer variables are significant until 1/1/4 miles. A total effects magnitude of -0.16 implies that houses within $3 / 4$ mile of a coal mine sell for 16 percent less. The total effects estimates decrease in magnitude with distance from coal mines. Houses within $3 / 4$ to 1 mile of a coal mine are associated with 11 percent lower prices, while houses within the next quarter mile experience 10 percent discount. Negative impact of coal mines is lost within the next quarter mile.

House condition variables and building size are other variables that exert both significant positive direct effects and positive spillover effects. For instance, compared to a house in poor condition, an excellent condition of own-house increases the sales price of own-house by 48 percent after accounting for feedback effects, while a good and an average condition results in an increase of 36 percent and 26 percent respectively.

Following Kim, Phipps, and Anselin (2003), marginal willingness to pay (MWTP) is calculated for the coal buffer variables. The marginal implicit price of each variable is the corresponding total effects estimate in the hedonic price function, assuming the housing market is in equilibrium. The mean MWTP for the first specification can be formulated as:

$$
\text { Mean MWTP }=\beta_{C D_{0.75}}\left(\frac{1}{1-\rho}\right) \bar{y}
$$

where $\beta$ coefficient is the total effect estimate of the Coal Dummy_0.75 variable, $\rho$ is the spatial-lag coefficient, and y-bar $(\$ 146,275)$ is the mean value of the house prices. 
MWTP calculations reveal that an average home buyer would be willing to pay $\$ 29,723$ less to buy a house located within $3 / 4$ mile of a coal mine, $\$ 20,367$ less to live within $3 / 4$ to 1 mile of a coal mine, and $\$ 18,516$ less to live within the next quarter of a mile.

\subsection{Conclusions and Implications}

This paper examines the impact of proximity to a coal mine on single-family residential property values. Properties near coal mines often suffer from dust and noise pollution, and sometimes explosions. Whether real or perceived, they also suffer from the risk of land subsidence. Coal community residents often face higher risks of chronic heart, kidney, and lung diseases that are connected to coal pollution. Since many of the costs associated with coal mining are clustered in the immediate environment, their presence can cause property values to decline. However, no empirical studies have provided evidence to support or reject this claim. This study fills this gap by directly assessing the impact of a coal mine on housing values.

A spatial hedonic price model is estimated to measure the price differential between single-family homes located in close proximity to a coal mine and those with similar attributes but located at a distance from the coal mine. The recent advancements in spatial econometric techniques are used to allow for separate estimation of direct, indirect (i.e., spillover), and total effects of proximity to a coal mine on property values. The results indicate that proximity to a coal mine translates negatively into property values with a negative distance gradient. On the average, houses located within $3 / 4$ mile of a coal mine sell at a 16 percent discount. Houses located within $3 / 4$ to 1 mile sell for 11 percent less, while houses located within the next quarter of a mile sell for 10 percent 
less. Proximity effects disappear beyond 11/4 miles. Proximity to coal mines is associated with both significant negative direct effects on own-house value and negative spillover effects on neighboring house values. These results reinforce previous hedonic analyses of environmental hazards that find a significant negative impact on house values.

The study also includes structural house characteristics and neighborhood variables. Factors that are found to impose both significant positive direct effects and positive spillover effects are house condition variables, the building size, and the lake dummy. One result of interest is that neighborhood variables do not affect property values.

The findings of this study facilitate a better understanding of the costs coal mines impose on surrounding housing market. Results support homeowners' concern that proximity to a coal mine adversely affects property values. Any future cost-benefit analyses of coal mines should also consider discounted house values. 


\section{Chapter 3}

\section{U.S. County Growth: A Bayesian Model \\ Averaging Approach}




\subsection{Introduction}

Regional economic growth has long interested researchers, resulting with an extensive literature examining the prominent factors of economic growth. However, growth theories partially specify the important factors that underlie the data-generating process for growth regressions. When faced with model uncertainty, researchers often introduce a large set of variables and try to identify the important factors. As argued by Levine and Renelt (1992), Pack (1994), Sala-i-Martin (1997), Schultz (1999), Durlauf and Quah (1999), Fernandez, Ley and Steel (2001a), Brock and Durlauf (2001), Barro (2007), and LeSage and Fischer (2008), the lack of theoretical insights in the growth literature results with studies that document the correlation of several variables with growth. However, using a large set of variables increases the dispersion of estimated coefficients and complicates the identification of prominent factors.

Another complication in growth regressions can arise with the introduction of spatial dependence, which adds the uncertainty pertaining to the use of an appropriate spatial weight matrix that describes the structure of the spatial dependence between regions. Spatial growth regression models produce estimates and inferences that are conditional on both the particular weight matrix used to specify the spatial dependence and the explanatory variables included in the growth regression. Using different spatial weight matrices may change the dispersion of estimated coefficients, further complicating the identification of important growth factors.

Another source of model uncertainty can arise from the use of an appropriate spatial regression specification. Traditionally, the models used to account for spatial dependence are the spatial autoregressive (SAR), the spatial error model (SEM), and the 
spatial Durbin model (SDM). The SAR model consists of a spatial lag of the dependent variable, whereas the SEM corrects for spatial correlation in the disturbance term. The SDM includes spatial lags of the explanatory variables as well as the spatial lag of the dependent variable. Selection of an appropriate specification is central to the analysis of spatial growth regressions.

A recently developed Markov Chain Monte Carlo model composition $\left(\mathrm{MC}^{3}\right)$ with Bayesian model averaging framework can accommodate model uncertainty regarding the explanatory variables and the spatial weight matrix employed (LeSage and Fischer, 2008). The results of Bayesian model averaging report models with their posterior model probabilities and the probability that each variable should enter the model based on their frequency of appearance in the top 1,000 models (top number of models is chosen by the researchers). The Bayesian solution to model uncertainty weighs the estimates from each model by their posterior model probability. It reports a linear combination of estimates from more than one model, producing model averaged estimates. Inferences based on model averaged estimates would embody model uncertainty, since these reflect estimates that arise from different models with different weight matrices and different explanatory variables. This contrasts with the conventional methods that can underestimate dispersion in estimates, since these methods condition on a single selected model and ignore model uncertainty.

This study fills the gap in the regional growth literature by applying $\mathrm{MC}^{3}$ with the Bayesian model averaging methodology on a sample of U.S. counties, to deal with model uncertainty in spatial growth regressions. First, growth regression estimates using two different spatial weights matrix specifications, first-order contiguity (borders-touching) 
and optimal nearest neighbors, are reported to demonstrate how different weight matrix specifications may lead to ambiguous results in spatial county growth regressions. Later, Bayesian model averaging is employed to produce model averaged estimates and inferences that would embody model uncertainty.

Section 3.2 summarizes the literature on county level growth studies, section 3.3 describes the methodology and data, section 3.4 discusses results, and section 3.5 concludes.

\subsection{Literature Review}

A number of studies at the U.S. county level have analyzed the determinants of economic growth, but failed to employ appropriate spatial econometrics techniques (Carlino and Mills, 1987; Higgins et al., 2006; Young et al., 2008; Levernier et al., 2000, Deller and Lledo, 2007). These studies typically employ neoclassical growth theory and do not account for the spatial dependence among counties. Unlike previous research, this study accounts for the spatial spillover effects that arise from changes in own-county characteristics.

An extensive amount of scholarship surrounds Bayesian model comparison for non-spatial regression models. These studies typically compare models with different explanatory variables matrices (Zellner, 1971; Fernandez et al., 2001a, 2001b; Madigan and York, 1995; Raftery, 1995; Raftery et al., 1997; Hoeting et al., 1999; Denison et al., 1998, Deller and Lledo, 2007). LeSage and Parent (2007) extend the literature on Bayesian model comparison for OLS regression models to include spatial autoregressive 
and spatial error models. They compare models with alternative explanatory variables matrices conditional on a single fixed spatial weight matrix.

Most central to this paper is the study by LeSage and Fischer (2008). They contribute to the regional growth literature in a number of ways. They first clarify the issue of growth model specification by demonstrating that in the presence of an omitted variable, that is correlated with an included variable, spatial dependence in the disturbances of an OLS regression leads to a Spatial Durbin Model (SDM) ${ }^{7}$. They also extend LeSage and Parent's (2007) $\mathrm{MC}^{3}$ approach to include spatial Durbin models and allow simultaneous comparison of models based on both alternative spatial weight matrices and explanatory variables.

\subsection{Methodology and Data}

\subsubsection{Methodology}

\subsubsection{Spatial Growth Regression Models}

Following an extensive review of the empirical literature on growth regression studies, Abreu et al. (2004) identify spatial autoregressive and spatial error models as more prevalent in growth regressions. They also stress that the key finding in the growth literature is the spatial dependence between per capita income levels, employment and population variables among regions. It also seems plausible that difficult to quantify or unobservable characteristics may exhibit spatial dependence and be correlated with one or more included variable. For instance, a hard to quantify variable, physical capital, is often ignored in regressions, whereas human capital is often included by using some

\footnotetext{
${ }^{7}$ See LeSage and Fischer (2008) for details regarding SDM derivation in growth models.
} 
measure of educational attainment. Physical and human capital are likely to be correlated and exhibit spatial dependence.

A general Spatial Durbin Model for a growth regression can be formulated as follows:

$$
y=\rho W y+\alpha \imath+X \beta+W X \theta+\varepsilon
$$

where $y$ represents income growth rates, $\mathrm{X}$ is a vector of explanatory variables affecting growth rates and $l$ is the intercept vector. $W$ is an $n x n$ non-negative spatial weight matrix, defining spatial dependence among observations. The elements of $W$ take a positive value if an observation in region $i$ is related to an observation in region $j$, and zero otherwise. The matrix is normalized to have row sums of one, which enables the spatial lag $W y$ to be expressed as a linear combination of growth rates of related regions. The scalar parameter $\rho$ provides a measure of average influence of related regions' growth rates on own-region growth rates. In spatial growth regressions, $\rho$ is expected to have a positive value of less than one, indicating that own-region growth rates are positively related to a linear combination of related regions' growth rates. $W X$ is a linear combination of explanatory variables from related regions and includes initial period values of explanatory variables. Initial period values serve to avoid endogeneity and model initial regional attributes as endowments that affect future regional growth. $\varepsilon$ is the error term assumed to be normally distributed with a mean of zero and constant variance.

LeSage and Fischer (2008) introduce the specific functional form that should be employed in spatial growth regressions. A non-spatial growth regression (2), in which 
economic growth between time $t=0$ and $t=T$ is a function of (logged) initial income and a vector of structural characteristics of the economy would look as follows:

$$
\begin{aligned}
& {\left[\ln \left(y_{t}\right)-\ln \left(y_{0}\right)\right] / T=\phi \ln \left(y_{0}\right)+X_{0} \beta+\varepsilon_{t}} \\
& \ln \left(y_{t}\right)=(1+T \phi) \ln \left(y_{0}\right)+T X_{0} \beta+T \varepsilon_{t}
\end{aligned}
$$

Assuming that regional growth rates are spatially dependent due to omitted variables, the SDM generalization of the model is formulated as ${ }^{8}$ :

$$
\begin{aligned}
& \left(I_{n}-\rho W\right)\left[\ln \left(y_{t}\right)\right]-\ln \left(y_{0}\right) / T=\phi \ln \left(y_{0}\right)+X_{0} \beta_{1}+W X_{0} \beta_{2}+\varepsilon_{t} \\
& \left(I_{n}-\rho W\right) \ln \left(y_{t}\right)=(1+T \phi) \ln \left(y_{0}\right)-\rho W \ln \left(y_{0}\right)+T X_{0} \beta_{1}+T W X_{0} \beta_{2}+T \varepsilon_{t} \\
& \ln \left(y_{t}\right)=\rho W \ln \left(y_{t}\right)+(1+T \phi) \ln \left(y_{0}\right)-\rho W \ln \left(y_{0}\right)+T X_{0} B_{1}+T W X_{0} \beta_{2}+T \varepsilon_{t}
\end{aligned}
$$

Equation (4) is the Spatial Durbin Model, where the dependent variable is no longer a growth rate, but regional income level instead. The explanatory variables include initial income levels, initial levels of explanatory variables, and spatial lags of initial levels of income and explanatory variables. Unlike non-spatial growth models, the SDM accounts for the characteristics of related regions as denoted by $W X_{0}$ and the level of spatial dependence $\rho$ and connectivity structure reflected by the weight matrix.

Of crucial importance is parameter interpretation of the spatial Durbin growth model. Unlike non-spatial models, a change in an explanatory variable in region $i$ affects growth in region $i$ as well as growth in other regions. The first effect is called the direct

\footnotetext{
${ }^{8}$ See LeSage and Fischer (2008) for details on SDM generalization of growth models.
} 
effect while the latter is the indirect effect. Theoretically, a change in an explanatory variable observation can affect all of the dependent variable observations. LeSage and Pace (2009) address this problem by using average of the direct effects as a scalar summary measure for direct effects arising from changes in own explanatory variables and the average of cumulative indirect effects as a summary measure of spatial spillovers arising from changes in own explanatory variables ${ }^{9}$.

The choice of weight matrix, which defines the connectivity between regions, is one important aspect of spatial growth regressions. Different spatial weight matrices may change the dispersion of estimated coefficients, leading to ambiguous results. This study will first report results obtained by employing two different weight matrix specifications on a sample of U.S. counties. This will demonstrate the ambiguous results to which different weight matrix specifications lead in county economic growth regressions. Later, Bayesian model averaging will be employed to determine the determinants of county economic growth.

The first weight matrix specification, first-order contiguity (borders touching), follows the conventional approach of defining regions as neighbors with a common border. The second weight matrix specification is the optimal nearest neighbors. Following the Bayesian model comparison defined in Lesage and Pace (2009), first the SAR models with different number of nearest neighbors weight matrix specifications (1 to 15 nearest neighbors) are run against each other ${ }^{10}$. The winner is the SAR model with 8 nearest neighbors. Next, the same procedure is implemented on the SEM and the SDM specifications. The SEM with 7 nearest neighbors and the SDM with 14 nearest

\footnotetext{
${ }^{9}$ See LeSage and Pace (2009) for details on spatial model parameter interpretation.

${ }^{10}$ See LeSage and Pace (2009) for details on Bayesian model selection for different model specifications and different weight matrices.
} 
neighbors are the winning model specifications. Finally, the winners of the above process; the SAR model with 8 nearest neighbors, the SEM with 7 nearest neighbors, and the SDM with 14 nearest neighbors specifications are run against each other. The model specification that has the highest probability of describing the data is found as the SDM with an optimal number of 14 nearest neighbors. When run against each other, the SDM model with a spatial weight matrix of 14 nearest neighbors produces a probability of 1 , whereas the other models with different neighbor specifications result in probabilities of zero. A summary of the results for different model specifications is provided in Table 3.1.

Table 3.1: Summary Results for Bayesian Model Selection

\begin{tabular}{cccc}
\hline \multirow{2}{*}{$\begin{array}{c}\text { Number of Nearest } \\
\text { Neighbors }\end{array}$} & SAR & SEM & SDM \\
$\mathbf{1}$ & & & \\
$\mathbf{2}$ & 0.10 & 0.00 & 0.00 \\
$\mathbf{3}$ & 0.00 & 0.00 & 0.00 \\
$\mathbf{4}$ & 0.00 & 0.00 & 0.00 \\
$\mathbf{5}$ & 0.00 & 0.00 & 0.00 \\
$\mathbf{6}$ & 0.00 & 0.04 & 0.00 \\
$\mathbf{7}$ & 0.00 & 0.06 & 0.00 \\
$\mathbf{8}$ & 0.05 & $\mathbf{0 . 9 0}$ & 0.00 \\
$\mathbf{9}$ & $\mathbf{0 . 8 5}$ & 0.00 & 0.00 \\
$\mathbf{1 0}$ & 0.06 & 0.00 & 0.00 \\
$\mathbf{1 1}$ & 0.04 & 0.00 & 0.00 \\
$\mathbf{1 2}$ & 0.00 & 0.00 & 0.00 \\
$\mathbf{1 3}$ & 0.00 & 0.00 & 0.02 \\
$\mathbf{1 4}$ & 0.00 & 0.00 & 0.03 \\
$\mathbf{1 5}$ & 0.00 & 0.00 & $\mathbf{0 . 9 5}$ \\
& 0.00 & 0.00 & 0.00 \\
Final Run & & & \\
\hline
\end{tabular}

Next, the Bayesian heteroskedastic SDM estimation procedure described in LeSage and Pace (2009) is employed ${ }^{11}$. Bayesian estimation allows for non-constant variance across space as well as outliers. When a particular region follows a different relationship from that of the majority of spatial observations, the error terms are no

\footnotetext{
${ }^{11}$ Heteroskedasticity tests suggest non-constant variance.
} 
longer normal, but more likely to follow a Student-t distribution. A set of variance scalars $\left(v_{1}, \ldots, v_{n}\right)$ as unknown parameters to be estimated are introduced, allowing the assumption of non-constant variance across space. Accordingly, unit estimates of $v_{i}$ would be indicative of constant variance, whereas large estimates of $v_{i}$ would be indicative of heteroskedasticity or outliers. Large $v_{i}$ values handle outliers or observations with large variances by downweighting these observations.

The Bayesian heteroskedastic SDM is specified as follows:

$$
\begin{aligned}
& y=\rho W y+\alpha \imath+X \beta+W X \theta+\varepsilon \\
& \varepsilon \sim N\left(0, \sigma^{2} V\right) \quad V=\operatorname{diag}\left(v_{1}, \ldots, v_{n}\right) \\
& \pi(\beta) \sim N(c, T) \\
& \pi\left(r / v_{i}\right) \sim \operatorname{iid} \chi^{2}(r) \\
& \pi\left(1 / \sigma^{2}\right) \sim \Gamma(d, v) \\
& \pi(\rho) \sim U[-1,1]
\end{aligned}
$$

The prior distributions are indicated by $\pi$. $\beta$ follows normal, $\sigma$ follows gamma and $\rho$ follows a uniform prior distribution. The prior distribution for the $v_{i}$ terms is independent $\chi^{2}(r) / r$ distribution, where the parameter $r$ is the degrees of freedom in $\chi^{2}$ distribution and chosen by the researcher. The parameters $\beta, V$ and $\sigma$ in the heteroskedastic SDM can be estimated by drawing sequentially from the conditional distributions of these parameters ${ }^{12}$.

\footnotetext{
${ }^{12}$ The following non-informative prior values are assigned in Bayesian heteroskedastic SDM estimation: $d=0, v=0$, and $r=4$.
} 
Table 3.4 reports results with the first-order contiguity (county borders touching) weight matrix, while Table 3.5 reports results using fourteen nearest neighbors. The ambiguous results of these spatial county growth regressions are discussed in section 3.4.

\subsubsection{Bayesian Model Averaging}

Following LeSage and Fischer (2008), SDM is specified for Bayesian model comparison as:

$$
y=\alpha \imath+\rho W(h, d) y+X B+W(h, d) X \theta+\varepsilon
$$

where $W$ is the spatial weight matrix, $h$ is the number of nearest neighbors used to construct the weight matrix and $d$ is the type of spatial weight matrix. The types of spatial weight matrix can be based on great circle distances between regions.

Prior probabilities, $\pi\left(M_{i}\right), i=1, \ldots, m$ for each of the $\mathrm{m}$ different models, $\mathrm{M}=$ $\mathrm{M}_{1}, \mathrm{M}_{2}, \ldots, \mathrm{M}_{\mathrm{m}}$ and prior distributions for the parameters $\pi(\eta)$, where $\eta=(\rho, \alpha, \beta, \theta, \sigma$,

$\mathrm{h}, \mathrm{d}$ ) are assigned. The prior distribution of $h$ (such as between 1 and 15), defines the range of nearest number of neighbors in the weight matrix.

Since the sample data determines posterior model probabilities, setting the prior probabilities equal to $1 / m$, makes each model equally likely a priori. These are combined with the likelihood for $y$ conditional on $\eta$ and the models $\mathrm{M}$, which is shown as $p(y \backslash \eta, M)$. The joint probability for $M, \eta$ and $y$ is:

$$
p(M, \eta, y)=\pi(M) \pi(\eta \backslash M) p(y \backslash \eta, M)
$$


The joint posterior distribution for models and parameters, given data is:

$$
p(M, \eta \backslash y)=\frac{\pi(M) \pi(\eta \backslash M) p(y \backslash \eta, M)}{p(y)}
$$

The posterior probabilities regarding the models are:

$$
p(M \backslash y)=p(M, \eta \backslash y) d \eta
$$

Expression (8) requires integrating over the parameter vector $\eta$. Lesage and Parent (2007) develop expressions for the marginal posterior in (8) for the spatial Durbin model, for the case of fixed parameters $h$ (number of neighbors used in the weight matrix) and $d$ (type of weight matrix). LeSage and Fischer (2008) extend Lesage and Parent's (2007) log-marginal likelihood for a given model to condition on $d$ and $h$. This implies an additional integration over the parameters $d$ and $h$, which take on a discrete number of values:

$$
\begin{aligned}
& p(M \backslash y)=\iint_{d} \int_{h} p^{*}(M, \rho, h \backslash j) d \rho, d h, d d \\
& p^{*}(M, \rho, h, d \backslash j)=\int_{\eta} p(M, \alpha, \beta, \theta, \sigma, \rho, h, d \backslash y) d \eta
\end{aligned}
$$

LeSage and Parent (2007) show how the $\mathrm{MC}^{3}$ method can be used to move a Markov Chain Monte Carlo sampler through a potentially large model space to sample 
regions of high posteriors. This eliminates the need to consider all possible models. The constructed sampler explores relevant parts of the very large model space. Let $\mathrm{M}$ be the current model state. An extended notion of model neighborhood involves models containing the same type of weight matrix, with one more neighbor, or one less neighbor. Using the following model acceptance probability, proposed model $M^{\prime}$ is compared to current model state M.

$$
\min \left[1, \frac{p\left(M^{\prime} \backslash y\right)}{p(M \backslash y)}\right]
$$

LeSage and Parent (2007) describe the implementation of univariate numerical integration methods to construct a Metropolis-Hastings sampling schema that enables the $\mathrm{MC}^{3}$ method. A vector of the log-marginal values for the current model $\mathrm{M}$ and proposed model $M$ ' are stored during sampling. Then these are scaled and integrated to produce the ratio $p\left(M^{\prime} \backslash y\right) / p(M \backslash y)$ in (10) to determine acceptance or rejection of the proposed model.

\subsubsection{Data}

The data used in this study are gathered from several sources, but the majority comes from the 1980 U.S. Census. The data contain 3035 county-level observations. Per capita personal income data are from the Bureau of Economic Analysis (BEA) and expressed in 1990 U.S. dollars using the Bureau of Labor Statistics' CPI Research Series deflator. BEA collects income data according to place of work and adjusts it for place of 
residence. This adjustment makes per capita income data in line with Census data, since all Census data are collected according to place of residence. As described earlier, the dependent variable is the income level rather than the growth rate, measured by the log of average per capita income for the period 1980-1999. Variable definitions and sources are depicted in Table 3.2, while descriptive statistics are displayed in Table 3.3.

The study utilizes a large dataset controlling for as many possible growth determinants as possible. All variables are measured as initial period values (i.e. 1980 values) to avoid endogeneity problems. Initial period level of income, one common variable included in growth regressions, is included to control for conditional convergence.

The study utilizes 11 employment-by-industry variables to control for industry $\operatorname{mix}^{13}$. Following Lopez-Bazo et al. (2004) and LeSage and Fischer (2008), the logged levels of employment are used. Following Higgins et al. (2006), the size of the public sector is included. The logged levels of employment in federal, state and local governments are discerned to identify their separate effects. Finally, logged levels of self employed are included.

\footnotetext{
${ }^{13}$ The industry groups are agriculture, forestry, fisheries and mining; construction; manufacturing of durables and nondurables; transportation, communication and other public utilities; wholesale and retail; finance, insurance and real estate; business and repair services; personal, entertainment and recreation services; health services; educational services, other professional and related services.
} 
Table 3.2: Variable Definitions and Sources

\begin{tabular}{|c|c|c|}
\hline Variable list & Definition & Source \\
\hline Dependent variable & $\begin{array}{l}\text { Log of average per capita personal income for the } \\
\text { period } 1980-1999 \text { (constant } 1990 \$ \text { ) }\end{array}$ & BEA \\
\hline Initial income & $\begin{array}{l}\text { Log of real per capita personal income in } 1980 \\
\text { (1990 US Dollar prices) }\end{array}$ & \\
\hline \multicolumn{3}{|c|}{ Employment by Industry } \\
\hline $\begin{array}{l}\text { Agriculture, forestry, } \\
\text { fisheries, mining }\end{array}$ & Log of initial period population employed & Census \\
\hline Construction & Log of initial period population employed & Census \\
\hline Manufacturing & Log of initial period population employed & Census \\
\hline $\begin{array}{l}\text { Transportation, } \\
\text { communication and } \\
\text { other public utilities }\end{array}$ & Log of initial period population employed & Census \\
\hline Wholesale and retail & Log of initial period population employed & Census \\
\hline $\begin{array}{l}\text { Finance, insurance and } \\
\text { real estate }\end{array}$ & Log of initial period population employed & Census \\
\hline $\begin{array}{l}\text { Business and repair } \\
\text { services }\end{array}$ & Log of initial period population employed & Census \\
\hline $\begin{array}{l}\text { Personal, } \\
\text { entertainment and } \\
\text { recreation services }\end{array}$ & Log of initial period population employed & Census \\
\hline Health services & Log of initial period population employed & Census \\
\hline Educational services & Log of initial period population employed & Census \\
\hline $\begin{array}{l}\text { Other professional and } \\
\text { related services }\end{array}$ & Log of initial period population employed & Census \\
\hline \multicolumn{3}{|c|}{ Government Employment } \\
\hline Federal government & Log of initial period population employed & Census \\
\hline State government & Log of initial period population employed & Census \\
\hline Local government & Log of initial period population employed & Census \\
\hline Self Employment & Log of initial period population employed & Census \\
\hline Human Capital & Log of initial period population with a college degree & Census \\
\hline Poverty & Log of initial period population below the poverty line & Census \\
\hline Population density & Logged county population divided by county area & Census \\
\hline Area & Logged county area & Census \\
\hline NAIX & Natural Amenities Index & USDA \\
\hline Collegetown dummy & $\begin{array}{l}\text { Dummy }=1 \text { if the county had a college or university } \\
\text { enrollment to population ratio greater than or equal } \\
\text { to } 20 \% \text {, } \\
0 \text { otherwise }\end{array}$ & $\begin{array}{l}\text { National } \\
\text { Center for } \\
\text { Educational } \\
\text { Statistics }\end{array}$ \\
\hline
\end{tabular}

All variables are measured as initial period values (i.e. 1980 values) 
Table 3.3: Descriptive Statistics

\begin{tabular}{|l|r|r|r|r|}
\hline Variable & \multicolumn{1}{|l|}{ Mean } & \multicolumn{1}{l|}{ Std. Dev. } & \multicolumn{1}{l|}{ Min } & \multicolumn{1}{l|}{ Max } \\
\hline Dependent Variable & $15,075.30$ & $3,223.56$ & $5,910.95$ & $45,621.42$ \\
\hline Initial Income & $12,638.88$ & $2,884.86$ & $3,793.31$ & $30,290.42$ \\
\hline $\begin{array}{l}\text { Agriculture, Forestry, Fisheries and } \\
\text { Mining Employment }\end{array}$ & $1,272.82$ & $2,202.38$ & 6 & 64,060 \\
\hline Construction Emp. & $1,814.40$ & $5,531.72$ & 1 & 154,612 \\
\hline Manufacturing Emp. & $7,040.13$ & $26,224.56$ & 1 & 884,139 \\
\hline $\begin{array}{l}\text { Transportation, Communication and } \\
\text { other Public Utilities Emp. }\end{array}$ & $2,234.80$ & $8,447.25$ & 2 & 248,416 \\
\hline Wholesale and Retail Emp. & $6,328.98$ & $22,380.66$ & 2 & 700,108 \\
\hline Finance, Insurance and Real Estate Emp. & $1,866.13$ & $8,344.95$ & 1 & 249,271 \\
\hline Business and Repair Services Emp. & $1,285.49$ & $5,925.64$ & 1 & 203,265 \\
\hline $\begin{array}{l}\text { Personal, Entertainment and } \\
\text { Recreational Services Emp. }\end{array}$ & $1,274.45$ & $5,208.80$ & 1 & 195,217 \\
\hline Health Services Emp. & $2,296.69$ & $8,238.12$ & 1 & 250,413 \\
\hline Educational Services Emp. & $2,655.39$ & $8,274.17$ & 3 & 250,293 \\
\hline Other Professional and Related Services & $1,312.12$ & $5,471.20$ & 1 & 170,887 \\
\hline Emp. & $1,114.11$ & $4,047.05$ & 1 & 91,087 \\
\hline Federal Government Emp. & $1,406.19$ & $3,763.21$ & 1 & 82,658 \\
\hline State Government Emp. & $2,680.50$ & $9,387.05$ & 12 & 297,074 \\
\hline Local Government Emp. & $2,139.83$ & $6,189.09$ & 11 & 235,754 \\
\hline Self Employment & & $31,421.4$ & & \\
\hline Poverty & $8,862.83$ & 6 & 1 & $1,003,390$ \\
\hline Human Capital & $11,558.57$ & $45,110.56$ & 3.91 & $1,383,289$ \\
\hline Population Density & 182.26 & $1,562.40$ & 0.14 & $62,674.59$ \\
\hline Area & 980.75 & $1,320.91$ & 22.79 & $20,174.72$ \\
\hline NAIX & 0.05 & 2.30 & -6.4 & 11.17 \\
\hline College town Dummy & 0.02 & 0.133414 & 0 & 1 \\
\hline
\end{tabular}


It is commonly acknowledged that human capital is a key determinant of economic growth. Following LeSage and Fischer (2008), human capital is measured by the skill of the workforce as measured by the log of the number of people with a college degree. Following Fingleton (2001), logged population density as well as logged area is used. Regions with higher population density would capture agglomeration effects on economic growth. Moreover, a poverty variable, which is the logged population below poverty line is included.

As another control, a Natural Amenity Index (NAIX) created by McGranahan (1999) is employed. NAIX is calculated from standardized mean values of climate measures (January temperature, January days of sun, July temperature and July humidity), topographic variation and water area as a proportion of county area (see: http://www.ers.usda.gov/Data/NaturalAmenities). A higher NAIX score implies higher amenities.

Following Higgins et al. (2006), a college town dummy variable is created to control for higher incomes in counties which may result from holding a considerable amount of advanced degree holders. For all colleges and universities with a total enrollment of at least 10,000 students, the ratio of number of students enrolled to county's 1980 population is calculated. The county's dummy is assigned a value of 1 if its enrollment to population ratio is at least 0.2 and a value of 0 otherwise.

Finally, this study does not incorporate state dummies. Inclusion of state dummies results with many of the explanatory variables representing dummy variables, producing an invertability problem ${ }^{14}$.

\footnotetext{
${ }^{14}$ See LeSage (1999) for details on invertability problem arising from dummy variables.
} 


\subsection{Results}

\subsubsection{Results of the Bayesian Heteroskedastic Spatial Durbin Model}

The Bayesian heteroskedastic SDM regression results using two different weight matrices are reported to illustrate the ambiguity resulting from employing different weights matrix specifications. Direct, indirect, and total effects estimates for the model with the contiguity weight matrix (borders touching) specification and the fourteen nearest neighbors specification are demonstrated in Table 3.4 and Table 3.5, respectively. Measures of dispersion obtained from an MCMC estimation procedure involving 5,000 draws are included in results tables to draw inferences for significance. Estimates that imply ambiguous results across specifications are highlighted with bold font on the tables.

Direct effects estimates show the effect of a change in own-county explanatory variable characteristics on own-county income level (or growth rate). Direct effects account for feedback effects due to positive spatial dependence. For instance, the change in initial income may positively affect other counties' incomes, which, in turn, may positively affect the income of the initial typical county. As displayed on Table 3.4, a direct effect magnitude of 0.5874 for the initial income means that a 1 percent increase in own-county initial income would increase the income level of a typical region by 0.59 percent. Direct effects estimates of initial income, employment, human capital, poverty, population density, and area can be interpreted as elasticities, since their logged levels are used. 
Table 3.4: Direct, Indirect and Total Effects Estimates with Contiguity Weight Matrix

\begin{tabular}{|c|c|c|c|}
\hline Variables & Direct Effects & Indirect Effects & Total Effects \\
\hline Initial Income & $\begin{array}{l}0.5874^{* * *} \\
(0.00)\end{array}$ & $\begin{array}{c}-0.0197 \\
(0.63)\end{array}$ & $\begin{array}{l}0.5677^{* \star *} \\
(0.00)\end{array}$ \\
\hline $\begin{array}{l}\text { Agriculture, Forestry, } \\
\text { Fisheries, Mining Emp. }\end{array}$ & $\begin{array}{l}-0.0133^{* * *} \\
(0.00)\end{array}$ & $\begin{array}{l}-0.0227^{* *} \\
(0.01)\end{array}$ & $\begin{array}{l}-0.0360^{\star \star \star} \\
(0.00)\end{array}$ \\
\hline Construction Emp. & $\begin{array}{c}0.0045 \\
(0.37)\end{array}$ & $\begin{array}{c}-0.0217 \\
(0.11)\end{array}$ & $\begin{array}{c}-0.0172 \\
(0.23)\end{array}$ \\
\hline Manufacturing Emp. & $\begin{array}{c}-0.0049 \\
(0.10)\end{array}$ & $\begin{array}{c}0.0032 \\
(0.64)\end{array}$ & $\begin{array}{c}-0.0017 \\
(0.80)\end{array}$ \\
\hline $\begin{array}{l}\text { Transportation, } \\
\text { Communication and other } \\
\text { Public Utilities Emp. }\end{array}$ & $\begin{array}{c}0.0040 \\
(0.33)\end{array}$ & $\begin{array}{l}-0.0363^{* *} \\
(0.01)\end{array}$ & $\begin{array}{l}-0.0322^{* *} \\
(0.03)\end{array}$ \\
\hline $\begin{array}{l}\text { Wholesale and Retail Trade } \\
\text { Emp. }\end{array}$ & $\begin{array}{c}0.0019 \\
(0.82)\end{array}$ & $\begin{array}{l}0.0591^{*} \\
(0.05)\end{array}$ & $\begin{array}{l}0.0609^{*} \\
(0.08)\end{array}$ \\
\hline $\begin{array}{l}\text { Finance, Insurance and Real } \\
\text { Estate Emp. }\end{array}$ & $\begin{array}{l}0.0248^{* \star *} \\
(0.00)\end{array}$ & $\begin{array}{c}0.0165 \\
(0.34)\end{array}$ & $\begin{array}{l}0.0413^{* *} \\
(0.03)\end{array}$ \\
\hline $\begin{array}{l}\text { Business and Repair } \\
\text { Services Emp. }\end{array}$ & $\begin{array}{l}0.0145^{* \star *} \\
(0.00)\end{array}$ & $\begin{array}{l}0.0057 \\
(0.69)\end{array}$ & $\begin{array}{c}0.0201 \\
(0.20)\end{array}$ \\
\hline $\begin{array}{l}\text { Personal, Entertainment and } \\
\text { Recreation Services Emp. }\end{array}$ & $\begin{array}{l}0.0095^{\star *} \\
(0.03)\end{array}$ & $\begin{array}{l}0.0181 \\
(0.22)\end{array}$ & $\begin{array}{l}0.0276^{*} \\
(0.09)\end{array}$ \\
\hline Health Services Emp. & $\begin{array}{l}0.0098^{* *} \\
(0.01)\end{array}$ & $\begin{array}{c}0.0164 \\
(0.17)\end{array}$ & $\begin{array}{l}0.0262^{*} \\
(0.05)\end{array}$ \\
\hline Educational Services Emp. & $\begin{array}{l}-0.0339^{* * *} \\
(0.00)\end{array}$ & $\begin{array}{c}0.0431 \\
(0.10)\end{array}$ & $\begin{array}{l}0.0091^{*} \\
(0.09)\end{array}$ \\
\hline $\begin{array}{l}\text { Other Professional and } \\
\text { Related Services Emp. }\end{array}$ & $\begin{array}{c}0.0052 \\
(0.20)\end{array}$ & $\begin{array}{c}-0.0030 \\
(0.84)\end{array}$ & $\begin{array}{c}0.0022 \\
(0.90)\end{array}$ \\
\hline $\begin{array}{l}\text { Federal Government } \\
\text { Employment }\end{array}$ & $\begin{array}{l}0.0025 \\
(0.33)\end{array}$ & $\begin{array}{l}0.0211^{* * *} \\
(0.00)\end{array}$ & $\begin{array}{l}0.0236^{* * *} \\
(0.00)\end{array}$ \\
\hline $\begin{array}{l}\text { State Government } \\
\text { Employment }\end{array}$ & $\begin{array}{l}-0.0131^{\text {** }} \\
(0.00)\end{array}$ & $\begin{array}{c}0.0058 \\
(0.51)\end{array}$ & $\begin{array}{c}-0.0073 \\
(0.43)\end{array}$ \\
\hline $\begin{array}{l}\text { Local Government } \\
\text { Employment }\end{array}$ & $\begin{array}{l}-0.0141^{* *} \\
(0.04)\end{array}$ & $\begin{array}{c}0.0004 \\
(0.98)\end{array}$ & $\begin{array}{r}-0.0137 \\
(0.53)\end{array}$ \\
\hline Self Employment & $\begin{array}{l}0.0803^{* * *} \\
(0.00)\end{array}$ & $\begin{array}{c}-0.0063 \\
(0.64)\end{array}$ & $\begin{array}{l}0.0740^{* * *} \\
(0.00)\end{array}$ \\
\hline Poverty & $\begin{array}{l}-0.0256^{* * *} \\
(0.00)\end{array}$ & $\begin{array}{c}0.0144 \\
(0.20)\end{array}$ & $\begin{array}{c}-0.0112 \\
(0.15)\end{array}$ \\
\hline Human Capital & $\begin{array}{l}0.1133^{* * *} \\
(0.00)\end{array}$ & $\begin{array}{l}-0.0397^{*} \\
(0.08)\end{array}$ & $\begin{array}{l}0.0736^{* * *} \\
(0.00)\end{array}$ \\
\hline College town Dummy & $\begin{array}{l}-0.0194^{* \star *} \\
(0.00)\end{array}$ & $\begin{array}{l}-0.0652^{* \star *} \\
(0.00)\end{array}$ & $\begin{array}{l}-0.0846^{* * *} \\
(0.00)\end{array}$ \\
\hline Population Density & $\begin{array}{l}-0.1850^{\star * *} \\
(0.00)\end{array}$ & $\begin{array}{c}-0.0481 \\
(0.18)\end{array}$ & $\begin{array}{l}-0.2331^{* * *} \\
(0.00)\end{array}$ \\
\hline Area & $\begin{array}{l}-0.1967^{* * *} \\
(0.00)\end{array}$ & $\begin{array}{l}-0.0823^{* *} \\
(0.03)\end{array}$ & $\begin{array}{l}-0.2788^{* * *} \\
(0.00)\end{array}$ \\
\hline NAIX & $\begin{array}{c}0.0002 \\
(0.60)\end{array}$ & $\begin{array}{l}-0.0021^{\text {** }} \\
(0.03)\end{array}$ & $\begin{array}{c}-0.0018^{* *} \\
(0.03)\end{array}$ \\
\hline R-squared & \multicolumn{3}{|l|}{0.8255} \\
\hline م & \multicolumn{3}{|l|}{$\begin{array}{l}0.5315^{\star * *} \\
(0.00)\end{array}$} \\
\hline
\end{tabular}

Ambiguous estimates across different specifications are highlighted with bold fonts.

p-levels are reported in parenthesis.

$* * *$ Significant at the $99 \%$ level

$* *$ Significant at the $95 \%$ level

*Significant at the $90 \%$ level 
Table 3.5: Direct, Indirect and Total Effects Estimates with 14 Nearest Neighbors

\begin{tabular}{|c|c|c|c|}
\hline Variables & Direct Effects & Indirect Effects & Total Effects \\
\hline Initial Income & $\begin{array}{l}0.5920^{* * *} \\
(0.00)\end{array}$ & $\begin{array}{c}-0.0105 \\
(0.88)\end{array}$ & $\begin{array}{l}0.5815^{* * *} \\
(0.00)\end{array}$ \\
\hline $\begin{array}{l}\text { Agriculture, Forestry, } \\
\text { Fisheries, Mining Emp. }\end{array}$ & $\begin{array}{l}-0.0131^{* * *} \\
(0.00)\end{array}$ & $\begin{array}{c}-0.0219 \\
(0.10)\end{array}$ & $\begin{array}{l}-0.0350^{* * *} \\
(0.00)\end{array}$ \\
\hline Construction Emp. & $\begin{array}{l}0.0057 \\
(0.24) \\
\end{array}$ & $\begin{array}{c}-0.0084 \\
(0.70) \\
\end{array}$ & $\begin{array}{c}-0.0028 \\
(0.90) \\
\end{array}$ \\
\hline Manufacturing Emp. & $\begin{array}{c}-0.0043 \\
(0.13)\end{array}$ & $\begin{array}{c}0.0093 \\
(0.39)\end{array}$ & $\begin{array}{c}0.0049 \\
(0.65)\end{array}$ \\
\hline $\begin{array}{l}\text { Transportation, } \\
\text { Communication and other } \\
\text { Public Utilities Emp. }\end{array}$ & $\begin{array}{c}0.0058 \\
(0.16) \\
\end{array}$ & $\begin{array}{c}0.0429^{*} \\
(0.08)\end{array}$ & $\begin{array}{c}-0.0371 \\
(0.15) \\
\end{array}$ \\
\hline $\begin{array}{l}\text { Wholesale and Retail Trade } \\
\text { Emp. }\end{array}$ & $\begin{array}{l}0.0053 \\
(0.52)\end{array}$ & $\begin{array}{l}0.0798 \\
(0.19)\end{array}$ & $\begin{array}{c}0.0746 \\
(0.24)\end{array}$ \\
\hline $\begin{array}{l}\text { Finance, Insurance and Real } \\
\text { Estate Emp. }\end{array}$ & $\begin{array}{l}0.0256^{* \star \star} \\
(0.00)\end{array}$ & $\begin{array}{l}0.0593^{*} \\
(0.09)\end{array}$ & $\begin{array}{l}0.0850^{* *} \\
(0.02)\end{array}$ \\
\hline $\begin{array}{l}\text { Business and Repair } \\
\text { Services Emp. }\end{array}$ & $\begin{array}{l}0.0199^{* * *} \\
(0.00)\end{array}$ & $\begin{array}{c}-0.0364 \\
(0.19) \\
\end{array}$ & $\begin{array}{c}-0.0165 \\
(0.57) \\
\end{array}$ \\
\hline $\begin{array}{l}\text { Personal, Entertainment and } \\
\text { Recreation Services Emp. }\end{array}$ & $\begin{array}{l}0.0052 \\
(0.21)\end{array}$ & $\begin{array}{c}0.0204 \\
(0.45)\end{array}$ & $\begin{array}{l}0.0256 \\
(0.36)\end{array}$ \\
\hline Health Services Emp. & $\begin{array}{l}0.0090^{* *} \\
(0.01)\end{array}$ & $\begin{array}{c}0.0213 \\
(0.35) \\
\end{array}$ & $\begin{array}{c}0.0303 \\
(0.20)\end{array}$ \\
\hline Educational Services Emp. & $\begin{array}{l}-0.0347^{* * *} \\
(0.00)\end{array}$ & $\begin{array}{l}0.1015^{* *} \\
(0.04)\end{array}$ & $\begin{array}{l}0.0668^{*} \\
(0.06)\end{array}$ \\
\hline $\begin{array}{l}\text { Other Professional and } \\
\text { Related Services Emp. }\end{array}$ & $\begin{array}{l}0.0032 \\
(0.44) \\
\end{array}$ & $\begin{array}{c}-0.0071 \\
(0.81) \\
\end{array}$ & $\begin{array}{c}-0.0039 \\
(0.90) \\
\end{array}$ \\
\hline $\begin{array}{l}\text { Federal Government } \\
\text { Employment }\end{array}$ & $\begin{array}{l}0.0020 \\
(0.42) \\
\end{array}$ & $\begin{array}{l}0.0397^{* * *} \\
(0.00)\end{array}$ & $\begin{array}{l}0.0416^{* * *} \\
(0.00)\end{array}$ \\
\hline $\begin{array}{l}\text { State Government } \\
\text { Employment }\end{array}$ & $\begin{array}{l}-0.0143^{* * *} \\
(0.00)\end{array}$ & $\begin{array}{l}0.0025 \\
(0.87)\end{array}$ & $\begin{array}{c}-0.0118 \\
(0.46)\end{array}$ \\
\hline $\begin{array}{l}\text { Local Government } \\
\text { Employment }\end{array}$ & $\begin{array}{c}-0.0134^{*} \\
(0.05)\end{array}$ & $\begin{array}{c}-0.0329 \\
(0.36)\end{array}$ & $\begin{array}{c}-0.0462 \\
(0.21)\end{array}$ \\
\hline Self Employment & $\begin{array}{l}0.0798^{* * *} \\
(0.00)\end{array}$ & $\begin{array}{c}-0.0077 \\
(0.73)\end{array}$ & $\begin{array}{l}0.0722^{* * *} \\
(0.00)\end{array}$ \\
\hline Poverty & $\begin{array}{l}-0.0280^{* * *} \\
(0.00)\end{array}$ & $\begin{array}{c}0.0165 \\
(0.21)\end{array}$ & $\begin{array}{c}-0.0115 \\
(0.31)\end{array}$ \\
\hline Human Capital & $\begin{array}{l}0.1142^{\star \star \star} \\
(0.00)\end{array}$ & $\begin{array}{l}-0.0707^{*} \\
(0.07)\end{array}$ & $\begin{array}{c}0.0434 \\
(0.28)\end{array}$ \\
\hline College town Dummy & $\begin{array}{l}-0.0181^{* * *} \\
(0.00)\end{array}$ & $\begin{array}{l}-0.1443^{\star * *} \\
(0.00)\end{array}$ & $\begin{array}{l}-0.1623^{* * *} \\
(0.00)\end{array}$ \\
\hline Population Density & $\begin{array}{l}-0.1771^{* * *} \\
(0.00)\end{array}$ & $\begin{array}{c}-0.0920 \\
(0.14) \\
\end{array}$ & $\begin{array}{l}-0.2691^{* * *} \\
(0.00)\end{array}$ \\
\hline Area & $\begin{array}{l}-0.1904^{* * *} \\
(0.00)\end{array}$ & $\begin{array}{c}-0.1194^{*} \\
(0.07)\end{array}$ & $\begin{array}{l}-0.3099^{* * *} \\
(0.00)\end{array}$ \\
\hline NAIX & $\begin{array}{l}0.0006 \\
(0.20)\end{array}$ & $\begin{array}{c}-0.0028^{*} \\
(0.05)\end{array}$ & $\begin{array}{c}-0.0022 \\
(0.11)\end{array}$ \\
\hline R-squared & \multicolumn{3}{|l|}{0.8185} \\
\hline$\rho$ & \multicolumn{3}{|l|}{$\begin{array}{l}0.6517^{* \star \star} \\
(0.00)\end{array}$} \\
\hline
\end{tabular}

Ambiguous estimates across different specifications are highlighted with bold fonts.

p-levels are reported in parenthesis.

$* * *$ Significant at the $99 \%$ level

$* *$ Significant at the $95 \%$ level

*Significant at the $90 \%$ level 
In both model specifications, own-county employment in the agricultural industries and educational services are negatively related to own-county growth. Owncounty employment in finance, insurance and real estate, business and repair services, and health services have a positive impact on own-county growth. One ambiguity arising from different weight matrix specifications pertains to estimates of employment in wholesale and retail trade and entertainment and recreational services. Both estimates from the model with contiguity weight matrix specification are significant at 90 percent level, whereas estimates from the other model specification are not significant.

Across two model specifications, state and local government employment in owncounty has a significant negative impact on own-county growth, suggesting an overexpansion of the state government. Interestingly, federal government in own-county does not hinder own-county growth. Self employment and human capital have the expected positive impacts on own-county growth, with relatively large magnitudes. Poverty is associated with lower income levels. Population density, which captures the agglomeration effects, has a strong negative impact on own-county growth. This result reflects the congestion effects and disamenities connected to large cities and denser areas. Another result of interest is that college towns are associated with lower income levels, capturing the impact of disproportionate number of students residing in college towns.

Indirect effects estimates, presented in the above tables, represent spatial spillovers and capture related-county effects associated with changes in own-county level characteristics. LeSage and Pace (2009) explain that indirect effects estimates can be interpreted in two different ways. The first interpretation is named as the average total impact on an observation. This interpretation captures how a change in the initial level of 
explanatory variable characteristics of all counties by some constant amount would change the income level of a typical county.

The second interpretation is named as the average total impact from an observation, which captures the cumulative impact of a change in own-county initial level of explanatory variable characteristics averaged over all other regions. The counties that are closely related to own-county would experience greater income effects, while the ones that are loosely related would have smaller impacts.

The indirect effects estimates are rather surprising. As displayed in Table 3.4 and Table 3.5, own-county initial income, which is expected to have a significant impact on related-county incomes, is not significant in either model specification. Employment in transportation and communications, educational services, employment in federal government, human capital, natural amenities index, area, and college town impose spillover effects. Another ambiguity resulting from different weight matrix specifications concerns the estimates of employment in agricultural services, wholesale and retail trade, and finance, insurance, and real estate. The model with contiguity weight matrix specification produces estimates of agricultural services, and wholesale and retail trade, that are significant at 99 percent and 90 percent level, respectively, whereas estimates from the other model specification are not significant. On the other hand, finance, insurance, and real estate estimate from the first model specification is not significant, whereas it is significant at 90 percent level in the second specification.

Total effects estimates are the sum of direct and indirect estimates. As depicted in Table 3.4 and Table 3.5, the positive magnitude of total impact of initial income level suggests that higher income levels lead to higher current levels of county income. 
In both model specifications, employment in finance, insurance and real estate, educational services, and federal government, along with self employment has a positive impact on current income levels. Agricultural services employment, college town, population density, and area have negative impacts. Ambiguity of total effects estimates can be seen on the estimates of employment in transportation and communication, wholesale and retail trade, entertainment and recreational services, health services, human capital, and natural amenities index. Results of the model specification with the fourteen nearest neighbors weight matrix suggest that none of these variables are significant. However, using the first model specification, estimates of employment in transportation and communication, health services, and natural amenities index are significant at 95 percent level, estimates of employment in wholesale and retail trade, and entertainment and recreational services are significant at 90 percent level, and human capital is significant at 99 percent level. Employing Bayesian model averaging, discussed in the next section, will produce model averaged estimates and inferences to clarify the ambiguity pertaining to the significance of these variables.

\subsubsection{Results of the Bayesian Model Averaging}

Monte Carlo Markov Chain model composition with Bayesian model averaging is run on the sample. Table 3.6 shows the variables appearing in the five highest posterior probability models, with variables that appear in each model designated with a " 1 " and those that do not appear with a "0". The last column shows the probability that each variable should enter the model based on frequency of appearance of each variable in the top 1,000 models. 
Initial income and its spatial lag appear in all five models, and over $96 \%$ of the top 1,000 models, indicated by the inclusion probabilities of 96.4 and 96.3 , respectively. The other variable that appears in all five top models is human capital with its spatial lag. The probability of inclusion for both human capital and its spatial lag is 96.7 percent. The importance of the initial level of income and human capital is consistent with non-spatial studies of economic growth, where these variables also appeared as the most important variables (Fernandez et. al., 2001b; LeSage and Fischer, 2008).

Other variables that appear in all five top models with their spatial lags are self employment, educational services, and college town dummy. Employment in agricultural services, manufacturing, finance, insurance and real estate, state government, along with population density and area appear in all top five models, but the spatial lags of these variables do not appear in all five top models. One result of interest is the wholesale and retail trade employment. Although employment in wholesale and retail trade is not in the top models, having an inclusion probability of 5.9 percent, its spatial lag is in all five top models with 57 percent inclusion probability. 
Table 3.6: High-probability models

\begin{tabular}{|c|c|c|c|c|c|c|}
\hline Variable names & 5 & 4 & 3 & 2 & 1 & Probs. \\
\hline Initial income & 1 & 1 & 1 & 1 & 1 & 0.9648 \\
\hline $\begin{array}{l}\text { Agriculture, forestry, fisheries, mining } \\
\text { emp. }\end{array}$ & 1 & 1 & 1 & 1 & 1 & 0.8464 \\
\hline Construction emp. & 0 & 0 & 0 & 0 & 0 & 0.3012 \\
\hline Manufacturing emp. & 1 & 1 & 1 & 1 & 1 & 0.9424 \\
\hline $\begin{array}{l}\text { Transportation, communication and } \\
\text { other public utilities emp. }\end{array}$ & 0 & 0 & 0 & 0 & 0 & 0.0522 \\
\hline Wholesale and retail trade emp. & 0 & 0 & 0 & 0 & 0 & 0.0598 \\
\hline Finance, insurance and real estate emp. & 1 & 1 & 1 & 1 & 1 & 0.9688 \\
\hline Business and repair services emp. & 0 & 0 & 0 & 0 & 0 & 0.2656 \\
\hline $\begin{array}{l}\text { Personal, entertainment and recreation } \\
\text { services emp. }\end{array}$ & 0 & 0 & 0 & 0 & 0 & 0.1040 \\
\hline Health services emp. & 0 & 0 & 0 & 0 & 0 & 0.0258 \\
\hline Educational services emp. & 1 & 1 & 1 & 1 & 1 & 0.9686 \\
\hline $\begin{array}{l}\text { Other professional and related services } \\
\text { emp. }\end{array}$ & 1 & 0 & 0 & 0 & 0 & 0.4040 \\
\hline Federal government employment & 0 & 0 & 0 & 0 & 0 & 0.1290 \\
\hline State government employment & 1 & 1 & 1 & 1 & 1 & 0.9534 \\
\hline Local government employment & 0 & 0 & 0 & 0 & 0 & 0.0712 \\
\hline Self employment & 1 & 1 & 1 & 1 & 1 & 0.9628 \\
\hline Poverty & 1 & 1 & 1 & 1 & 1 & 0.9572 \\
\hline NAIX & 0 & 0 & 0 & 0 & 0 & 0.0662 \\
\hline Human capital & 1 & 1 & 1 & 1 & 1 & 0.9670 \\
\hline Population density & 1 & 1 & 1 & 1 & 1 & 0.9760 \\
\hline Area & 1 & 1 & 1 & 1 & 1 & 0.9662 \\
\hline Collegetown dummy & 1 & 1 & 1 & 1 & 1 & 0.9554 \\
\hline
\end{tabular}


Table 3.6: High-probability models (continued)

\begin{tabular}{|c|c|c|c|c|c|c|}
\hline Variable names & 5 & 4 & 3 & 2 & 1 & Probs. \\
\hline$W$ initial income & 1 & 1 & 1 & 1 & 1 & 0.9630 \\
\hline $\begin{array}{l}W \text { agriculture, forestry, fisheries, mining } \\
\text { emp. }\end{array}$ & 0 & 0 & 0 & 0 & 0 & 0.0482 \\
\hline W construction emp. & 0 & 0 & 0 & 0 & 0 & 0.0538 \\
\hline$W$ manufacturing emp. & 0 & 0 & 1 & 0 & 0 & 0.1268 \\
\hline $\begin{array}{l}W \text { transportation, communication and } \\
\text { other public utilities emp. }\end{array}$ & 0 & 0 & 0 & 0 & 0 & 0.0694 \\
\hline$W$ wholesale and retail trade emp. & 1 & 1 & 1 & 1 & 1 & 0.5722 \\
\hline $\begin{array}{l}W \text { finance, insurance and real estate } \\
\text { emp. }\end{array}$ & 0 & 0 & 0 & 0 & 0 & 0.0576 \\
\hline$W$ business and repair services emp. & 0 & 0 & 0 & 0 & 0 & 0.0468 \\
\hline $\begin{array}{l}W \text { personal, entertainment and recreation } \\
\text { services emp. }\end{array}$ & 0 & 0 & 0 & 0 & 0 & 0.3764 \\
\hline$W$ health services emp. & 0 & 0 & 0 & 0 & 0 & 0.1424 \\
\hline W educational services emp. & 1 & 1 & 1 & 1 & 1 & 0.7372 \\
\hline $\begin{array}{l}\text { W other professional and related } \\
\text { services emp. }\end{array}$ & 0 & 0 & 0 & 0 & 0 & 0.0756 \\
\hline$W$ federal government employment & 0 & 0 & 0 & 0 & 0 & 0.1520 \\
\hline$W$ state government employment & 0 & 0 & 0 & 0 & 0 & 0.0698 \\
\hline$W$ local government employment & 0 & 0 & 0 & 0 & 0 & 0.0510 \\
\hline$W$ self employment & 1 & 1 & 1 & 1 & 1 & 0.9690 \\
\hline$W$ poverty & 1 & 0 & 1 & 0 & 0 & 0.5524 \\
\hline W NAIX & 0 & 0 & 0 & 0 & 0 & 0.3106 \\
\hline$W$ human capital & 1 & 1 & 1 & 1 & 1 & 0.9672 \\
\hline$W$ population density & 1 & 0 & 0 & 1 & 0 & 0.6838 \\
\hline$W$ area & 0 & 1 & 0 & 0 & 0 & 0.6328 \\
\hline$W$ collegetown dummy & 1 & 1 & 1 & 1 & 1 & 0.3744 \\
\hline Model probabilities & 0.033 & 0.033 & 0.044 & 0.101 & 0.133 & \\
\hline
\end{tabular}


Model averaged estimates, based on the 1,000 highest probability models are reported on Table 3.7. Bayesian model averaging proves fruitful as it clarifies the ambiguity resulting from employing different spatial weight matrix specifications. As displayed on Table 3.7, human capital imposes a positive direct impact and negative spillover effects, and its total impact is positive and significant at 99 percent level. Although the natural amenities index and federal government employment exert small spillover effects, their total impact estimates are not significant.

In terms of industrial composition, agricultural services do not impose significant spillover effects. Manufacturing industries have small negative direct impact; however they do not exert significant spillover effects on other counties. Business and repair services have a small positive impact on own-county growth, but do not impose spillover effects. Wholesale and retail trade imposes small positive spillovers and its total impact is positive and significant. Employment in educational services has a negative impact on own-county income, and positive spillovers on related counties' income. Transportation and communication, entertainment and recreational services, health services, and other services are not important growth factors.

The rest of the results are similar to the previous SDM results. State government employment imposes a negative impact on own-county growth. Local government employment does not affect county growth. Self employment and poverty have positive and negative direct effects, respectively, and no significant spillover effects. College town, population density, and area exert both direct and spillover effects. 
Table 3.7: Model Averaged Estimates

\begin{tabular}{|c|c|c|c|}
\hline Variables & Direct Effects & Indirect Effects & Total Effects \\
\hline Initial Income & $\begin{array}{l}0.6199^{* * *} \\
(0.00)\end{array}$ & $\begin{array}{c}-0.0212 \\
(0.81)\end{array}$ & $\begin{array}{l}0.5987^{* * *} \\
(0.00)\end{array}$ \\
\hline $\begin{array}{l}\text { Agriculture, Forestry, } \\
\text { Fisheries, Mining Emp. }\end{array}$ & $\begin{array}{l}-0.0153^{* \star *} \\
(0.00)\end{array}$ & $\begin{array}{c}-0.0188 \\
(0.13)\end{array}$ & $\begin{array}{l}-0.0341^{* * *} \\
(0.00)\end{array}$ \\
\hline Construction Emp. & $\begin{array}{l}0.0083 \\
(0.39)\end{array}$ & $\begin{array}{c}-0.0132 \\
(0.57)\end{array}$ & $\begin{array}{c}-0.0049 \\
(0.87)\end{array}$ \\
\hline Manufacturing Emp. & $\begin{array}{l}-0.0074^{* *} \\
(0.03)\end{array}$ & $\begin{array}{c}0.0053 \\
(0.41)\end{array}$ & $\begin{array}{l}-0.0021^{* *} \\
(0.04)\end{array}$ \\
\hline $\begin{array}{l}\text { Transportation, } \\
\text { Communication and other } \\
\text { Public Utilities Emp. }\end{array}$ & $\begin{array}{c}0.0045 \\
(0.30)\end{array}$ & $\begin{array}{c}-0.0699 \\
(0.15)\end{array}$ & $\begin{array}{c}-0.0654 \\
(0.17)\end{array}$ \\
\hline $\begin{array}{l}\text { Wholesale and Retail Trade } \\
\text { Emp. }\end{array}$ & $\begin{array}{c}0.0025 \\
(0.80)\end{array}$ & $\begin{array}{l}0.0472^{* *} \\
(0.03)\end{array}$ & $\begin{array}{l}0.0497^{*} \\
(0.05)\end{array}$ \\
\hline $\begin{array}{l}\text { Finance, Insurance and Real } \\
\text { Estate Emp. }\end{array}$ & $\begin{array}{l}0.0261^{* * *} \\
(0.00)\end{array}$ & $\begin{array}{l}0.0324 \\
(0.29)\end{array}$ & $\begin{array}{l}0.0585^{* *} \\
(0.03)\end{array}$ \\
\hline $\begin{array}{l}\text { Business and Repair } \\
\text { Services Emp. }\end{array}$ & $\begin{array}{l}0.0156^{\star \star \star} \\
(0.00)\end{array}$ & $\begin{array}{l}0.0087 \\
(0.58)\end{array}$ & $\begin{array}{l}0.0243 \\
(0.68)\end{array}$ \\
\hline $\begin{array}{l}\text { Personal, Entertainment and } \\
\text { Recreation Services Emp. }\end{array}$ & $\begin{array}{l}0.0066 \\
(0.16)\end{array}$ & $\begin{array}{l}0.0231 \\
(0.50)\end{array}$ & $\begin{array}{l}0.0297 \\
(0.40)\end{array}$ \\
\hline Health Services Emp. & $\begin{array}{l}0.0104 \\
(0.14)\end{array}$ & $\begin{array}{l}0.0267 \\
(0.42)\end{array}$ & $\begin{array}{l}0.0371 \\
(0.25)\end{array}$ \\
\hline Educational Services Emp. & $\begin{array}{l}-0.0419^{* \star *} \\
(0.00)\end{array}$ & $\begin{array}{l}0.1172^{* *} \\
(0.02)\end{array}$ & $\begin{array}{l}0.0753^{* *} \\
(0.04)\end{array}$ \\
\hline $\begin{array}{l}\text { Other Professional and } \\
\text { Related Services Emp. }\end{array}$ & $\begin{array}{l}0.0045 \\
(0.38)\end{array}$ & $\begin{array}{c}-0.0028 \\
(0.83)\end{array}$ & $\begin{array}{l}0.0017 \\
(0.88)\end{array}$ \\
\hline $\begin{array}{l}\text { Federal Government } \\
\text { Employment }\end{array}$ & $\begin{array}{c}0.0031 \\
(0.42)\end{array}$ & $\begin{array}{l}0.0489^{* * *} \\
(0.00)\end{array}$ & $\begin{array}{c}0.0520 \\
(0.10)\end{array}$ \\
\hline $\begin{array}{l}\text { State Government } \\
\text { Employment }\end{array}$ & $\begin{array}{l}-0.0194^{* * *} \\
(0.00)\end{array}$ & $\begin{array}{l}0.0065 \\
(0.49)\end{array}$ & $\begin{array}{c}-0.0129 \\
(0.45)\end{array}$ \\
\hline $\begin{array}{l}\text { Local Government } \\
\text { Employment }\end{array}$ & $\begin{array}{c}-0.0150 \\
(0.11)\end{array}$ & $\begin{array}{c}-0.0359 \\
(0.39)\end{array}$ & $\begin{array}{c}-0.0509 \\
(0.20)\end{array}$ \\
\hline Self Employment & $\begin{array}{l}0.0962^{\star \star \star} \\
(0.00)\end{array}$ & $\begin{array}{c}-0.0051 \\
(0.52)\end{array}$ & $\begin{array}{l}0.0911^{* \star *} \\
(0.00)\end{array}$ \\
\hline Poverty & $\begin{array}{l}-0.0324^{\star \star \star} \\
(0.00)\end{array}$ & $\begin{array}{l}0.0179 \\
(0.21)\end{array}$ & $\begin{array}{c}-0.0145 \\
(0.26)\end{array}$ \\
\hline Human Capital & $\begin{array}{l}0.1197^{* * *} \\
(0.00)\end{array}$ & $\begin{array}{l}-0.0764^{* *} \\
(0.01)\end{array}$ & $\begin{array}{l}0.0433^{* * *} \\
(0.00)\end{array}$ \\
\hline College town Dummy & $\begin{array}{l}-0.0172^{\star \star \star} \\
(0.00)\end{array}$ & $\begin{array}{l}-0.0776^{* * *} \\
(0.00)\end{array}$ & $\begin{array}{l}-0.0948^{* * *} \\
(0.00)\end{array}$ \\
\hline Population Density & $\begin{array}{l}-0.1902^{* * *} \\
(0.00)\end{array}$ & $\begin{array}{l}-0.1069^{*} \\
(0.07)\end{array}$ & $\begin{array}{l}-0.2971^{* * *} \\
(0.00)\end{array}$ \\
\hline Area & $\begin{array}{l}-0.1994^{* * *} \\
(0.00)\end{array}$ & $\begin{array}{l}-0.0941^{* *} \\
(0.03)\end{array}$ & $\begin{array}{l}-0.2935^{* * *} \\
(0.00)\end{array}$ \\
\hline NAIX & $\begin{array}{c}0.0002 \\
(0.61)\end{array}$ & $\begin{array}{l}-0.0033^{*} \\
(0.08)\end{array}$ & $\begin{array}{c}-0.0031 \\
(0.13)\end{array}$ \\
\hline
\end{tabular}

p-levels are reported in parenthesis.

***Significant at the $99 \%$ level

**Significant at the $95 \%$ level

*Significant at the $90 \%$ level 


\subsection{Conclusion}

Spatial growth regression models produce estimates and inferences that are conditional on both the particular weight matrix used to specify the spatial dependence and the explanatory variables included in the growth regression. Employing different spatial weight matrices often lead to ambiguous results in spatial econometrics. This study applies Monte Carlo Markov Chain model composition $\mathrm{MC}^{3}$ with Bayesian model averaging on a sample of U.S. counties to deal with model uncertainty in spatial regressions and produce model averaged estimates and inferences. The study first displays the results based on two spatial weight matrices, contiguity and optimal nearest neighbors, and discusses the ambiguity resulting from different weight matrix specifications. Later, model averaged estimates are reported to resolve the uncertainty pertaining to the determinants of U.S. county growth.

The Bayesian solution to model uncertainty clarifies the ambiguous estimates across different specifications. For instance, the model averaged estimates reveal that human capital imposes a positive direct impact and negative spillover effects on related counties, and it has a positively significant total impact. The methodology also proves fruitful as it clarifies the ambiguity pertaining to the significance of employment in agricultural services, wholesale and retail trade, transportation and communication services, finance and real estate, entertainment and recreational services, health services, and natural amenities index. 


\title{
Chapter 4
}

\section{Resource Curse in U.S. Coal Counties: A Spatial}

\author{
County Growth Analysis
}




\subsection{Introduction}

The puzzling paradox of resource scarce countries outperforming resource rich countries has created an appealing debate of a "resource curse" for researchers, policy makers and developmental organizations. The resource curse hypothesis states that countries with large natural resource bases tend to grow more slowly than resource poor countries. Following the influential work of Sachs and Warner (1995), a new literature emerged examining the existence and possible transmission mechanisms of a resource curse.

One popular explanation of a resource curse is the Dutch disease. In the presence of a Dutch disease, the resource sector crowds out the manufacturing sector when a sudden resource boom increases real exchange rates and decreases the competitiveness of the latter (Auty 2001; Sachs and Warner 2001; Torvik 2001). Another possible crowding out mechanism can result if resource abundance leads to a diversion of public funds away from public good provision and education spending. Glyfason (2001) showed that resource abundance leads to lower education spending and less schooling in resource abundant countries. Rent seeking and corruption are among other indirect channels through which abundant natural resources can hinder economic growth. Fights over natural resource rents may lead to inefficient use of resources and slow down economic growth. Differences in institutional quality may be an important factor, since countries with low levels of institutional quality may be more vulnerable to the natural resource curse (Leite and Weidmann, 1999; Bulte et al., 2001, Torvik 2002).

Although a vast body of research seems to support the resource curse hypothesis and provides various explanations, several studies contest the measurement of resource abundance employed in resource curse regressions. Most empirical studies of the 
resource curse have used a resource dependence indicator proposed by Sachs and Warner (1995), which is commonly the share of primary exports in GDP. Research employing different resource dependence measures seems to lead to ambiguous growth effects. Ledermann and Maloney (2003) use the share of primary exports in total exports and primary exports over total labor force and find positive growth effects. Atkinson and Hamilton (2003) use the share of resource rents in GDP and find ambiguous effects.

The distinction between point and diffuse resources also seems to be prominent in resource curse regression results. Sala-i-Martin and Subramanian (2003) disaggregate resource exports into agricultural, and fuel and nonfuel mineral products. Their results show ambiguous growth effects. Isham, et al. (2005) discern between diffuse (agricultural products) and point resources (fuels and minerals) and find evidence of rent seeking associated with point resources only. Similarly, Bulte et al. (2005) find immobile point resources are pertinent to rent seeking activities and corruption.

Several researchers object to the use of resource dependence measures and argue that switching from relative measures of resource abundance to absolute measures of resource abundance makes the resource curse disappear across countries. Stijns (2005) replicates Sachs and Warner's (1995) cross-country data using coal, oil and gas reserves and production data as measures of resource abundance. He concludes that resource abundance has not been a significant structural determinant of economic growth. Brunnschweiler (2007) evaluates the validity of resource dependence measures and proposes to employ World Bank indicators of per capita mineral wealth and per capita total natural resource wealth, measured in USD per capita. Their cross-country regressions reveal a significant positive direct relationship between natural resource 
abundance and economic growth. Later, Brunnschweiler and Bulte (2008) show that the ratio of resource exports to GDP suffers from endogeneity problems, since dividing by the size of the economy implies that the resource dependence indicator is not independent of economic policies. They combine US dollar per capita total natural capital and subsoil assets and several measures of resource dependence and find that resource abundance, constitutions and institutions determine resource dependence. They conclude that resource abundance positively affects growth and institutional quality, whereas resource dependence does not affect growth.

This study contributes to this strand of the literature by employing U.S. countylevel data to empirically examine whether coal abundance is a curse or a blessing for county economic growth. The choice of U.S. counties as a study area is associated with several advantages. Cross country regressions suffer from poor data quality, while U.S. data are collected by a single agency, employing uniform variable definitions. U.S. counties are more homogenous than countries, sharing a common history. County data do not suffer from exchange rate variation and price variation across counties is negligible. These factors make county level resource curse analysis desirable.

There exist only a few U.S. based resource curse studies. All studies use a resource dependence indicator, which is the ratio of primary exports in GSP. Papyrakis and Gerlagh (2007) test for the presence and possible transmission channels of a resource curse across U.S. states and find evidence that natural resource abundance decreases investment, schooling, openness, research and development expenditures and increases corruption. Using data on U.S. states, Goldberg, Wibbels and Mvukiyehe (2008) provide evidence that natural resource dependence contributes to slower economic growth and 
less competitive politics. Dunn (2008) uses state level U.S. data and finds that resource abundance can lead to higher levels of rent seeking and crowd out economic activity. Contrary to previous studies, Dunn (2008) finds that both diffuse and point resources are significantly related to rent seeking. Corey (2009) examines the interaction between resource abundance and institutional quality and concludes that resource abundance only affects growth in states with low economic freedom.

Following Brunnschweiler and Bulte (2008), this study uses both an absolute measure of coal abundance and a relative measure of coal dependence to show their impacts on county growth. The absolute measure of coal abundance is the average value of coal production over the years 1981-1983 in USD per capita. The relative measure of coal dependence is the average value of coal production over the years 1981-1983 in USD divided by county income. Coal abundance in a county may potentially slow down county income growth through several transmission mechanisms. Many studies find evidence that the resource curse is largely driven by point resources rather than diffuse resources. Pertaining to the argument of rent seeking, fights over coal resource rents may crowd out productive activity and slow down economic growth. The institutional quality at the county and state level may also be an important factor in turning coal resources into a curse or a blessing.

Another contribution of this study is the employment of spatial econometrics techniques in county growth regressions. It is commonly acknowledged that regional income growth rates exhibit spatial dependence. Yet, both the literature on the resource curse and on regional growth has long overlooked the role of neighboring regions and spatial spillovers on own-region economic growth. A number of studies at the U.S. 
county level have analyzed the determinants of economic growth, but did not incorporate spatial dependence (Higgins et al., 2006; Young et al., 2008; Levernier et al., 2000, Deller and Lledo, 2007). Unlike previous research, this study accounts for spatial dependence between county income growth rates by employing appropriate spatial econometrics techniques.

Introducing spatial dependence into growth regressions changes the results dramatically. As demonstrated in this essay, when a relative measure of coal dependence is used, OLS results suggest a coal curse, while an absolute measure of coal abundance is not significant. These OLS results are consistent with the strand of cross-country growth literature that suggests that switching from relative measures of resource dependence to absolute measures of resource abundance makes the resource curse disappear across countries (Stijns, 2005; Brunnschweiler, 2007). This study employs spatial econometrics and reveals that the signs of the absolute and the relative coal abundance variables are reversed with the introduction of spatial dependence into county growth regressions. Unlike non-spatial models, the results suggest that when measured as a relative variable, coal dependence turns out to have a positive significant direct impact on own-county growth, and positive spillover impacts on related counties' growth. On the other hand, when measured as an absolute variable, coal abundance does not impact own-county growth, nor imposes spatial spillovers. This implies that switching from non-spatial growth models to spatial growth models reverses the coal curse.

The remainder of the paper is organized as follows. Section 4.2 describes the methodology and data, section 4.3 discusses the results and section 4.4 concludes. 


\subsection{Methodology and Data}

\subsubsection{Methodology}

\subsubsection{Spatial Growth Regression Models}

The literature on spatial growth estimations has been vague about the model specification to be used in spatial growth regressions (Abreu et al. 2004). LeSage and Fischer (2008) clarify the issue of spatial growth model specification by demonstrating that in the presence of an omitted variable, that is correlated with an included variable, spatial dependence in the disturbances of an OLS regression leads to a Spatial Durbin Model $(\mathrm{SDM})^{15}$. They suggest that a key finding in the growth literature is the spatial dependence between per capita income levels, employment and population variables among regions. They also argue that difficult to quantify or unobservable characteristics may exhibit spatial dependence and be correlated with one or more included variables. For instance, a hard to quantify variable, physical capital, is often ignored in regressions, whereas human capital is often included by using some measure of educational attainment. Physical and human capital are likely to be correlated and exhibit spatial dependence.

A general Spatial Durbin Model for a growth regression can be formulated as follows:

$$
y=\rho W y+\alpha \imath+X \beta+W X \theta+\varepsilon
$$

where $y$ is income growth rates, $\mathrm{X}$ is a set of explanatory variables influencing growth rates, and $l$ is the intercept vector. $W$ is an $n x n$ non-negative spatial weight matrix, defining the spatial connectivity among observations. The elements of $W$ take a positive

\footnotetext{
${ }^{15}$ See LeSage and Fischer (2008) for details regarding SDM derivation in growth models.
} 
value if an observation in region $i$ is related to an observation in region $j$, and zero otherwise. The $W$ matrix is normalized to have row sums of one. This expresses the spatial lag $W y$ as a linear combination of growth rates of related regions. $\rho$ is a scalar parameter, indicating a measure of average influence of related regions' growth rates on own-region growth rates. $\rho$ is expected to have a positive value of less than one, in spatial growth regressions, suggesting that own-region growth rates are positively related to a linear combination of related regions' growth rates. $W X$ shows a linear combination of explanatory variables from related regions and includes initial period values of explanatory variables to avoid endogeneity. This also enables modeling initial regional attributes as endowments that affect future regional growth. The error term is symbolized with $\varepsilon$ and assumed to be normally distributed with a mean of zero and constant variance.

LeSage and Fischer (2008) introduce the specific functional form that should be employed in spatial growth regressions. A non-spatial growth regression (2), which is a function of (logged) initial income and a vector of structural characteristics of the economy between time $t=0$ and $t=T$ would look as follows:

$$
\begin{aligned}
& {\left[\ln \left(y_{t}\right)-\ln \left(y_{0}\right)\right] / T=\phi \ln \left(y_{0}\right)+X_{0} \beta+\varepsilon_{t}} \\
& \ln \left(y_{t}\right)=(1+T \phi) \ln \left(y_{0}\right)+T X_{0} \beta+T \varepsilon_{t}
\end{aligned}
$$

Assuming that regional growth rates are spatially dependent due to omitted variables, the SDM generalization of the model is formulated as ${ }^{16}$ :

\footnotetext{
${ }^{16}$ See LeSage and Fischer (2008) for details on SDM generalization of growth models.
} 


$$
\begin{aligned}
& \left(I_{n}-\rho W\right)\left[\ln \left(y_{t}\right)\right]-\ln \left(y_{0}\right) / T=\phi \ln \left(y_{0}\right)+X_{0} \beta_{1}+W X_{0} \beta_{2}+\varepsilon_{t} \\
& \left(I_{n}-\rho W\right) \ln \left(y_{t}\right)=(1+T \phi) \ln \left(y_{0}\right)-\rho W \ln \left(y_{0}\right)+T X_{0} \beta_{1}+T W X_{0} \beta_{2}+T \varepsilon_{t} \\
& \ln \left(y_{t}\right)=\rho W \ln \left(y_{t}\right)+(1+T \phi) \ln \left(y_{0}\right)-\rho W \ln \left(y_{0}\right)+T X_{0} B_{1}+T W X_{0} \beta_{2}+T \varepsilon_{t}
\end{aligned}
$$

Equation (4) is the Spatial Durbin Model. After rearranging terms, the dependent variable is no longer a growth rate, but county income level instead. The explanatory variables consist of initial income levels, initial levels of explanatory variables, and spatial lags of initial income levels and explanatory variables. Unlike non-spatial growth models, the SDM accounts for the characteristics of related regions as denoted by $W X_{0}$, as well as the level of spatial dependence $\rho$ and the connectivity structure defined by the weight matrix.

The specification of the spatial weight matrix, which reflects the connectivity between regions, can be tricky in spatial growth regressions. Different spatial weight matrices may change the dispersion of estimated coefficients, leading to ambiguous results. This study will first report results obtained by employing two different weight matrix specifications (contiguity and optimal nearest neighbors specifications) on a sample of U.S. counties. This will demonstrate the ambiguous results from models with different weight matrix specifications. Later, Bayesian model averaging will be employed to deal with model uncertainty and provide model averaged estimates.

The first weight matrix specification, first-order contiguity (borders touching), is a traditional approach of defining regions as neighbors with a common border. The optimal nearest neighbors is used as the second weight matrix specification. This study follows the Bayesian model comparison defined in Lesage and Pace (2009). First the SAR 
models with different number of nearest neighbors weight matrix specifications (1 to 15 nearest neighbors) are run against each other ${ }^{17}$. The SAR model with 8 nearest neighbors wins with a probability of 0.85 . Next, the same procedure is employed on the SEM and the SDM specifications. The winning model specifications are the SEM with 7 nearest neighbors with a probability of 0.90 and the SDM with 14 nearest neighbors with a probability of 0.95 . In the final stage, the winners of the above process; the SAR model with 8 nearest neighbors, the SEM with 7 nearest neighbors, and the SDM with 14 nearest neighbors specifications are run against each other. The model specification that has the highest probability of describing the data is found as the SDM with an optimal number of 14 nearest neighbors. When run against each other, the SDM with a spatial weight matrix of 14 nearest neighbors produces a probability of 1 , whereas the other models with different neighbor specifications result in probabilities of 0 . A summary of the results for different model specifications is provided in Table 4.1.

\footnotetext{
${ }^{17}$ See LeSage and Pace (2009) for details on Bayesian model selection for different model specifications and different weight matrices.
} 


\section{Table 4.1: Summary Results for Bayesian Model Selection}

\begin{tabular}{cccc}
\hline \multirow{2}{*}{$\begin{array}{c}\text { Posterior Probabilities } \\
\text { Number of Nearest }\end{array}$} & SAR & SEM & SDM \\
$\mathbf{1}$ & & & \\
$\mathbf{2}$ & 0.10 & 0.00 & 0.00 \\
$\mathbf{3}$ & 0.00 & 0.00 & 0.00 \\
$\mathbf{4}$ & 0.00 & 0.00 & 0.00 \\
$\mathbf{5}$ & 0.00 & 0.00 & 0.00 \\
$\mathbf{6}$ & 0.00 & 0.04 & 0.00 \\
$\mathbf{7}$ & 0.00 & 0.06 & 0.00 \\
$\mathbf{8}$ & 0.05 & $\mathbf{0 . 9 0}$ & 0.00 \\
$\mathbf{9}$ & $\mathbf{0 . 8 5}$ & 0.00 & 0.00 \\
$\mathbf{1 0}$ & 0.06 & 0.00 & 0.00 \\
$\mathbf{1 1}$ & 0.04 & 0.00 & 0.00 \\
$\mathbf{1 2}$ & 0.00 & 0.00 & 0.00 \\
$\mathbf{1 3}$ & 0.00 & 0.00 & 0.02 \\
$\mathbf{1 4}$ & 0.00 & 0.00 & 0.03 \\
$\mathbf{1 5}$ & 0.00 & 0.00 & $\mathbf{0 . 9 5}$ \\
& 0.00 & 0.00 & 0.00 \\
Final Run & & & \\
\hline
\end{tabular}

Next, the Bayesian heteroskedastic SDM estimation procedure described in LeSage and Pace (2009) is employed ${ }^{18}$. Bayesian estimation allows for both non-constant variance across space and outliers. The error terms are not normal, but more likely to follow a Student-t distribution, when a particular region follows a different relationship from that of the majority of spatial observations. In this case, a set of variance scalars $\left(v_{l}\right.$, $\left.\ldots, v_{n}\right)$ can be introduced as unknown parameters to be estimated. This allows the assumption of non-constant variance across space. This enables unit estimates of $v_{i}$ to indicate constant variance, while large estimates of $v_{i}$ indicate heteroskedasticity or outliers. Large $v_{i}$ values downweight outliers or observations with large variances.

\footnotetext{
${ }^{18}$ Heteroskedasticity tests suggest non-constant variance.
} 
The Bayesian heteroskedastic Spatial Durbin Model is specified as follows:

$$
\begin{aligned}
& y=\rho W y+\alpha l+X \beta+W X \theta+\varepsilon \\
& \varepsilon \sim N\left(0, \sigma^{2} V\right) \quad V=\operatorname{diag}\left(v_{1}, \ldots, v_{n}\right) \\
& \pi(\beta) \sim N(c, T) \\
& \pi\left(r / v_{i}\right) \sim \operatorname{iid} \chi^{2}(r) \\
& \pi\left(1 / \sigma^{2}\right) \sim \Gamma(d, v) \\
& \pi(\rho) \sim U[-1,1]
\end{aligned}
$$

The prior distributions are displayed by $\pi$. $\beta$ follows normal, $\sigma$ follows gamma and $\rho$ follows a uniform prior distribution. The prior distribution for the $v_{i}$ terms is independent $\chi^{2}(r) / r$ distribution, where the parameter $r$ is the degrees of freedom in $\chi^{2}$ distribution and chosen by the researcher. The parameters $\beta, V$ and $\sigma$ in the heteroskedastic SDM can be estimated by drawing sequentially from the conditional distributions of these parameters ${ }^{19}$.

However, one important complication in spatial growth regressions can arise pertaining to the use of an appropriate spatial weight matrix. Spatial growth regression models produce estimates and inferences that are conditional on both the particular weight matrix used to specify the spatial dependence and the explanatory variables included in the growth regression. Using different spatial weight matrices may change the dispersion of estimated coefficients, complicating the identification of important growth factors. This study will use Monte Carlo Markov Chain with the Bayesian model averaging to produce model averaged estimates and inferences and deal with model uncertainty in spatial regressions.

\footnotetext{
${ }^{19}$ The following non-informative prior values are assigned in Bayesian heteroskedastic SDM estimation:
} $d=0, v=0$, and $r=4$. 
Table 4.5 and Table 4.6 report results from the model with first-order contiguity weight matrix, while Table 4.7 and Table 4.8 display results from the model with fourteen nearest neighbors. The ambiguous results of these spatial county growth regressions, and the model averaged estimates are discussed in section 4.3.

\subsubsection{Bayesian Model Averaging}

A recently developed Markov Chain Monte Carlo model composition $\left(\mathrm{MC}^{3}\right)$ with Bayesian model averaging framework can accommodate model uncertainty regarding the explanatory variables and the spatial weight matrix employed (LeSage and Fischer, 2008). The results of Bayesian model averaging report models with their posterior model probabilities and the probability that each variable should enter the model based on their frequency of appearance in the top 1,000 models (top number of models is chosen by the researchers). Bayesian solution to model uncertainty weighs the estimates from each model by their posterior model probability. It reports a linear combination of estimates from more than one model, producing model averaged estimates. Inferences based on model averaged estimates would embody model uncertainty, since these reflect estimates that arise from different models with different weight matrices and different explanatory variables. This contrasts with the conventional methods that can underestimate dispersion in estimates, since these methods condition on a single selected model and ignore model uncertainty.

Following LeSage and Fischer (2008), SDM is specified for Bayesian model comparison as:

$$
y=\alpha l+\rho W(h, d) y+X B+W(h, d) X \theta+\varepsilon
$$


where $W$ is the spatial weight matrix, $h$ is the number of nearest neighbors used to construct the weight matrix and $d$ is the type of spatial weight matrix. The types of spatial weight matrix can be based on great circle distances between regions.

Prior probabilities, $\pi\left(M_{i}\right), i=1, \ldots, m$ for each of the $\mathrm{m}$ different models, $\mathrm{M}=$ $\mathrm{M}_{1}, \mathrm{M}_{2}, \ldots, \mathrm{M}_{\mathrm{m}}$ and prior distributions for the parameters $\pi(\eta)$, where $\eta=(\rho, \alpha, \beta, \theta, \sigma$, $\mathrm{h}, \mathrm{d}$ ) are assigned. The prior distribution of $h$ (such as between 1 and 15), reflects the range of nearest number of neighbors in the weight matrix.

The prior probabilities are set equal to $1 / m$, making each model equally likely a priori. Then, these are combined with the likelihood for y conditional on $\eta$ and the models $\mathrm{M}$, which is shown as the expression $p(y \backslash \eta, M)$. The joint probability for $M, \eta$ and $y$ is:

$$
p(M, \eta, y)=\pi(M) \pi(\eta \backslash M) p(y \backslash \eta, M)
$$

The joint posterior distribution for models and parameters, given data is:

$$
p(M, \eta \backslash y)=\frac{\pi(M) \pi(\eta \backslash M) p(y \backslash \eta, M)}{p(y)}
$$

The posterior probabilities regarding the models are:

$$
p(M \backslash y)=p(M, \eta \backslash y) d \eta
$$

Expression (8) requires integrating over the parameter vector $\eta$. Lesage and Parent (2007) develop expressions for the marginal posterior in (8) for the Spatial Durbin 
Model, for the case of fixed parameters $h$ (number of neighbors used in the weight matrix) and $d$ (type of weight matrix). LeSage and Fischer (2008) extend Lesage and Parent's (2007) log-marginal likelihood for a given model to condition on $h$ and $d$. This implies an additional integration over the parameters $h$ and $d$, which take on a discrete number of values:

$$
\begin{aligned}
& p(M \backslash y)=\iint_{d} \int_{h} p^{*}(M, \rho, h \backslash j) d \rho, d h, d d \\
& p^{*}(M, \rho, h, d \backslash j)=\int_{\eta} p(M, \alpha, \beta, \theta, \sigma, \rho, h, d \backslash y) d \eta
\end{aligned}
$$

LeSage and Parent (2007) explain how to use the $\mathrm{MC}^{3}$ method by moving a Markov Chain Monte Carlo sampler through a potentially large model space to sample regions of high posteriors. This eliminates the need to consider all possible models. The constructed sampler explores relevant parts of the very large model space. Let $\mathrm{M}$ be the current model state. An extended notion of model neighborhood involves models containing the same type of weight matrix, with one more neighbor, or one less neighbor. Using the following model acceptance probability, proposed model $M^{\prime}$ is compared to current model state M.

$$
\min \left[1, \frac{p\left(M^{\prime} \backslash y\right)}{p(M \backslash y)}\right]
$$


LeSage and Parent (2007) describe the implementation of univariate numerical integration methods to construct a Metropolis-Hastings sampling schema that enables the $\mathrm{MC}^{3}$ method. A vector of the log-marginal values for the current model $\mathrm{M}$ and proposed model $M^{\prime}$ are stored during sampling. Then these are scaled and integrated to produce the ratio $p\left(M^{\prime} \backslash y\right) / p(M \backslash y)$ in (10) to determine acceptance or rejection of the proposed model.

\subsubsection{Data}

The majority of the data used in this study comes from the 1980 U.S. Census. Variable definitions and sources are depicted in Table 4.2, while descriptive statistics are displayed in Table 4.3. The dataset is comprised of 3035 county-level observations. The variables of focus in this study are the absolute measure of coal abundance and the relative measures of coal dependence. Most studies confirming resource curse use a relative measure of resource dependence, which is typically the share of primary exports in GDP in the case of cross-country analysis or GSP in the case of U.S. based studies. This study uses both an absolute and a relative indicator of coal abundance, to show their impacts on county growth. The absolute measure of coal abundance is calculated as the average value of coal production during the period 1981-1983 divided by 1980 county population. The logged transformation of the coal abundance measure is used in the regressions. The relative measure of coal abundance is created by dividing the average value of coal production during the period $1981-1983$ by 1980 county income.

County level coal production data come from Energy Information Administration (EIA). Only bituminous coal production is included in the variable. Instead of using raw 
coal production data, monetary value of coal production is calculated to distinguish between the values of different minerals ${ }^{20}$. Coal prices are obtained from EIA and expressed in 1990 dollars using the Bureau of Labor Statistics' CPI Research Series deflator. Average value of coal production over the years 1981-1983 is calculated by multiplying each year's coal production by real bituminous coal price and dividing by the number of years.

\footnotetext{
${ }^{20}$ When production values are used, a ton of oil and a ton of coal are treated equally. Calculating the value of mineral production overcomes this problem.
} 
Table 4.2: Variable Definitions and Sources

\begin{tabular}{|c|c|c|}
\hline Variable list & Definition & Source \\
\hline Dependent variable & $\begin{array}{l}\text { Log of average per capita personal income for the } \\
\text { period } 1980-1999 \text { (constant } 1990 \$ \text { ) }\end{array}$ & BEA \\
\hline Initial income & $\begin{array}{l}\text { Log of real per capita personal income in } 1980 \\
\text { (1990 US Dollar prices) }\end{array}$ & \\
\hline $\begin{array}{l}\text { Coal production per } \\
\text { capita }(\$)\end{array}$ & $\begin{array}{l}\text { Average value of coal production (1981-1983) } \\
\text { divided by } 1980 \text { county population (logged) }\end{array}$ & EIA \\
\hline $\begin{array}{l}\text { Coal production per } \\
\text { income (\$) }\end{array}$ & $\begin{array}{l}\text { Average value of coal production (1981-1983) } \\
\text { divided by } 1980 \text { county income }\end{array}$ & EIA \\
\hline \multicolumn{3}{|c|}{ Employment by Industry } \\
\hline $\begin{array}{l}\text { Agriculture, forestry, } \\
\text { fisheries, mining }\end{array}$ & Log of initial period population employed & Census \\
\hline Construction & Log of initial period population employed & Census \\
\hline Manufacturing & Log of initial period population employed & Census \\
\hline $\begin{array}{l}\text { Transportation, } \\
\text { communication and } \\
\text { other public utilities }\end{array}$ & Log of initial period population employed & Census \\
\hline Wholesale and retail & Log of initial period population employed & Census \\
\hline $\begin{array}{l}\text { Finance, insurance and } \\
\text { real estate }\end{array}$ & Log of initial period population employed & Census \\
\hline $\begin{array}{l}\text { Business and repair } \\
\text { services }\end{array}$ & Log of initial period population employed & Census \\
\hline $\begin{array}{l}\text { Personal, } \\
\text { entertainment and } \\
\text { recreation services }\end{array}$ & Log of initial period population employed & Census \\
\hline Health services & Log of initial period population employed & Census \\
\hline Educational services & Log of initial period population employed & Census \\
\hline $\begin{array}{l}\text { Other professional and } \\
\text { related services }\end{array}$ & Log of initial period population employed & Census \\
\hline \multicolumn{3}{|c|}{ Government Employment } \\
\hline Federal government & Log of initial period population employed & Census \\
\hline State government & Log of initial period population employed & Census \\
\hline Local government & Log of initial period population employed & Census \\
\hline Self Employment & Log of initial period population employed & Census \\
\hline Human Capital & Log of initial period population with a college degree & Census \\
\hline Poverty rate & Log of initial period population below the poverty line & Census \\
\hline Population density & Logged county population divided by county area & Census \\
\hline Area & Logged county area & Census \\
\hline NAIX & Natural Amenities Index & USDA \\
\hline Collegetown dummy & $\begin{array}{l}\text { Dummy }=1 \text { if the county had a college or university } \\
\text { enrollment to population ratio greater than or equal } \\
\text { to } 20 \% \\
0 \text { otherwise }\end{array}$ & $\begin{array}{l}\text { National } \\
\text { Center for } \\
\text { Educational } \\
\text { Statistics } \\
\end{array}$ \\
\hline
\end{tabular}

All variables are measured as initial period values (i.e. 1980 values) 
Table 4.3: Descriptive Statistics

\begin{tabular}{|l|r|r|r|r|}
\hline Variable & \multicolumn{1}{|l|}{ Mean } & \multicolumn{1}{l|}{ Std. Dev. } & \multicolumn{1}{l|}{ Min } & \multicolumn{1}{l|}{ Max } \\
\hline Dependent Variable & $15,075.30$ & $3,223.56$ & $5,910.95$ & $45,621.42$ \\
\hline Coal production per capita in USD & 346.17 & $3,163.68$ & 1 & $104,192.60$ \\
\hline Coal production per income in USD & 0.03 & 0.25 & 0 & 10.11 \\
\hline Initial Income & $12,638.88$ & $2,884.86$ & $3,793.31$ & $30,290.42$ \\
\hline $\begin{array}{l}\text { Agriculture, Forestry, Fisheries and } \\
\text { Mining Employment }\end{array}$ & $1,272.82$ & $2,202.38$ & 6 & 64,060 \\
\hline Construction Emp. & $1,814.40$ & $5,531.72$ & 1 & 154,612 \\
\hline Manufacturing Emp. & $7,040.13$ & $26,224.56$ & 1 & 884,139 \\
\hline $\begin{array}{l}\text { Transportation, Communication and } \\
\text { other Public Utilities Emp. }\end{array}$ & $2,234.80$ & $8,447.25$ & 2 & 248,416 \\
\hline Wholesale and Retail Emp. & $6,328.98$ & $22,380.66$ & 2 & 700,108 \\
\hline Finance, Insurance and Real Estate Emp. & $1,866.13$ & $8,344.95$ & 1 & 249,271 \\
\hline Business and Repair Services Emp. & $1,285.49$ & $5,925.64$ & 1 & 203,265 \\
\hline $\begin{array}{l}\text { Personal, Entertainment and } \\
\text { Recreational Services Emp. }\end{array}$ & $1,274.45$ & $5,208.80$ & 1 & 195,217 \\
\hline Health Services Emp. & $2,296.69$ & $8,238.12$ & 1 & 250,413 \\
\hline Educational Services Emp. & $2,655.39$ & $8,274.17$ & 3 & 250,293 \\
\hline $\begin{array}{l}\text { Other Professional and Related Services } \\
\text { Emp. }\end{array}$ & $1,312.12$ & $5,471.20$ & 1 & 170,887 \\
\hline Federal Government Emp. & $1,114.11$ & $4,047.05$ & 1 & 91,087 \\
\hline State Government Emp. & $1,406.19$ & $3,763.21$ & 1 & 82,658 \\
\hline Local Government Emp. & $2,680.50$ & $9,387.05$ & 12 & 297,074 \\
\hline Self Employment & $2,139.83$ & $6,189.09$ & 11 & 235,754 \\
\hline Poverty & $8,862.83$ & $31,421.46$ & 1 & $1,003,390$ \\
\hline Human Capital & $11,558.57$ & $45,110.56$ & 3.91 & $1,383,289$ \\
\hline Population Density & 182.26 & $1,562.40$ & 0.14 & $62,674.59$ \\
\hline Area & 980.75 & $1,320.91$ & 22.79 & $20,174.72$ \\
\hline NAIX & 0.05 & 2.29 & -6.4 & 11.17 \\
\hline College town Dummy & 0.02 & 0.13 & 0 & 1 \\
\hline
\end{tabular}


The study utilizes a large dataset controlling for as many growth determinants as possible. All variables are measured as initial period values (i.e. 1980 values) to avoid endogeneity problems. Initial period level of income, one common variable included in growth regressions, is included to control for conditional convergence. This study uses per capita personal income data obtained from the Bureau of Economic Analysis (BEA) and expressed in 1990 U.S. dollars, using the CPI Research Series deflator. BEA income data is collected according to place of work and adjusted for place of residence, to make the income data compatible with Census data. The dependent variable is the income level rather than the growth rate, measured by the log of average per capita income for the period 1980-1999.

This study controls for industry mix by incorporating 11 employment-by-industry variables $^{21}$. The logged levels of employment are used, following Lopez-Bazo et al. (2004) and LeSage and Fischer (2008). Following Higgins et al. (2006), the size of the public sector is controlled by employing the logged levels of employment in federal, state and local governments. Additionally, logged levels of self employed are included to obtain its marginal effect.

The economic growth literature has often identified human capital as an important growth determinant. This study follows LeSage and Fischer (2008) and measures human capital by the log of the number of people with a college degree. Following Fingleton (2001), logged population density as well as logged area is used. Agglomeration effects on economic growth may be captured by regions with higher population density.

\footnotetext{
${ }^{21}$ The industry groups are agriculture, forestry, fisheries and mining; construction; manufacturing of durables and nondurables; transportation, communication and other public utilities; wholesale and retail; finance, insurance and real estate; business and repair services; personal, entertainment and recreation services; health services; educational services, other professional and related services.
} 
Additionally, a poverty variable, which is the percentage of population below poverty line, is included as another control.

Natural Amenity Index (NAIX), which is calculated from standardized mean values of climate measures (January temperature, January days of sun, July temperature and July humidity), topographic variation and water area as a proportion of county area are included in the dataset (see: http://www.ers.usda.gov/Data/NaturalAmenities). A higher NAIX score implies higher amenities.

Following Higgins et al. (2006), a college town dummy variable is created to account for lower incomes in counties which may result from holding a considerable amount of students. For all colleges and universities with a total enrollment of at least 10,000 students, the ratio of number of students enrolled to county's 1980 population is calculated. The county's dummy is assigned a value of " 1 " if its enrollment to population ratio is at least 0.2 and a value of " 0 " otherwise.

Finally, this study does not include state dummies. Inclusion of state dummies results in many of the explanatory variables representing dummy variables, producing an invertability problem ${ }^{22}$.

\subsection{Results}

\subsubsection{Results of the Bayesian Heteroskedastic Spatial Durbin Model}

The Bayesian heteroskedastic SDM is run for two different weight matrix specifications. Table 4.4 reports direct, indirect and total effects estimates for the model with a contiguity weight matrix (borders touching) specification and an absolute measure of coal abundance, while Table 4.5 reports estimates for the model with a relative measure of

${ }^{22}$ See LeSage (1999) for details on invertability problem arising from dummy variables. 
coal dependence. Table 4.6 displays results of the Bayesian solution of fourteen optimal nearest neighbors with an absolute measure of coal abundance, whereas Table 4.7 shows estimates for the model with a relative measure of coal dependence. Measures of dispersion obtained from an MCMC estimation procedure involving 5,000 draws are included in results tables to draw inferences for significance. In addition, OLS estimates are reported in Table 4.8 to allow comparisons, since previous resource curse studies typically use either simple OLS or non-spatial growth models.

Direct effects estimates show the effect of a change in own-county explanatory variable characteristics on own-county income level (or growth rate). Spatial dependence results in feedback effects. For instance, a change in initial income may positively affect other counties' income, which, in turn, may positively affect the income of the initial typical county. Direct effects account for feedback effects due to spatial dependence. 
Table 4.4: Direct, Indirect and Total Effects Estimates with Contiguity Weight Matrix and an Absolute Measure of Coal Abundance

\begin{tabular}{|c|c|c|c|}
\hline Variable & Direct Effects & Indirect Effects & Total Effects \\
\hline $\begin{array}{l}\text { Coal Production per Capita } \\
\text { (\$) }\end{array}$ & $\begin{array}{l}0.0001 \\
(0.88)\end{array}$ & $\begin{array}{c}-0.0015 \\
(0.43)\end{array}$ & $\begin{array}{c}-0.0014 \\
(0.46)\end{array}$ \\
\hline Initial Income & $\begin{array}{l}0.5882^{* * *} \\
(0.00)\end{array}$ & $\begin{array}{c}-0.0165 \\
(0.69)\end{array}$ & $\begin{array}{l}0.5717^{* * *} \\
(0.00)\end{array}$ \\
\hline $\begin{array}{l}\text { Agriculture, Forestry, } \\
\text { Fisheries, Mining Emp. }\end{array}$ & $\begin{array}{l}-0.0133^{* * *} \\
(0.00)\end{array}$ & $\begin{array}{l}-0.0212^{* *} \\
(0.01)\end{array}$ & $\begin{array}{l}-0.0345^{* \star *} \\
(0.00)\end{array}$ \\
\hline Construction Emp. & $\begin{array}{c}0.0045 \\
(0.36)\end{array}$ & $\begin{array}{c}-0.0222 \\
(0.11)\end{array}$ & $\begin{array}{c}-0.0177 \\
(0.22)\end{array}$ \\
\hline Manufacturing Emp. & $\begin{array}{l}-0.0051^{*} \\
(0.09)\end{array}$ & $\begin{array}{c}0.0024 \\
(0.74)\end{array}$ & $\begin{array}{c}-0.0027 \\
(0.10)\end{array}$ \\
\hline $\begin{array}{l}\text { Transportation, } \\
\text { Communication and other } \\
\text { Public Utilities Emp. }\end{array}$ & $\begin{array}{c}0.0043 \\
(0.31)\end{array}$ & $\begin{array}{l}-0.0336^{* *} \\
(0.02)\end{array}$ & $\begin{array}{l}-0.0293^{*} \\
(0.05)\end{array}$ \\
\hline $\begin{array}{l}\text { Wholesale and Retail Trade } \\
\text { Emp. }\end{array}$ & $\begin{array}{l}0.0015 \\
(0.86)\end{array}$ & $\begin{array}{l}0.0564^{*} \\
(0.07)\end{array}$ & $\begin{array}{l}0.0579^{*} \\
(0.09)\end{array}$ \\
\hline $\begin{array}{l}\text { Finance, Insurance and Real } \\
\text { Estate Emp. }\end{array}$ & $\begin{array}{l}0.0244^{* * *} \\
(0.00)\end{array}$ & $\begin{array}{l}0.0148 \\
(0.40)\end{array}$ & $\begin{array}{l}0.0392^{* *} \\
(0.04)\end{array}$ \\
\hline $\begin{array}{l}\text { Business and Repair } \\
\text { Services Emp. }\end{array}$ & $\begin{array}{l}0.0145^{\star \star \star} \\
(0.00)\end{array}$ & $\begin{array}{c}0.0040 \\
(0.78)\end{array}$ & $\begin{array}{l}0.0185 \\
(0.23)\end{array}$ \\
\hline $\begin{array}{l}\text { Personal, Entertainment and } \\
\text { Recreation Services Emp. }\end{array}$ & $\begin{array}{l}0.0096^{* *} \\
(0.02)\end{array}$ & $\begin{array}{l}0.0183 \\
(0.20)\end{array}$ & $\begin{array}{l}0.0279^{*} \\
(0.07)\end{array}$ \\
\hline Health Services Emp. & $\begin{array}{l}0.0098^{* *} \\
(0.01)\end{array}$ & $\begin{array}{l}0.0172 \\
(0.16)\end{array}$ & $\begin{array}{l}0.0270^{* *} \\
(0.04)\end{array}$ \\
\hline Educational Services Emp. & $\begin{array}{l}-0.0339^{* * *} \\
(0.00)\end{array}$ & $\begin{array}{l}0.0425 \\
(0.11)\end{array}$ & $\begin{array}{l}0.0086 \\
(0.77)\end{array}$ \\
\hline $\begin{array}{l}\text { Other Professional and } \\
\text { Related Services Emp. }\end{array}$ & $\begin{array}{l}0.0053 \\
(0.20)\end{array}$ & $\begin{array}{c}-0.0026 \\
(0.86)\end{array}$ & $\begin{array}{l}0.0027 \\
(0.87)\end{array}$ \\
\hline $\begin{array}{l}\text { Federal Government } \\
\text { Employment }\end{array}$ & $\begin{array}{c}0.0025 \\
(0.33)\end{array}$ & $\begin{array}{l}0.0207^{* * *} \\
(0.00)\end{array}$ & $\begin{array}{l}0.0232^{* * *} \\
(0.00)\end{array}$ \\
\hline $\begin{array}{l}\text { State Government } \\
\text { Employment }\end{array}$ & $\begin{array}{l}-0.0130^{* * *} \\
(0.00)\end{array}$ & $\begin{array}{l}0.0056 \\
(0.51)\end{array}$ & $\begin{array}{c}-0.0074 \\
(0.41)\end{array}$ \\
\hline $\begin{array}{l}\text { Local Government } \\
\text { Employment }\end{array}$ & $\begin{array}{l}-0.0144^{* *} \\
(0.04)\end{array}$ & $\begin{array}{c}-0.0030 \\
(0.88)\end{array}$ & $\begin{array}{c}-0.0174 \\
(0.42)\end{array}$ \\
\hline Self Employment & $\begin{array}{l}0.0802^{* * *} \\
(0.00)\end{array}$ & $\begin{array}{c}-0.0080 \\
(0.56)\end{array}$ & $\begin{array}{l}0.0723^{* \star *} \\
(0.00)\end{array}$ \\
\hline Poverty & $\begin{array}{l}-0.0255^{* \star *} \\
(0.00)\end{array}$ & $\begin{array}{l}0.0141 \\
(0.21)\end{array}$ & $\begin{array}{c}-0.0114 \\
(0.14)\end{array}$ \\
\hline Human Capital & $\begin{array}{l}0.1132^{* * *} \\
(0.00)\end{array}$ & $\begin{array}{c}-0.0340 \\
(0.08)\end{array}$ & $\begin{array}{l}0.0732^{\star \star \star} \\
(0.00)\end{array}$ \\
\hline College town Dummy & $\begin{array}{l}-0.0193^{* * *} \\
(0.00)\end{array}$ & $\begin{array}{l}-0.0638^{* * *} \\
(0.00)\end{array}$ & $\begin{array}{l}-0.0831^{* * *} \\
(0.00)\end{array}$ \\
\hline Population Density & $\begin{array}{l}-0.1839^{* \star *} \\
(0.00)\end{array}$ & $\begin{array}{c}-0.0394 \\
(0.29)\end{array}$ & $\begin{array}{l}-0.2233^{* \star \star} \\
(0.00)\end{array}$ \\
\hline Area & $\begin{array}{l}-0.1955^{\star * *} \\
(0.00)\end{array}$ & $\begin{array}{c}-0.0742^{*} \\
(0.06)\end{array}$ & $\begin{array}{l}-0.2697^{* * \star} \\
(0.00)\end{array}$ \\
\hline NAIX & $\begin{array}{c}0.0003 \\
(0.59)\end{array}$ & $\begin{array}{l}-0.0020^{* *} \\
(0.03)\end{array}$ & $\begin{array}{l}-0.0017^{* *} \\
(0.04)\end{array}$ \\
\hline R-squared & \multicolumn{3}{|l|}{0.8257} \\
\hline$\rho$ & \multicolumn{3}{|l|}{$\begin{array}{l}0.5297^{* * *} \\
(0.0000)\end{array}$} \\
\hline
\end{tabular}

p-levels are reported in parenthesis.

$* * *$ Significant at the $99 \%$ level

** Significant at the $95 \%$ level

*Significant at the $90 \%$ level 
Table 4.5: Direct, Indirect and Total Effects Estimates with Contiguity Weight Matrix and a Relative Measure of Coal Dependence

\begin{tabular}{|c|c|c|c|}
\hline Variable & Direct Effects & Indirect Effects & Total Effects \\
\hline $\begin{array}{l}\text { Coal Production per Income } \\
\text { (\$) }\end{array}$ & $\begin{array}{l}0.0079^{* * *} \\
(0.00)\end{array}$ & $\begin{array}{l}0.0081 \\
(0.50)\end{array}$ & $\begin{array}{l}0.0161 \\
(0.22)\end{array}$ \\
\hline Initial Income & $\begin{array}{l}0.5849^{* * *} \\
(0.00)\end{array}$ & $\begin{array}{c}-0.0224 \\
(0.57)\end{array}$ & $\begin{array}{l}0.5625^{* \star *} \\
(0.00)\end{array}$ \\
\hline $\begin{array}{l}\text { Agriculture, Forestry, } \\
\text { Fisheries, Mining Emp. }\end{array}$ & $\begin{array}{l}-0.0142^{* * *} \\
(0.00)\end{array}$ & $\begin{array}{l}-0.0238^{* * *} \\
(0.00)\end{array}$ & $\begin{array}{l}-0.0379^{* \star *} \\
(0.00)\end{array}$ \\
\hline Construction Emp. & $\begin{array}{l}0.0040 \\
(0.41)\end{array}$ & $\begin{array}{l}-0.0239^{*} \\
(0.08)\end{array}$ & $\begin{array}{c}-0.0199 \\
(0.16)\end{array}$ \\
\hline Manufacturing Emp. & $\begin{array}{c}-0.0034 \\
(0.27)\end{array}$ & $\begin{array}{c}0.0042 \\
(0.55)\end{array}$ & $\begin{array}{l}0.0008^{*} \\
(0.09)\end{array}$ \\
\hline $\begin{array}{l}\text { Transportation, } \\
\text { Communication and other } \\
\text { Public Utilities Emp. }\end{array}$ & $\begin{array}{c}0.0033 \\
(0.42)\end{array}$ & $\begin{array}{l}-0.0371^{* *} \\
(0.01)\end{array}$ & $\begin{array}{l}-0.0338^{* *} \\
(0.03)\end{array}$ \\
\hline $\begin{array}{l}\text { Wholesale and Retail Trade } \\
\text { Emp. }\end{array}$ & $\begin{array}{c}0.0042 \\
(0.62)\end{array}$ & $\begin{array}{l}0.0621^{* *} \\
(0.04)\end{array}$ & $\begin{array}{l}0.0662^{*} \\
(0.05)\end{array}$ \\
\hline $\begin{array}{l}\text { Finance, Insurance and Real } \\
\text { Estate Emp. }\end{array}$ & $\begin{array}{l}0.0251^{* * *} \\
(0.00)\end{array}$ & $\begin{array}{l}0.0170 \\
(0.32)\end{array}$ & $\begin{array}{l}0.0421^{* *} \\
(0.02)\end{array}$ \\
\hline $\begin{array}{l}\text { Business and Repair } \\
\text { Services Emp. }\end{array}$ & $\begin{array}{l}0.0154^{* \star *} \\
(0.00)\end{array}$ & $\begin{array}{l}0.0087 \\
(0.53)\end{array}$ & $\begin{array}{l}0.0241 \\
(0.12)\end{array}$ \\
\hline $\begin{array}{l}\text { Personal, Entertainment and } \\
\text { Recreation Services Emp. }\end{array}$ & $\begin{array}{l}0.0092^{* *} \\
(0.03)\end{array}$ & $\begin{array}{l}0.0186 \\
(0.20)\end{array}$ & $\begin{array}{l}0.0278^{*} \\
(0.08)\end{array}$ \\
\hline Health Services Emp. & $\begin{array}{l}0.0100^{* \star \star} \\
(0.00)\end{array}$ & $\begin{array}{l}0.0163 \\
(0.18)\end{array}$ & $\begin{array}{l}0.0263^{*} \\
(0.05)\end{array}$ \\
\hline Educational Services Emp. & $\begin{array}{l}-0.0348^{* * *} \\
(0.00)\end{array}$ & $\begin{array}{l}0.0419 \\
(0.10)\end{array}$ & $\begin{array}{l}0.0071 \\
(0.80)\end{array}$ \\
\hline $\begin{array}{l}\text { Other Professional and } \\
\text { Related Services Emp. }\end{array}$ & $\begin{array}{l}0.0050^{*} \\
(0.07)\end{array}$ & $\begin{array}{c}-0.0041 \\
(0.79)\end{array}$ & $\begin{array}{l}0.0009 \\
(0.96)\end{array}$ \\
\hline $\begin{array}{l}\text { Federal Government } \\
\text { Employment }\end{array}$ & $\begin{array}{c}0.0032 \\
(0.21)\end{array}$ & $\begin{array}{l}0.0207^{* * *} \\
(0.00)\end{array}$ & $\begin{array}{l}0.0239^{* * *} \\
(0.00)\end{array}$ \\
\hline $\begin{array}{l}\text { State Government } \\
\text { Employment }\end{array}$ & $\begin{array}{l}-0.0123^{* * *} \\
(0.00)\end{array}$ & $\begin{array}{l}0.0063 \\
(0.46)\end{array}$ & $\begin{array}{c}-0.0060 \\
(0.50)\end{array}$ \\
\hline $\begin{array}{l}\text { Local Government } \\
\text { Employment }\end{array}$ & $\begin{array}{l}-0.0131^{*} \\
(0.09)\end{array}$ & $\begin{array}{c}0.0038 \\
(0.86)\end{array}$ & $\begin{array}{c}-0.0093 \\
(0.67)\end{array}$ \\
\hline Self Employment & $\begin{array}{l}0.0815^{* \star *} \\
(0.00)\end{array}$ & $\begin{array}{c}-0.0051 \\
(0.70)\end{array}$ & $\begin{array}{l}0.0764^{* \star *} \\
(0.00)\end{array}$ \\
\hline Poverty & $\begin{array}{l}-0.0258^{* \star *} \\
(0.00)\end{array}$ & $\begin{array}{l}0.0146 \\
(0.20)\end{array}$ & $\begin{array}{c}-0.0111 \\
(0.14)\end{array}$ \\
\hline Human Capital & $\begin{array}{l}0.1139^{* * *} \\
(0.00)\end{array}$ & $\begin{array}{l}-0.0398^{*} \\
(0.07)\end{array}$ & $\begin{array}{l}0.0741^{* \star \star} \\
(0.00)\end{array}$ \\
\hline College town Dummy & $\begin{array}{l}-0.0196^{* \star *} \\
(0.00)\end{array}$ & $\begin{array}{l}-0.0657^{* \star *} \\
(0.00)\end{array}$ & $\begin{array}{l}-0.0853^{* * *} \\
(0.00)\end{array}$ \\
\hline Population Density & $\begin{array}{l}-0.1916^{* \star *} \\
(0.00)\end{array}$ & $\begin{array}{c}-0.0551 \\
(0.14)\end{array}$ & $\begin{array}{l}-0.2468^{* \star *} \\
(0.00)\end{array}$ \\
\hline Area & $\begin{array}{l}-0.2027^{* \star *} \\
(0.00)\end{array}$ & $\begin{array}{l}-0.0889^{* *} \\
(0.02)\end{array}$ & $\begin{array}{l}-0.2916^{* \star \star} \\
(0.00)\end{array}$ \\
\hline NAIX & $\begin{array}{l}0.0003 \\
(0.53)\end{array}$ & $\begin{array}{l}-0.0021^{* *} \\
(0.03)\end{array}$ & $\begin{array}{l}-0.0018^{* *} \\
(0.03)\end{array}$ \\
\hline R-squared & \multicolumn{3}{|l|}{0.8258} \\
\hline$\rho$ & \multicolumn{3}{|l|}{$\begin{array}{l}0.5300^{\star \star *} \\
(0.0000)\end{array}$} \\
\hline
\end{tabular}

p-levels are reported in parenthesis.

$* * *$ Significant at the $99 \%$ level

**Significant at the $95 \%$ level

*Significant at the $90 \%$ level 
Table 4.6: Direct, Indirect and Total Effects Estimates with 14 Nearest Neighbors and an Absolute Measure of Coal Abundance

\begin{tabular}{|c|c|c|c|}
\hline Variable & Direct Effects & Indirect Effects & Total Effects \\
\hline $\begin{array}{l}\text { Coal Production per Capita } \\
\text { (\$) }\end{array}$ & $\begin{array}{c}-0.0001 \\
(0.92)\end{array}$ & $\begin{array}{c}-0.0022 \\
(0.50)\end{array}$ & $\begin{array}{c}-0.0022 \\
(0.48)\end{array}$ \\
\hline Initial Income & $\begin{array}{l}0.5917^{* * *} \\
(0.00)\end{array}$ & $\begin{array}{c}-0.0055 \\
(0.93)\end{array}$ & $\begin{array}{l}0.5862^{* * *} \\
(0.00)\end{array}$ \\
\hline $\begin{array}{l}\text { Agriculture, Forestry, } \\
\text { Fisheries, Mining Emp. }\end{array}$ & $\begin{array}{l}-0.0127^{* * *} \\
(0.00)\end{array}$ & $\begin{array}{c}-0.0195 \\
(0.15)\end{array}$ & $\begin{array}{l}-0.0322^{* *} \\
(0.02)\end{array}$ \\
\hline Construction Emp. & $\begin{array}{l}0.0056 \\
(0.25)\end{array}$ & $\begin{array}{l}-0.0085 \\
(0.70)\end{array}$ & $\begin{array}{c}-0.0030 \\
(0.90)\end{array}$ \\
\hline Manufacturing Emp. & $\begin{array}{l}-0.0044^{\star *} \\
(0.03)\end{array}$ & $\begin{array}{c}0.0073 \\
(0.50)\end{array}$ & $\begin{array}{l}0.0029^{*} \\
(0.09)\end{array}$ \\
\hline $\begin{array}{l}\text { Transportation, } \\
\text { Communication and other } \\
\text { Public Utilities Emp. }\end{array}$ & $\begin{array}{c}0.0062 \\
(0.13)\end{array}$ & $\begin{array}{c}-0.0385 \\
(0.13)\end{array}$ & $\begin{array}{c}-0.0322 \\
(0.22)\end{array}$ \\
\hline $\begin{array}{l}\text { Wholesale and Retail Trade } \\
\text { Emp. }\end{array}$ & $\begin{array}{c}-0.0048 \\
(0.55)\end{array}$ & $\begin{array}{l}0.0786 \\
(0.20)\end{array}$ & $\begin{array}{l}0.0737 \\
(0.25)\end{array}$ \\
\hline $\begin{array}{l}\text { Finance, Insurance and Real } \\
\text { Estate Emp. }\end{array}$ & $\begin{array}{l}0.0254^{* * *} \\
(0.00)\end{array}$ & $\begin{array}{l}0.0565 \\
(0.10)\end{array}$ & $\begin{array}{l}0.0819^{* *} \\
(0.02)\end{array}$ \\
\hline $\begin{array}{l}\text { Business and Repair } \\
\text { Services Emp. }\end{array}$ & $\begin{array}{l}0.0196^{* \star *} \\
(0.00)\end{array}$ & $\begin{array}{c}-0.0403 \\
(0.15)\end{array}$ & $\begin{array}{c}-0.0207 \\
(0.47)\end{array}$ \\
\hline $\begin{array}{l}\text { Personal, Entertainment and } \\
\text { Recreation Services Emp. }\end{array}$ & $\begin{array}{l}0.0053 \\
(0.21)\end{array}$ & $\begin{array}{l}0.0197 \\
(0.46)\end{array}$ & $\begin{array}{c}0.0250 \\
(0.37)\end{array}$ \\
\hline Health Services Emp. & $\begin{array}{l}0.0093^{* *} \\
(0.01)\end{array}$ & $\begin{array}{l}0.0241 \\
(0.28)\end{array}$ & $\begin{array}{c}0.0334 \\
(0.15)\end{array}$ \\
\hline Educational Services Emp. & $\begin{array}{l}-0.0345^{* \star *} \\
(0.00)\end{array}$ & $\begin{array}{l}0.1054^{* *} \\
(0.03)\end{array}$ & $\begin{array}{l}0.0708 \\
(0.17)\end{array}$ \\
\hline $\begin{array}{l}\text { Other Professional and } \\
\text { Related Services Emp. }\end{array}$ & $\begin{array}{l}0.0032 \\
(0.43)\end{array}$ & $\begin{array}{c}-0.0070 \\
(0.81)\end{array}$ & $\begin{array}{c}-0.0038 \\
(0.90)\end{array}$ \\
\hline $\begin{array}{l}\text { Federal Government } \\
\text { Employment }\end{array}$ & $\begin{array}{l}0.0020 \\
(0.42)\end{array}$ & $\begin{array}{l}0.0396^{\star \star \star} \\
(0.00)\end{array}$ & $\begin{array}{l}0.0416^{* * *} \\
(0.00)\end{array}$ \\
\hline $\begin{array}{l}\text { State Government } \\
\text { Employment }\end{array}$ & $\begin{array}{l}-0.0146^{* \star *} \\
(0.00)\end{array}$ & $\begin{array}{l}0.0009 \\
(0.95)\end{array}$ & $\begin{array}{c}-0.0136 \\
(0.41)\end{array}$ \\
\hline $\begin{array}{l}\text { Local Government } \\
\text { Employment }\end{array}$ & $\begin{array}{l}-0.0133^{*} \\
(0.08)\end{array}$ & $\begin{array}{c}-0.0390 \\
(0.29)\end{array}$ & $\begin{array}{c}-0.0522 \\
(0.16)\end{array}$ \\
\hline Self Employment & $\begin{array}{l}0.0794^{* * *} \\
(0.00)\end{array}$ & $\begin{array}{c}-0.0115 \\
(0.61)\end{array}$ & $\begin{array}{l}0.0678^{* * *} \\
(0.00)\end{array}$ \\
\hline Poverty & $\begin{array}{l}-0.0277^{* * *} \\
(0.00)\end{array}$ & $\begin{array}{l}0.0159 \\
(0.23)\end{array}$ & $\begin{array}{c}-0.0118 \\
(0.30)\end{array}$ \\
\hline Human Capital & $\begin{array}{l}0.1141^{* * *} \\
(0.00)\end{array}$ & $\begin{array}{l}-0.0730^{*} \\
(0.06)\end{array}$ & $\begin{array}{l}0.0410 \\
(0.30)\end{array}$ \\
\hline College town Dummy & $\begin{array}{l}-0.0179^{* * *} \\
(0.00)\end{array}$ & $\begin{array}{l}-0.1428^{* * *} \\
(0.00)\end{array}$ & $\begin{array}{l}-0.1607^{* * *} \\
(0.00)\end{array}$ \\
\hline Population Density & $\begin{array}{l}-0.1773^{* \star *} \\
(0.00)\end{array}$ & $\begin{array}{c}-0.0797 \\
(0.22)\end{array}$ & $\begin{array}{l}-0.2570^{* * *} \\
(0.00)\end{array}$ \\
\hline Area & $\begin{array}{l}-0.1906^{* \star *} \\
(0.00)\end{array}$ & $\begin{array}{c}-0.1093 \\
(0.11)\end{array}$ & $\begin{array}{l}-0.2999^{* * *} \\
(0.00)\end{array}$ \\
\hline NAIX & $\begin{array}{l}0.0007 \\
(0.18)\end{array}$ & $\begin{array}{l}-0.0025^{*} \\
(0.08)\end{array}$ & $\begin{array}{c}-0.0019 \\
(0.18)\end{array}$ \\
\hline R-squared & \multicolumn{3}{|l|}{0.8186} \\
\hline$\rho$ & \multicolumn{3}{|l|}{$\begin{array}{l}0.6494^{* * *} \\
(0.00)\end{array}$} \\
\hline
\end{tabular}

p-levels are reported in parenthesis.

$* * *$ Significant at the $99 \%$ level

$* *$ Significant at the $95 \%$ level

*Significant at the $90 \%$ level 
Table 4.7: Direct, Indirect and Total Effects Estimates with 14 Nearest Neighbors and a Relative Measure of Coal Dependence

\begin{tabular}{|c|c|c|c|}
\hline Variable & Direct Effects & Indirect Effects & Total Effects \\
\hline $\begin{array}{l}\text { Coal Production per Income } \\
\text { (\$) }\end{array}$ & $\begin{array}{l}0.0077^{* * *} \\
(0.00)\end{array}$ & $\begin{array}{c}0.0452^{*} \\
(0.06)\end{array}$ & $\begin{array}{l}0.0529^{* *} \\
(0.03)\end{array}$ \\
\hline Initial Income & $\begin{array}{l}0.5878^{* * *} \\
(0.00)\end{array}$ & $\begin{array}{c}-0.0230 \\
(0.73)\end{array}$ & $\begin{array}{l}0.5648^{* * *} \\
(0.00)\end{array}$ \\
\hline $\begin{array}{l}\text { Agriculture, Forestry, } \\
\text { Fisheries, Mining Emp. }\end{array}$ & $\begin{array}{l}-0.0140^{* * *} \\
(0.00)\end{array}$ & $\begin{array}{c}-0.0254^{*} \\
(0.07)\end{array}$ & $\begin{array}{l}-0.0395^{* *} \\
(0.00)\end{array}$ \\
\hline Construction Emp. & $\begin{array}{l}0.0050 \\
(0.23) \\
\end{array}$ & $\begin{array}{l}-0.0130 \\
(0.56) \\
\end{array}$ & $\begin{array}{c}-0.0077 \\
(0.73) \\
\end{array}$ \\
\hline Manufacturing Emp. & $\begin{array}{c}-0.0027 \\
(0.34)\end{array}$ & $\begin{array}{c}0.0157 \\
(0.15)\end{array}$ & $\begin{array}{c}0.0129 \\
(0.14)\end{array}$ \\
\hline $\begin{array}{l}\text { Transportation, } \\
\text { Communication and other } \\
\text { Public Utilities Emp. }\end{array}$ & $\begin{array}{c}0.0050 \\
(0.23)\end{array}$ & $\begin{array}{c}-0.0487^{*} \\
(0.05)\end{array}$ & $\begin{array}{c}-0.0437^{*} \\
(0.09)\end{array}$ \\
\hline $\begin{array}{l}\text { Wholesale and Retail Trade } \\
\text { Emp. }\end{array}$ & $\begin{array}{c}-0.0034 \\
(0.68)\end{array}$ & $\begin{array}{l}0.1019^{*} \\
(0.09)\end{array}$ & $\begin{array}{l}0.0884 \\
(0.16)\end{array}$ \\
\hline $\begin{array}{l}\text { Finance, Insurance and Real } \\
\text { Estate Emp. }\end{array}$ & $\begin{array}{l}0.0261^{* * *} \\
(0.00)\end{array}$ & $\begin{array}{c}0.0642^{*} \\
(0.06)\end{array}$ & $\begin{array}{l}0.0903^{* *} \\
(0.01)\end{array}$ \\
\hline $\begin{array}{l}\text { Business and Repair } \\
\text { Services Emp. }\end{array}$ & $\begin{array}{l}0.0207^{* \star *} \\
(0.00)\end{array}$ & $\begin{array}{c}-0.0245 \\
(0.37)\end{array}$ & $\begin{array}{c}-0.0038 \\
(0.89)\end{array}$ \\
\hline $\begin{array}{l}\text { Personal, Entertainment and } \\
\text { Recreation Services Emp. }\end{array}$ & $\begin{array}{l}0.0049 \\
(0.25)\end{array}$ & $\begin{array}{l}0.0219 \\
(0.42)\end{array}$ & $\begin{array}{l}0.0268 \\
(0.34)\end{array}$ \\
\hline Health Services Emp. & $\begin{array}{l}0.0094^{* *} \\
(0.01)\end{array}$ & $\begin{array}{l}0.0213 \\
(0.34)\end{array}$ & $\begin{array}{l}0.0307 \\
(0.18)\end{array}$ \\
\hline Educational Services Emp. & $\begin{array}{l}-0.0357^{* * *} \\
(0.00)\end{array}$ & $\begin{array}{l}0.0933^{*} \\
(0.06)\end{array}$ & $\begin{array}{l}0.0575 \\
(0.27)\end{array}$ \\
\hline $\begin{array}{l}\text { Other Professional and } \\
\text { Related Services Emp. }\end{array}$ & $\begin{array}{l}0.0029 \\
(0.47)\end{array}$ & $\begin{array}{c}-0.0121 \\
(0.68)\end{array}$ & $\begin{array}{c}-0.0093 \\
(0.77)\end{array}$ \\
\hline $\begin{array}{l}\text { Federal Government } \\
\text { Employment }\end{array}$ & $\begin{array}{l}0.0026 \\
(0.29)\end{array}$ & $\begin{array}{l}0.0397^{* \star *} \\
(0.00)\end{array}$ & $\begin{array}{l}0.0422^{* \star *} \\
(0.00)\end{array}$ \\
\hline $\begin{array}{l}\text { State Government } \\
\text { Employment }\end{array}$ & $\begin{array}{l}-0.0136^{* \star *} \\
(0.00)\end{array}$ & $\begin{array}{l}0.0064 \\
(0.69)\end{array}$ & $\begin{array}{c}-0.0071 \\
(0.67)\end{array}$ \\
\hline $\begin{array}{l}\text { Local Government } \\
\text { Employment }\end{array}$ & $\begin{array}{c}-0.0116 \\
(0.10)\end{array}$ & $\begin{array}{c}-0.0179 \\
(0.62)\end{array}$ & $\begin{array}{c}-0.0295 \\
(0.43)\end{array}$ \\
\hline Self Employment & $\begin{array}{l}0.0819^{* \star *} \\
(0.00)\end{array}$ & $\begin{array}{c}-0.0042 \\
(0.85)\end{array}$ & $\begin{array}{l}0.0777^{* * *} \\
(0.00)\end{array}$ \\
\hline Poverty & $\begin{array}{l}-0.0279^{* * *} \\
(0.00)\end{array}$ & $\begin{array}{l}0.0170 \\
(0.19)\end{array}$ & $\begin{array}{c}-0.0109 \\
(0.33)\end{array}$ \\
\hline Human Capital & $\begin{array}{l}0.1147^{* \star *} \\
(0.00)\end{array}$ & $\begin{array}{l}-0.0683^{*} \\
(0.08)\end{array}$ & $\begin{array}{l}0.0464 \\
(0.25)\end{array}$ \\
\hline College town Dummy & $\begin{array}{l}-0.0183^{* * *} \\
(0.00)\end{array}$ & $\begin{array}{l}-0.1466^{* * *} \\
(0.00)\end{array}$ & $\begin{array}{l}-0.1649^{* * *} \\
(0.00)\end{array}$ \\
\hline Population Density & $\begin{array}{l}-0.1843^{* * *} \\
(0.00)\end{array}$ & $\begin{array}{l}-0.1297^{*} \\
(0.05)\end{array}$ & $\begin{array}{l}-0.3140^{* * *} \\
(0.00)\end{array}$ \\
\hline Area & $\begin{array}{l}-0.1974^{* \star *} \\
(0.00)\end{array}$ & $\begin{array}{l}-0.1538^{* *} \\
(0.03)\end{array}$ & $\begin{array}{l}-0.3512^{* \star \star} \\
(0.00)\end{array}$ \\
\hline NAIX & $\begin{array}{l}0.0007 \\
(0.19)\end{array}$ & $\begin{array}{l}-0.0030^{* *} \\
(0.03)\end{array}$ & $\begin{array}{l}-0.0023^{*} \\
(0.08)\end{array}$ \\
\hline R-squared & \multicolumn{3}{|l|}{0.8188} \\
\hline$\rho$ & \multicolumn{3}{|l|}{$\begin{array}{l}0.6519^{* \star \star} \\
(0.00)\end{array}$} \\
\hline
\end{tabular}

p-levels are reported in parenthesis.

$* * *$ Significant at the $99 \%$ level

**Significant at the $95 \%$ level

*Significant at the $90 \%$ level 
Table 4.8: OLS Results with an Absolute and a Relative Measure of Coal Abundance

\begin{tabular}{|c|c|c|}
\hline Variable & OLS(1) & OLS(2) \\
\hline $\begin{array}{l}\text { Coal Production per Capita } \\
\text { (\$) }\end{array}$ & $\begin{array}{l}0.0020^{* *} \\
(0.01)\end{array}$ & - \\
\hline $\begin{array}{l}\text { Coal Production per Income } \\
\text { (\$) }\end{array}$ & - & $\begin{array}{l}-0.0036^{* *} \\
(0.02)\end{array}$ \\
\hline Initial Income & $\begin{array}{l}0.4387^{* * *} \\
(0.00)\end{array}$ & $\begin{array}{l}0.4369^{* \star *} \\
(0.00)\end{array}$ \\
\hline $\begin{array}{l}\text { Agriculture, Forestry, } \\
\text { Fisheries, Mining Emp. }\end{array}$ & $\begin{array}{l}-0.0180^{* * *} \\
(0.00)\end{array}$ & $\begin{array}{l}-0.0203^{* * *} \\
(0.00)\end{array}$ \\
\hline Construction Emp. & $\begin{array}{l}-0.0147^{\star \star} \\
(0.01)\end{array}$ & $\begin{array}{l}-0.0155^{\star \star \star} \\
(0.00)\end{array}$ \\
\hline Manufacturing Emp. & $\begin{array}{l}-0.0104^{* \star *} \\
(0.00)\end{array}$ & $\begin{array}{l}-0.0084^{* \star *} \\
(0.00)\end{array}$ \\
\hline $\begin{array}{l}\text { Transportation, } \\
\text { Communication and other } \\
\text { Public Utilities Emp. }\end{array}$ & $\begin{array}{c}-0.0033 \\
(0.51)\end{array}$ & $\begin{array}{c}-0.0049 \\
(0.33)\end{array}$ \\
\hline $\begin{array}{l}\text { Wholesale and Retail Trade } \\
\text { Emp. }\end{array}$ & $\begin{array}{l}-0.0226^{* *} \\
(0.02)\end{array}$ & $\begin{array}{l}-0.0202^{* *} \\
(0.04)\end{array}$ \\
\hline $\begin{array}{l}\text { Finance, Insurance and Real } \\
\text { Estate Emp. }\end{array}$ & $\begin{array}{l}0.0351^{* \star *} \\
(0.00)\end{array}$ & $\begin{array}{l}0.0360^{* \star *} \\
(0.00)\end{array}$ \\
\hline $\begin{array}{l}\text { Business and Repair } \\
\text { Services Emp. }\end{array}$ & $\begin{array}{l}0.0113^{* *} \\
(0.01)\end{array}$ & $\begin{array}{l}0.0127^{* *} \\
(0.01)\end{array}$ \\
\hline $\begin{array}{l}\text { Personal, Entertainment and } \\
\text { Recreation Services Emp. }\end{array}$ & $\begin{array}{l}0.0258^{* \star \star} \\
(0.00)\end{array}$ & $\begin{array}{l}0.0259^{\star \star \star} \\
(0.00)\end{array}$ \\
\hline Health Services Emp. & $\begin{array}{l}-0.0076^{*} \\
(0.06)\end{array}$ & $\begin{array}{l}-0.0078^{*} \\
(0.05)\end{array}$ \\
\hline Educational Services Emp. & $\begin{array}{l}-0.0277^{* * *} \\
(0.00)\end{array}$ & $\begin{array}{l}-0.0291^{* * *} \\
(0.00)\end{array}$ \\
\hline $\begin{array}{l}\text { Other Professional and } \\
\text { Related Services Emp. }\end{array}$ & $\begin{array}{l}0.0125^{* *} \\
(0.01)\end{array}$ & $\begin{array}{l}0.0125^{* *} \\
(0.01)\end{array}$ \\
\hline $\begin{array}{l}\text { Federal Government } \\
\text { Employment }\end{array}$ & $\begin{array}{l}-0.0008 \\
(0.78)\end{array}$ & $\begin{array}{c}-0.0007 \\
(0.81)\end{array}$ \\
\hline $\begin{array}{l}\text { State Government } \\
\text { Employment }\end{array}$ & $\begin{array}{l}-0.0117^{* * *} \\
(0.00)\end{array}$ & $\begin{array}{l}-0.0112^{* * *} \\
(0.000)\end{array}$ \\
\hline $\begin{array}{l}\text { Local Government } \\
\text { Employment }\end{array}$ & $\begin{array}{c}-0.0101 \\
(0.20)\end{array}$ & $\begin{array}{c}-0.0133 \\
(0.10)\end{array}$ \\
\hline Self Employment & $\begin{array}{l}0.0849^{* * \star} \\
(0.00)\end{array}$ & $\begin{array}{l}0.0884^{* * *} \\
(0.00)\end{array}$ \\
\hline Poverty & $\begin{array}{l}-0.0387^{\star \star *} \\
(0.00)\end{array}$ & $\begin{array}{l}-0.1836^{* \star *} \\
(0.00)\end{array}$ \\
\hline Human Capital & $\begin{array}{l}0.1100^{* * *} \\
(0.00)\end{array}$ & $\begin{array}{l}0.1124^{* * *} \\
(0.00)\end{array}$ \\
\hline College town Dummy & $\begin{array}{l}-0.0299^{* * *} \\
(0.00)\end{array}$ & $\begin{array}{l}-0.0304^{* \star *} \\
(0.00)\end{array}$ \\
\hline Population Density & $\begin{array}{c}-0.1528^{\star * *} \\
(0.00)\end{array}$ & $\begin{array}{c}-0.1644^{\star \star *} \\
(0.00)\end{array}$ \\
\hline Area & $\begin{array}{c}-0.1945^{\star * *} \\
(0.00)\end{array}$ & $\begin{array}{c}-0.2053^{\star \star \star} \\
(0.00)\end{array}$ \\
\hline NAIX & $\begin{array}{l}-0.0017^{* * *} \\
(0.00)\end{array}$ & $\begin{array}{l}-0.0017^{* \star *} \\
(0.00)\end{array}$ \\
\hline R-squared & 0.8287 & 0.8284 \\
\hline
\end{tabular}

p-levels are reported in parenthesis.

$* * *$ Significant at the $99 \%$ level

$* *$ Significant at the $95 \%$ level

*Significant at the $90 \%$ level 
Indirect effects estimates presented in the above tables represent spatial spillovers and capture related-county effects associated with changes in own-county level characteristics. LeSage and Pace (2009) explain that indirect effects estimates can be interpreted in two different ways. The first interpretation is named as the average total impact on an observation. This interpretation captures how a change in the initial level of explanatory variable characteristics of all counties by some constant amount would change the income level of a typical county. The second interpretation is named as the average total impact from an observation, which captures the cumulative impact of a change in own-county initial level of explanatory variable characteristics averaged over all other regions. The counties that are closely related to own-county would experience greater income effects, while the ones that are loosely related would have smaller impacts.

Total effect estimates are the sum of direct and indirect estimates. As depicted in Table 4.5, the positive magnitude of total impact of initial income level suggests that higher income levels lead to higher current levels of county income.

Direct, indirect and total effects estimates of the absolute coal abundance variable are not significant in either model specification. On the other hand, the direct effects estimates of the relative coal dependence variable are positive and significant in both specifications. These results are in stark contrast to the OLS regression results displayed on Table 4.8. The OLS results suggest a negative significant relationship between the relative coal dependence variable and county growth, and a positive insignificant relationship between the absolute coal abundance variable and county growth. The OLS results are in line with the strand of cross-country growth literature that suggests that 
switching from relative measures of resource dependence to absolute measures of resource abundance makes the resource curse disappear across countries (Stijns, 2005; Brunnschweiler, 2007). However, our results suggest that accounting for spatial dependence in growth regressions results in reversed signs of the absolute and the relative coal abundance variables. After accounting for spatial dependence, the relative coal dependence variable turns out to be positive and significant, while the absolute coal abundance variable turns out to have a negative sign. This implies that controlling for spatial dependence reverses the coal curse. Institutions and rent seeking have often been blamed for the presence of a resource curse. This finding may suggest that within the counties that share the same institutional structure, coal abundant counties may be better off in economic growth.

In addition to the coal abundance and dependence variables, several other variables' sign change when spatial dependence is introduced. These variables are employment in construction industries, wholesale and retail trade, health services, federal government employment, and natural amenities index.

As explained earlier, spatial growth regression models produce estimates and inferences that are conditional on the spatial weight matrix used. Employing different spatial weight matrices may change the dispersion of estimated coefficients. This may lead to ambiguity concerning the identification of important growth factors. This is reflected on our results. For instance, while only the direct effect estimate of the coal dependence variable is significant in the first specification, all effects estimates (direct, indirect and total effects) of the coal dependence variable are significant in the second specification. This ambiguity also holds for variables such as human capital, local 
government employment, natural amenities index, and employment in industries such as transportation and communication, entertainment and recreational services, and wholesale and retail trade. Employing Bayesian model averaging, discussed in the next section, will produce model averaged estimates and inferences to clarify the ambiguity pertaining to the significance of these variables.

\subsubsection{Results of the Bayesian Model Averaging}

Monte Carlo Markov Chain model composition with the Bayesian model averaging is run. Table 4.9 shows the five highest posterior probability models and the variables appearing in these models. Variables that appear in each model are assigned a " 1 " and those that do not appear are assigned a " 0 ". The last column shows the probability that each variable should enter the model based on frequency of appearance of each variable in the top 1,000 models.

Although relative and absolute measures of coal abundance do not appear in any of the top five models, they appear in $17 \%$ and $4 \%$ of the top 1,000 models, indicated by the inclusion probabilities of 17 percent and 4 percent, respectively. The probabilities of inclusion for their spatial lags are 7 percent and 4 percent respectively. Compared with the absolute measure of coal abundance, the relative measure of coal abundance has higher inclusion probabilities for both itself and its spatial lag. 
Table 4.9: High-probability models

\begin{tabular}{|c|c|c|c|c|c|c|}
\hline Variable names & 5 & 4 & 3 & 2 & 1 & Probs. \\
\hline Initial income & 1 & 1 & 1 & 1 & 1 & 0.9816 \\
\hline $\begin{array}{l}\text { Agriculture, forestry, fisheries, mining } \\
\text { emp. }\end{array}$ & 1 & 1 & 1 & 1 & 1 & 0.8654 \\
\hline Construction emp. & 0 & 0 & 0 & 0 & 0 & 0.3026 \\
\hline Manufacturing emp. & 1 & 1 & 1 & 1 & 1 & 0.9608 \\
\hline $\begin{array}{l}\text { Transportation, communication and } \\
\text { other public utilities emp. }\end{array}$ & 0 & 0 & 0 & 0 & 0 & 0.0262 \\
\hline Wholesale and retail trade emp. & 0 & 0 & 0 & 0 & 0 & 0.0550 \\
\hline $\begin{array}{l}\text { Finance, insurance and real estate } \\
\text { employment }\end{array}$ & 1 & 1 & 1 & 1 & 1 & 0.9560 \\
\hline $\begin{array}{l}\text { Business and repair services } \\
\text { employment }\end{array}$ & 0 & 0 & 0 & 0 & 0 & 0.2774 \\
\hline $\begin{array}{l}\text { Personal, entertainment and recreation } \\
\text { services emp. }\end{array}$ & 0 & 0 & 0 & 0 & 0 & 0.0998 \\
\hline Health services emp. & 0 & 0 & 0 & 0 & 0 & 0.0456 \\
\hline Educational services emp. & 1 & 1 & 1 & 1 & 1 & 0.9620 \\
\hline $\begin{array}{l}\text { Other professional and related services } \\
\text { emp. }\end{array}$ & 1 & 0 & 0 & 0 & 0 & 0.3758 \\
\hline Federal government employment & 0 & 0 & 0 & 0 & 0 & 0.1356 \\
\hline State government employment & 1 & 1 & 1 & 1 & 1 & 0.9568 \\
\hline Local government employment & 0 & 0 & 0 & 0 & 0 & 0.0462 \\
\hline Self employment & 1 & 1 & 1 & 1 & 1 & 0.9692 \\
\hline Poverty & 1 & 1 & 1 & 1 & 1 & 0.9642 \\
\hline NAIX & 0 & 0 & 0 & 0 & 0 & 0.0526 \\
\hline Human capital & 1 & 1 & 1 & 1 & 1 & 0.9670 \\
\hline Population density & 1 & 1 & 1 & 1 & 1 & 0.9614 \\
\hline Area & 1 & 1 & 1 & 1 & 1 & 0.9696 \\
\hline Collegetown dummy & 1 & 1 & 1 & 1 & 1 & 0.9390 \\
\hline $\begin{array}{l}\text { Coal value per income (Relative } \\
\text { measure) }\end{array}$ & 0 & 0 & 0 & 0 & 0 & 0.1714 \\
\hline $\begin{array}{l}\text { Coal value per capita (Absolute } \\
\text { measure) }\end{array}$ & 0 & 0 & 0 & 0 & 0 & 0.0406 \\
\hline
\end{tabular}


Table 4.9: High-probability models (continued)

\begin{tabular}{|c|c|c|c|c|c|c|}
\hline Variable names & 5 & 4 & 3 & 2 & 1 & Probs. \\
\hline$W$ initial income & 1 & 1 & 1 & 1 & 1 & 0.9496 \\
\hline $\begin{array}{l}W \text { agriculture, forestry, fisheries, mining } \\
\text { emp. }\end{array}$ & 0 & 0 & 0 & 0 & 0 & 0.0472 \\
\hline$W$ construction emp. & 0 & 0 & 0 & 0 & 0 & 0.0450 \\
\hline$W$ manufacturing emp. & 0 & 0 & 1 & 0 & 0 & 0.1814 \\
\hline $\begin{array}{l}W \text { transportation, communication and } \\
\text { other public utilities emp. }\end{array}$ & 0 & 0 & 0 & 0 & 0 & 0.0442 \\
\hline$W$ wholesale and retail trade emp. & 1 & 1 & 1 & 1 & 1 & 0.6150 \\
\hline $\begin{array}{l}W \text { finance, insurance and real estate } \\
\text { emp. }\end{array}$ & 0 & 0 & 0 & 0 & 0 & 0.0968 \\
\hline$W$ business and repair services emp. & 0 & 0 & 0 & 0 & 0 & 0.0498 \\
\hline $\begin{array}{l}W \text { personal, entertainment and } \\
\text { recreation services emp. }\end{array}$ & 0 & 0 & 0 & 0 & 0 & 0.3218 \\
\hline$W$ health services emp. & 0 & 0 & 0 & 0 & 0 & 0.1092 \\
\hline Weducational services emp. & 1 & 1 & 1 & 1 & 1 & 0.7484 \\
\hline $\begin{array}{l}\text { W other professional and related } \\
\text { services emp. }\end{array}$ & 0 & 0 & 0 & 0 & 0 & 0.0530 \\
\hline$W$ federal government employment & 0 & 0 & 0 & 0 & 0 & 0.0746 \\
\hline$W$ state government employment & 0 & 0 & 0 & 0 & 0 & 0.0308 \\
\hline$W$ local government employment & 0 & 0 & 0 & 0 & 0 & 0.0846 \\
\hline$W$ self employment & 1 & 1 & 1 & 1 & 1 & 0.9654 \\
\hline$W$ poverty & 1 & 0 & 1 & 0 & 0 & 0.6092 \\
\hline W NAIX & 0 & 0 & 0 & 0 & 0 & 0.2592 \\
\hline$W$ human capital & 1 & 1 & 1 & 1 & 1 & 0.9658 \\
\hline$W$ population density & 1 & 0 & 0 & 1 & 0 & 0.6084 \\
\hline$W$ area & 0 & 1 & 0 & 0 & 0 & 0.5450 \\
\hline$W$ collegetown dummy & 1 & 1 & 1 & 1 & 1 & 0.3814 \\
\hline $\begin{array}{l}W \text { coal value per income (Relative } \\
\text { measure) }\end{array}$ & 0 & 0 & 0 & 0 & 0 & 0.0714 \\
\hline $\begin{array}{l}W \text { coal value per capita (Absolute } \\
\text { measure) }\end{array}$ & 0 & 0 & 0 & 0 & 0 & 0.0338 \\
\hline Model probabilities & 0.015 & 0.032 & 0.045 & 0.098 & 0.132 & \\
\hline
\end{tabular}


Initial income and its spatial lag appear in all five models, with inclusion probabilities of 98 percent and 95 percent, respectively. Other variables that appear in all five top models with their spatial lags are human capital, self employment, educational services, and college town dummy. Employment in agricultural services, manufacturing, finance, insurance and real estate, state government, along with population density and area appear in all top five models, but the spatial lags of these variables do not appear in all five top models. One result of interest is the wholesale and retail trade employment. Although employment in wholesale and retail trade is not in the top five models, having an inclusion probability of 5.5 percent, its spatial lag is in all five top models with 62 percent inclusion probability.

Model averaged estimates, based on the 1,000 highest probability models are reported on Table 4.10 and Table 4.11. Bayesian model averaging proves fruitful as it produces model averaged estimates and inferences and clarifies the ambiguity resulting from employing different model specifications. As displayed in Table 4.10, a direct effect magnitude of 0.6186 for the initial income means that a 1 percent increase in own-county initial income would increase the income level of a typical region by 0.62 percent. Since logged levels of coal abundance, employment, human capital, poverty, population density and area are used, their direct effect estimates can be interpreted as elasticities.

Table 4.10 demonstrates that neither model averaged direct, indirect nor total effects estimates of the absolute coal abundance variable are significant. On the other hand, model averaged direct, indirect, and total effects estimates of the relative coal dependence variable are significant. The results suggest that introducing spatial dependence into growth models makes the coal curse disappear. Unlike non-spatial 
models, the results imply a significant positive relationship between relative coal abundance indicator and economic growth, and no significant association between absolute coal abundance indicator and economic growth. The results are in sharp contrast with the previous literature findings that suggest a negative association between point resources and economic growth. The results also contradict the previous findings that confirm the existence of a resource curse in the U.S. and Brunnschweiler and Bulte's (2008) results that suggest a positive relation between resource abundance and economic growth. Results from the spatial growth regressions reveal that having coal resource endowment is not a curse for own-county growth, nor it causes negative spillovers on other counties.

The rest of the results are intuitive. Own-county employment in agricultural services and manufacturing has a negative direct effect on own-county growth. However they do not exert significant spillover effects on related counties. Wholesale and retail trade imposes small positive spillovers and its total impact is positive and significant. Employment in finance, insurance and real estate and business and repair services have positive direct impact on own-county growth. Employment in educational services has a negative impact on own-county income, and positive spillovers on related counties' income. Transportation and communication, entertainment and recreational services, health services, and other services are not important growth factors. 
Table 4.10: Model Averaged Estimates with Absolute Coal Abundance Measure

\begin{tabular}{|c|c|c|c|}
\hline Variables & Direct Effects & Indirect Effects & Total Effects \\
\hline $\begin{array}{l}\text { Coal Production per Capita } \\
(\$)\end{array}$ & $\begin{array}{c}-0.0001 \\
(0.91)\end{array}$ & $\begin{array}{c}-0.0024 \\
(0.52)\end{array}$ & $\begin{array}{c}-0.0025 \\
(0.49)\end{array}$ \\
\hline Initial Income & $\begin{array}{l}0.6186^{* * *} \\
(0.00)\end{array}$ & $\begin{array}{c}-0.0199 \\
(0.81)\end{array}$ & $\begin{array}{l}0.5987^{* * *} \\
(0.00)\end{array}$ \\
\hline $\begin{array}{l}\text { Agriculture, Forestry, } \\
\text { Fisheries, Mining Emp. }\end{array}$ & $\begin{array}{l}-0.0151^{* * *} \\
(0.00)\end{array}$ & $\begin{array}{c}-0.0191 \\
(0.14)\end{array}$ & $\begin{array}{l}-0.0342^{* * *} \\
(0.00)\end{array}$ \\
\hline Construction Emp. & $\begin{array}{c}0.0078 \\
(0.39)\end{array}$ & $\begin{array}{c}-0.0139 \\
(0.56)\end{array}$ & $\begin{array}{c}-0.0061 \\
(0.85)\end{array}$ \\
\hline Manufacturing Emp. & $\begin{array}{l}-0.0071^{* *} \\
(0.04)\end{array}$ & $\begin{array}{c}0.0060 \\
(0.44)\end{array}$ & $\begin{array}{c}-0.0011^{*} \\
(0.05)\end{array}$ \\
\hline $\begin{array}{l}\text { Transportation, } \\
\text { Communication and other } \\
\text { Public Utilities Emp. }\end{array}$ & $\begin{array}{c}0.0052 \\
(0.32)\end{array}$ & $\begin{array}{c}-0.0681 \\
(0.14)\end{array}$ & $\begin{array}{c}-0.0629 \\
(0.16)\end{array}$ \\
\hline $\begin{array}{l}\text { Wholesale and Retail Trade } \\
\text { Emp. }\end{array}$ & $\begin{array}{c}0.0026 \\
(0.80)\end{array}$ & $\begin{array}{l}0.0464^{* *} \\
(0.03)\end{array}$ & $\begin{array}{l}0.0490^{* \star} \\
(0.04)\end{array}$ \\
\hline $\begin{array}{l}\text { Finance, Insurance and Real } \\
\text { Estate Emp. }\end{array}$ & $\begin{array}{l}0.0262^{* \star \star} \\
(0.00)\end{array}$ & $\begin{array}{l}0.0339 \\
(0.28)\end{array}$ & $\begin{array}{l}0.0601^{* \star} \\
(0.02)\end{array}$ \\
\hline $\begin{array}{l}\text { Business and Repair } \\
\text { Services Emp. }\end{array}$ & $\begin{array}{l}0.0158^{* \star *} \\
(0.00)\end{array}$ & $\begin{array}{c}0.0084 \\
(0.55)\end{array}$ & $\begin{array}{c}0.0242 \\
(0.67)\end{array}$ \\
\hline $\begin{array}{l}\text { Personal, Entertainment and } \\
\text { Recreation Services Emp. }\end{array}$ & $\begin{array}{l}0.0068 \\
(0.17) \\
\end{array}$ & $\begin{array}{l}0.0237 \\
(0.50) \\
\end{array}$ & $\begin{array}{c}0.0305 \\
(0.40)\end{array}$ \\
\hline Health Services Emp. & $\begin{array}{l}0.0098 \\
(0.14)\end{array}$ & $\begin{array}{c}0.0261 \\
(0.41)\end{array}$ & $\begin{array}{l}0.0359 \\
(0.25)\end{array}$ \\
\hline Educational Services Emp. & $\begin{array}{l}-0.0415^{\star \star \star} \\
(0.00)\end{array}$ & $\begin{array}{l}0.1188^{* *} \\
(0.02)\end{array}$ & $\begin{array}{l}0.0773^{\star \star} \\
(0.04)\end{array}$ \\
\hline $\begin{array}{l}\text { Other Professional and } \\
\text { Related Services Emp. }\end{array}$ & $\begin{array}{c}0.0047 \\
(0.38)\end{array}$ & $\begin{array}{c}-0.0029 \\
(0.83)\end{array}$ & $\begin{array}{l}0.0018 \\
(0.87)\end{array}$ \\
\hline $\begin{array}{l}\text { Federal Government } \\
\text { Employment }\end{array}$ & $\begin{array}{l}0.0029 \\
(0.31)\end{array}$ & $\begin{array}{l}0.0481^{* *} \\
(0.01)\end{array}$ & $\begin{array}{l}0.0510 \\
(0.11)\end{array}$ \\
\hline $\begin{array}{l}\text { State Government } \\
\text { Employment }\end{array}$ & $\begin{array}{l}-0.0193^{\star * *} \\
(0.00)\end{array}$ & $\begin{array}{l}0.0063 \\
(0.49)\end{array}$ & $\begin{array}{c}-0.0130 \\
(0.46)\end{array}$ \\
\hline $\begin{array}{l}\text { Local Government } \\
\text { Employment }\end{array}$ & $\begin{array}{c}-0.0153 \\
(0.11)\end{array}$ & $\begin{array}{c}-0.0361 \\
(0.39) \\
\end{array}$ & $\begin{array}{c}-0.0514 \\
(0.20)\end{array}$ \\
\hline Self Employment & $\begin{array}{l}0.0960^{* \star *} \\
(0.00)\end{array}$ & $\begin{array}{c}-0.0048 \\
(0.52)\end{array}$ & $\begin{array}{l}0.0912^{* * *} \\
(0.00)\end{array}$ \\
\hline Poverty & $\begin{array}{l}-0.0329^{* * *} \\
(0.00)\end{array}$ & $\begin{array}{c}0.0187 \\
(0.21)\end{array}$ & $\begin{array}{c}-0.0142 \\
(0.26)\end{array}$ \\
\hline Human Capital & $\begin{array}{l}0.1195^{\star \star *} \\
(0.00)\end{array}$ & $\begin{array}{l}-0.0768^{* *} \\
(0.01) \\
\end{array}$ & $\begin{array}{l}0.0427^{* * *} \\
(0.00) \\
\end{array}$ \\
\hline College town Dummy & $\begin{array}{l}-0.0169^{\star \star \star} \\
(0.00)\end{array}$ & $\begin{array}{l}-0.0762^{* \star *} \\
(0.00)\end{array}$ & $\begin{array}{l}-0.0931^{\text {***}} \\
(0.00)\end{array}$ \\
\hline Population Density & $\begin{array}{l}-0.1905^{\star \star \star} \\
(0.00)\end{array}$ & $\begin{array}{l}-0.1071^{*} \\
(0.07)\end{array}$ & $\begin{array}{l}-0.2976^{\star * \star} \\
(0.00)\end{array}$ \\
\hline Area & $\begin{array}{l}-0.1990^{* * *} \\
(0.00)\end{array}$ & $\begin{array}{l}-0.0937^{* *} \\
(0.03)\end{array}$ & $\begin{array}{l}-0.2927^{* * *} \\
(0.00)\end{array}$ \\
\hline NAIX & $\begin{array}{c}0.0002 \\
(0.61)\end{array}$ & $\begin{array}{l}-0.0030^{*} \\
(0.09)\end{array}$ & $\begin{array}{c}-0.0032 \\
(0.13)\end{array}$ \\
\hline
\end{tabular}

p-levels are reported in parenthesis.

$* * *$ Significant at the $99 \%$ level

$* *$ Significant at the $95 \%$ level

*Significant at the $90 \%$ level 
Table 4.11: Model Averaged Estimates with Relative Coal Dependence Measure

\begin{tabular}{|c|c|c|c|}
\hline Variables & Direct Effects & Indirect Effects & Total Effects \\
\hline $\begin{array}{l}\text { Coal Production per Income } \\
\text { (\$) }\end{array}$ & $\begin{array}{l}0.0092^{* * *} \\
(0.00)\end{array}$ & $\begin{array}{l}0.0465^{*} \\
(0.05)\end{array}$ & $\begin{array}{l}0.0557^{* *} \\
(0.03)\end{array}$ \\
\hline Initial Income & $\begin{array}{l}0.6181^{* * *} \\
(0.00)\end{array}$ & $\begin{array}{c}-0.0183 \\
(0.79)\end{array}$ & $\begin{array}{l}0.5998^{* * *} \\
(0.00)\end{array}$ \\
\hline $\begin{array}{l}\text { Agriculture, Forestry, } \\
\text { Fisheries, Mining Emp. }\end{array}$ & $\begin{array}{l}-0.0154^{* \star *} \\
(0.00)\end{array}$ & $\begin{array}{c}-0.0193 \\
(0.14)\end{array}$ & $\begin{array}{l}-0.0347^{* * *} \\
(0.00)\end{array}$ \\
\hline Construction Emp. & $\begin{array}{c}0.0081 \\
(0.39) \\
\end{array}$ & $\begin{array}{c}-0.0141 \\
(0.56) \\
\end{array}$ & $\begin{array}{c}-0.0060 \\
(0.85) \\
\end{array}$ \\
\hline Manufacturing Emp. & $\begin{array}{l}-0.0076^{\star *} \\
(0.03)\end{array}$ & $\begin{array}{c}0.0063 \\
(0.44)\end{array}$ & $\begin{array}{l}-0.0016^{*} \\
(0.05)\end{array}$ \\
\hline $\begin{array}{l}\text { Transportation, } \\
\text { Communication and other } \\
\text { Public Utilities Emp. }\end{array}$ & $\begin{array}{c}0.0055 \\
(0.32)\end{array}$ & $\begin{array}{c}-0.0691 \\
(0.15)\end{array}$ & $\begin{array}{l}-0.0636 \\
(0.16)\end{array}$ \\
\hline $\begin{array}{l}\text { Wholesale and Retail Trade } \\
\text { Emp. }\end{array}$ & $\begin{array}{l}0.0027 \\
(0.79) \\
\end{array}$ & $\begin{array}{l}0.0462^{* *} \\
(0.03)\end{array}$ & $\begin{array}{l}0.0489^{\star \star} \\
(0.04)\end{array}$ \\
\hline $\begin{array}{l}\text { Finance, Insurance and Real } \\
\text { Estate Emp. }\end{array}$ & $\begin{array}{l}0.0259^{* * *} \\
(0.00)\end{array}$ & $\begin{array}{c}0.0328 \\
(0.30) \\
\end{array}$ & $\begin{array}{l}0.0587^{* *} \\
(0.03)\end{array}$ \\
\hline $\begin{array}{l}\text { Business and Repair } \\
\text { Services Emp. }\end{array}$ & $\begin{array}{l}0.0159^{* * *} \\
(0.00)\end{array}$ & $\begin{array}{c}0.0091 \\
(0.59) \\
\end{array}$ & $\begin{array}{c}0.0250 \\
(0.70) \\
\end{array}$ \\
\hline $\begin{array}{l}\text { Personal, Entertainment and } \\
\text { Recreation Services Emp. }\end{array}$ & $\begin{array}{c}0.0058 \\
(0.16) \\
\end{array}$ & $\begin{array}{l}0.0221 \\
(0.50)\end{array}$ & $\begin{array}{l}0.0279 \\
(0.41)\end{array}$ \\
\hline Health Services Emp. & $\begin{array}{l}0.0100 \\
(0.14)\end{array}$ & $\begin{array}{c}0.0266 \\
(0.42)\end{array}$ & $\begin{array}{c}0.0366 \\
(0.25)\end{array}$ \\
\hline Educational Services Emp. & $\begin{array}{l}-0.0420^{\star \star *} \\
(0.00)\end{array}$ & $\begin{array}{l}0.1185^{* *} \\
(0.02)\end{array}$ & $\begin{array}{l}0.0765^{\star \star} \\
(0.04)\end{array}$ \\
\hline $\begin{array}{l}\text { Other Professional and } \\
\text { Related Services Emp. }\end{array}$ & $\begin{array}{l}0.0048 \\
(0.38) \\
\end{array}$ & $\begin{array}{c}-0.0031 \\
(0.82) \\
\end{array}$ & $\begin{array}{c}0.0017 \\
(0.88) \\
\end{array}$ \\
\hline $\begin{array}{l}\text { Federal Government } \\
\text { Employment }\end{array}$ & $\begin{array}{l}0.0028 \\
(0.30)\end{array}$ & $\begin{array}{l}0.0477^{* *} \\
(0.01)\end{array}$ & $\begin{array}{c}0.0505 \\
(0.11)\end{array}$ \\
\hline $\begin{array}{l}\text { State Government } \\
\text { Employment }\end{array}$ & $\begin{array}{l}-0.0193^{\star \star *} \\
(0.00)\end{array}$ & $\begin{array}{c}0.0061 \\
(0.49) \\
\end{array}$ & $\begin{array}{c}-0.0132 \\
(0.46) \\
\end{array}$ \\
\hline $\begin{array}{l}\text { Local Government } \\
\text { Employment }\end{array}$ & $\begin{array}{c}-0.0155 \\
(0.11) \\
\end{array}$ & $\begin{array}{c}-0.0364 \\
(0.38) \\
\end{array}$ & $\begin{array}{c}-0.0519 \\
(0.21) \\
\end{array}$ \\
\hline Self Employment & $\begin{array}{l}0.0962^{* \star *} \\
(0.00)\end{array}$ & $\begin{array}{c}-0.0050 \\
(0.52)\end{array}$ & $\begin{array}{l}0.0912^{* * *} \\
(0.00)\end{array}$ \\
\hline Poverty & $\begin{array}{l}-0.0328^{* \star *} \\
(0.00)\end{array}$ & $\begin{array}{c}0.0185 \\
(0.21)\end{array}$ & $\begin{array}{c}-0.0143 \\
(0.26)\end{array}$ \\
\hline Human Capital & $\begin{array}{l}0.1195^{\star \star \star} \\
(0.00)\end{array}$ & $\begin{array}{l}-0.0770^{* *} \\
(0.01)\end{array}$ & $\begin{array}{l}0.0425^{* * *} \\
(0.00)\end{array}$ \\
\hline College town Dummy & $\begin{array}{l}-0.0171^{* * *} \\
(0.00)\end{array}$ & $\begin{array}{l}-0.0759^{* * *} \\
(0.00)\end{array}$ & $\begin{array}{l}-0.0930^{* * *} \\
(0.00)\end{array}$ \\
\hline Population Density & $\begin{array}{l}-0.1904^{* \star *} \\
(0.00)\end{array}$ & $\begin{array}{l}-0.1070^{*} \\
(0.07)\end{array}$ & $\begin{array}{l}-0.2974^{* * *} \\
(0.00)\end{array}$ \\
\hline Area & $\begin{array}{l}-0.1995^{\star \star \star} \\
(0.00)\end{array}$ & $\begin{array}{l}-0.0944^{* \star} \\
(0.03)\end{array}$ & $\begin{array}{l}-0.2939^{\star * \star} \\
(0.00)\end{array}$ \\
\hline NAIX & $\begin{array}{l}0.0003 \\
(0.61) \\
\end{array}$ & $\begin{array}{l}-0.0031^{*} \\
(0.08)\end{array}$ & $\begin{array}{c}-0.0028 \\
(0.13) \\
\end{array}$ \\
\hline
\end{tabular}

p-levels are reported in parenthesis.

$* * *$ Significant at the $99 \%$ level

$* *$ Significant at the $95 \%$ level

*Significant at the $90 \%$ level 
State government employment in own-county has a significant negative impact on own-county growth, suggesting an overexpansion of the state government. Unlike nonspatial models that find a negative association between federal government employment and growth, the results of the spatial growth regressions suggest that federal government employment in own-county do not hinder own-county growth. Indeed, although insignificant, the sign of the federal government employment estimate switches from negative to positive with the introduction of spatial dependence.

Self employment and poverty have positive and negative direct effects, respectively, and no significant spillover effects. Human capital imposes a positive direct impact and negative spillover effects, and its total impact is positive and significant at 99 percent level. Natural amenities index does not affect growth. Population density, which captures the agglomeration effects, has a strong negative impact on own-county growth. This result reflects the congestion effects and disamenities connected to large cities and denser areas. Another result of interest is that college towns are associated with lower income levels, capturing the impact of disproportionate number of students residing in college towns.

\subsection{Conclusion}

The negative association between resource abundance and poor economic performance has captured the attention of a wide range of audience, including academics, policy makers and international organizations. While the presence and the possible causal mechanisms of a resource curse have been extensively tested across countries, only a limited literature has extended the analysis using U.S. data. This study fills the gap in the 
literature by employing U.S. county level growth regressions and using both an absolute measure of resource abundance and a relative measure of resource dependence.

Another contribution of this paper is the employment of the appropriate spatial econometrics techniques in growth regressions to account for spatial spillovers and to distinguish between direct, indirect and total effects. Introducing spatial dependence into growth regressions changes the results drastically. Previous literature on resource curse has either used simple OLS or non-spatial growth models. As illustrated in this essay, when a relative measure of coal dependence is used, OLS results suggest a coal curse, while an absolute measure of coal abundance is not significant. These OLS results are consistent with the strand of cross-country growth literature that suggests that switching from relative measures of resource dependence to absolute measures of resource abundance makes the resource curse disappear across countries (Stijns, 2005; Brunnschweiler, 2007). This study uses spatial econometrics and reveals that the signs of the absolute and the relative coal abundance variables are reversed with the introduction of spatial dependence into county growth regressions. Unlike non-spatial models, the results suggest that when measured as a relative variable, coal dependence turns out to have a positive significant direct impact on own-county growth, and positive spillover impacts on related counties' growth. On the other hand, when measured as an absolute variable, coal abundance does not impact own-county growth, nor imposes spatial spillovers. This implies that accounting for spatial dependence in county growth regressions reverses the coal curse. One explanation for the presence of a resource curse is institutions and rent seeking. This finding may suggest that within the counties that 
share the same institutional structure, coal abundant counties may be better off in economic growth.

These results are in sharp contrast with the previous literature findings that suggest a negative association between point resources and economic growth. The results also contradict the previous findings that confirm the existence of a resource curse in the U.S. and Brunnschweiler and Bulte's (2008) results that suggest a positive relation between resource abundance and economic growth. Results from the spatial growth regressions imply that having coal resource endowment is not a curse for own-county growth, nor it causes negative spillovers on other counties. Future research should focus on employing spatial econometrics techniques to identify the presence of a resource curse across U.S. states. 
Chapter 5

\section{Conclusion}




\subsection{Conclusion}

This dissertation has addressed various spatial issues in housing markets and regional economic growth. Chapter 2 examines the impact of proximity to a coal mine on residential property values. Chapter 3 estimates U.S. county growth by applying Monte Carlo Markov Chain model composition with Bayesian model averaging to deal with model uncertainty in spatial regressions. Chapter 4 employs Monte Carlo Markov Chain model composition with Bayesian model averaging to examine whether coal abundance is a curse or a blessing for U.S. county economic growth.

The first essay, presented in Chapter 2, provides powerful insights regarding the price differential between single-family residential properties located in close proximity to a coal mine and comparable units away from it. A spatial hedonic price model is estimated using the Bayesian heteroskedastic SAR estimation procedure.

Proximity to coal mines is associated with both significant negative direct effects on own-house value and negative spillover effects on neighboring house values. The results suggest that houses located within $3 / 4$ mile of a coal mine sell for 16 percent less, while houses located within $3 / 4$ to 1 mile experience an 11 percent discount. Houses located within the next quarter of a mile sell for 10 percent less. Findings suggest that proximity effects disappear beyond 11/4 miles. These results reinforce previous hedonic analyses of environmental hazards that find a significant negative impact on house prices. These findings facilitate a better understanding of the costs coal mines impose on surrounding communities. Any cost-benefit analyses of coal mines should also consider discounted house values. A possible future extension may be the application of the estimation methodology to examine other locational disamenities that have yet to receive 
attention in the literature. For instance, it would be interesting to determine whether brownfields affect property values using spatial econometric techniques.

The second essay, presented in Chapter 3, applies Monte Carlo Markov Chain model composition with Bayesian model averaging on a sample of U.S. counties to deal with model uncertainty in spatial regressions and produce model averaged estimates and inferences. This study first reports spatial growth regression estimates using two different spatial weight matrix specifications (contiguity and optimal nearest neighbors) and demonstrates how different weight matrix specifications may lead to ambiguous results in spatial county growth regressions. Next, the Bayesian solution to model uncertainty is utilized to clarify the ambiguous estimates across different model specifications. The variables that are found to have ambiguous estimates across different specifications are human capital, employment in agricultural services, wholesale and retail trade, transportation and communication services, finance and real estate, entertainment and recreational services, health services, and natural amenities index. The Bayesian solution provides model averaged estimates and resolves the ambiguity pertaining to the significance of these variables. For instance, the model averaged estimates of human capital reveal that human capital imposes a positive direct impact and negative spillover impacts on related counties, and it has a positively significant total impact.

The third essay, presented in Chapter 4, applies the methodology from the second essay to the resource curse literature. The puzzling paradox of research scarce counties outperforming resource rich countries has created an intense "resource curse" debate among researchers, policy makers, and developmental organizations. Resource curse studies typically use a non-spatial growth model and a relative measure of resource 
abundance, and find evidence of a resource curse. However, several researchers contest the use of resource dependence measures and argue that switching from relative measures to absolute measures makes the resource curse disappear (Stijns, 2005; Brunnschweiler, 2007). This study contributes to this line of literature by using both an absolute and a relative measure of coal abundance, and employing U.S. county level spatial growth regressions to examine whether coal abundance has been a curse or a blessing for county growth.

The results suggest that spatial growth regressions produce results that are very different from OLS regression results. With a relative measure of coal dependence, OLS results suggest a coal curse, while an absolute measure of coal abundance is not significant. These OLS results are consistent with the line of cross-country growth literature that suggests that switching from relative measures of resource dependence to absolute measures of resource abundance makes the resource curse disappear across countries.

The introduction of spatial dependence into county growth regressions results in reversed signs of the absolute and the relative coal abundance variables. Unlike nonspatial models, the results suggest that when measured as a relative variable, coal dependence turns out to have a positive significant direct impact on own-county growth, and positive spillover impacts on related counties' growth. On the other hand, when measured as an absolute variable, coal abundance does not impact own-county growth, nor imposes spatial spillovers. The results of this study imply that switching from nonspatial growth models to spatial growth models reverses the coal curse. 
A possible area of future research involves employing spatial econometric techniques on a sample of U.S. states to identify the presence and possible transmission channels of a resource curse. Another possible direction of future research would involve introducing spatial econometrics in estimating state level growth regressions. Non-spatial growth regressions often find a negative association between the size of the federal government and growth. This is interpreted as an overexpansion of the federal government. However, as demonstrated in Chapter 4 of this dissertation, introduction of spatial econometrics into county growth regressions results in a reversed sign of the federal government employment variable. Unlike non-spatial models, the results suggest a positive magnitude (however insignificant) of the federal government employment estimate. It would be interesting to employ a state level spatial growth regression and the methodology described in this dissertation on a sample of U.S. states to examine the role of different levels of government on economic growth. 


\section{References}

1. Abreu, M., H. L. F. de Groot, and R. J. G. M. Florax. "Space and Growth: a Survey of Empirical Evidence and Methods," Tinbergen Institute Working Paper No. TI 04-129/3. Internet site: http://ssrn.com/abstract=631007, (2004).

2. Anderson, S. T. and S. E. West. "Open Space, Residential Property Values, and Spatial Context," Regional Science and Urban Economics, 36, 773-789, (2006).

3. Anselin, L. Spatial Econometrics: Methods and Models, Kluwer Academic Publishers, Dordrecht, (1988).

4. Anselin, L. and A. Bera. "Spatial Dependence in Linear Regression Models with an Introduction to Spatial Econometrics", in A. Ullah, D. Giles (Eds.), Handbook of Applied Economic Statistics, Marcel Dekker, New York, 237-289, (1998).

5. Atkinson, G. and K. Hamilton. "Savings, Growth and the Resource Curse Hypothesis," World Development, 31, 1793-1807, (2003).

6. Auty, R. M. Resource Abundance and Economic Development. Oxford University Press, (2001).

7. Barro, R. Determinants of Economic Growth: A Cross-Country Empirical Study. Cambridge: MIT Press, (2007).

8. Brasington, D. M. and D. Hite. "Demand for Environmental Quality: A Spatial Hedonic Analysis," Regional Science and Urban Economics, 35, 57-82, (2005).

9. Brock, W. and S. Durlauf. "Growth Empirics and Reality," The World Bank Economic Review, 15(2), 229-272, (2001). 
10. Brunnschweiler, C. N. and E. H. Bulte. "The Resource Curse Revisited and Revised: A Tale of Paradoxes and Red Herrings," Journal of Environmental Economics and Management, 55, 248-264, (2008).

11. Brunnschweiler, C. N. "Cursing the Blessings? Natural Resource Abundance, Institutions, and Economic Growth," World Development, 36, 399-419, (2008).

12. Bulte, E. H., R. Damania and R. T. Deacon. "Resource Intensity, Institutions and Development," World Development, 33(7), 1029-1044, (2005).

13. Carlino, G. A. and E. S. Mills. "The Determinants of County Growth," Journal of Regional Science, 27(1), 39-54, (1987).

14. Chattopadhyay, S. "Estimating the Demand for Air Quality: New Evidence Based in the Chicago House Market," Land Economics, 75, 174-194, (1999).

15. Clark, D. E., Michelbrink, L., Allison, T. and W. C. Metz. "Nuclear Power Plants and Residential Housing Prices," Growth and Change, 28, 496-519, (1997).

16. Cohen, J. P. and C. C. Coughlin. "Spatial Hedonic Models of Airport Noise, Proximity, and Housing Prices," Journal of Regional Science, 48(5), 859-878, (2008). 17. Corey, J. “The Resource Curse: Institutions, Economic Freedom and Growth across U.S. States, Working Paper, (2009).

18. Delaney. C.J. and D. Timmons. "High Voltage Power Lines: Do They Affect Residential Property Value?” Journal of Real Estate Research, 7, 315-329, (1992). 19. Deller, S. and V. Lledo. "Amenities and Rural Appalachia Economic Growth," Agricultural and Resource Economic Review, 36(1), 107-132, (2007). 
20. Denison, D. G. T., B. K. Mallick, and A. F. M. Smith. “Automatic Bayesian Curve Fitting," Journal of the Royal Statistical Society, Series B, 60(2), 333-350, (1998).

21. Des Rosiers, F. "Power Lines, Visual Encumbrance and House Values: A Microspatial Approach to Impact Measurement," The Journal of Real Estate Research, 23(3): 275-300, (2002).

22. Des Rosiers, F., Bolduc, A. and M. Theriault. "Environment and Value: Does Drinking Water Quality Affect House Prices?" The Journal of Property Investment and Finance, 17(5), 444-463, (1999).

23. Dunn, L. "The Resource Curse in U.S. States: A Rent-Seeking Model," Working Paper, (2008).

24. Durlauf, S. and D. Quah. "The New Empirics of Economic Growth,” In J. Taylor and M. Woodford, eds., Handbook of Macroeconomics. Amsterdam: North Holland, (1999).

25. Espey, M., and H. Lopez. "The Impact of Airport Noise and Proximity on Residential Property Values," Growth and Change, 31, 408-419, (2000).

26. Fernandez, C., E. Ley and M. F. J. Steel. "Model uncertainty in Cross-Country Growth Regressions,” Journal of Applied Econometrics, 16(5), 563-576, (2001a).

27. Fernandez, C., E. Ley and M. F. J. Steel. "Benchmark Priors in Bayesian Model Averaging," Journal of Econometrics, 100(2), 381-427, (2001b).

28. Fingleton, B. “Theoretical Economic Geography and Spatial Econometrics:

Dynamic Perspectives," Journal of Economic Geography, 1, 201-225, (2001). 
29. Gamble, H. B., and R. H. Downing. "Effects of Nuclear Power Plants on

Residential Property Values,” Journal of Regional Science, 22, 457-478, (1982).

30. Gebremariam, G. H., T. G. Gebremedhin and P. V. Schaeffer. "Analysis of County Employment and Income Growth in Appalachia: A Spatial SimultaneousEquations Approach,” Empirical Economics, (2009).

31. Geoghegan J., Lynch, L. and S. Bucholz. "Capitalization of Open Space into Housing Values and the Residential Property Tax Revenue Impacts of Agricultural Easement Programs," Agricultural and Resource Economics Review, 32, 33-45, (2003).

32. Glayfason, T. Natural Resources, Education and Economic Development," European Economic Review, 45, 847-859, (2001).

33. Goldberg, E., E. Wibbels and E. Mvukiyehe. "Lessons from Strange Cases: Democracy, Development, and the Resource Curse in the U.S. States," Comparative Political Studies, 41, 477-514, (2008).

34. Graves, P., Murdoch, J. C., Thayer, M. A. and D. Waldman. "The Robustness of Hedonic Price Estimation: Urban Air Quality," Land Economics, 64(3), 220-233, (1988).

35. Guntermann, K. L. and P. F. Colwell. "Property Values and Accessibility to Primary Schools," Real Estate Appraiser \& Analyst, 49(1), 62-68, (1983).

36. Hendryx. M. and M. M. Ahern. "Relations Between Health Indicators and Residential Proximity to Coal Mining in West Virginia," American Journal of Public Health, (2008). 
37. Hendryx. M. "Mortality from Heart, Respiratory and Kidney Disease in Coal Mining Areas of Appalachia," International Archives of Occupational and Environmental Health, 82, 243-249, (2009).

38. Hendryx. M. and M. M. Ahern. "Mortality in Appalachian Coal Mining Regions: The Value of Statistical Life Lost," Public Health Reports, July-August issue (2009). 39. Higgins, M. J., D. Levy and A. T. Young. "Growth and Convergence Across the United States: Evidence from County-Level Data," The Review of Economics and Statistics, 88, 671-681, (2006).

40. Hite, D., Chern, F. H. and A. Randall; "Property Value Impacts of an Environmental Disamenity: The Case of Landfills," Journal of Real Estate Economics, 22, 185-202, (2001).

41. Hoehn, J. P., Berger, M. C. and G. C. Blomquist. "A Hedonic Interregional Wages, Rents, and Amenity Values," Journal of Regional Science, 27, 605-620, (1987).

42. Hoeting, J. A., D. Madigan, A. E. Raftery, and C. T. Volinsky. "Bayesian Model Averaging: A Tutorial,” Statistical Science, 14(4), 382-417, (2001).

43. Irwin, E. "The Effects of Open Space on Residential Property Values," Land Economics, 78, 465-480, (2002).

44. Isham, J., M. Woolcock, L. Pritchett and G. Busby. "The Varieties of Resource Experience: Natural Resource Export Structures and the Political Economy of Economic Growth," The World Bank Economic Review, 19(2), 141-174, (2005). 
45. Kiel, K. A. and K. T. McClain. "House Prices Through Sitting Decision Stages: The Case of an Incinerator from Rumor through Operation," Journal of Environmental Economics and Management, 25, 241-255, (1995).

46. Kim, C. W., Phipps, T. T. and L. Anselin. "Measuring the Benefits of Air Quality Improvement: A Spatial Hedonics Approach," Journal of Environmental Economics and Management, 45, 24-39, (2003).

47. Ledermann, D. and W. F. Maloney. "Trade Structure and Growth,” World Bank Policy Research Working Paper, \# 3025, (2003).

48. Leite, C. and J. Weidmann. "Does Mother Nature Corrupt? Natural Resources, Corruption and Economic Growth," IMF Working Paper, WP/99/85, (1999).

49. LeSage, J. P. and R. K. Pace. Introduction to Spatial Econometrics, Taylor and Francis, Inc., (2009).

50. LeSage, J. P. and M. M. Fischer. "Spatial Growth Regressions: Model Specification, Estimation and Interpretation," Spatial Economic Analysis, 3(3), 275304, (2008).

51. LeSage, J. P. and O. Parent. "Bayesian Model Averaging for Spatial Econometric Models," Geographical Analysis, 39(3), 241-267. (2007).

52. LeSage, J. P. "The Theory and Practice of Spatial Econometrics", (1999). Available on www.spatial-econometrics.com.

53. Levernier, W., Partridge, M. D., and Rickman, D, S. “The Causes of Regional Variation in US Poverty: A Cross-County Analysis", Journal of Regional Science, 40(3), 473-497, (2000). 
54. Levine, R. and D. Renelt. "A Sensitivity Analysis of Cross-Country Growth Regressions," American Economic Review, 82(4), 942-963, (1992).

55. Madison, D. and J. York. "Bayesian Graphical Models for Discrete Data”, International Statistics Review, 63(2), 215-232, (1995).

56. Pack, H. "Endogenous Growth Theory: Intellectual Appeal and Empirical Shortcomings," Journal of Economic Perspectives, 8(1), 55-72, (1994).

57. Papyrakis, E. and R. Gerlagh. "Resource Abundance and Economic Growth in the United States,” European Economic Review, 51, 1011-1039, (2007).

58. Raftery, A. E., D. Madigan, and J. A. Hoeting. "Bayesian Model Averaging for Linear Regression Models," Journal of the American Statistical Association, 92(437), 179-191, (1997).

59. Raftery, A. E. "Bayesian Model Selection in Social Research," In P. Marsden, ed., Sociological Methodology. Cambridge: Blackwell, (1995).

60. Ready, R. C., Berger, M. C. and G. C. Blomquist. "Measuring Amenity Benefits from Farmland: Hedonic Pricing vs. Contingent Valuation," Growth and Change, 28, 438-458, (1997).

61. Rosen, Sherwin. "Hedonic Prices and Implicit Markets: Product Differentiation in Pure Competition," The Journal of Political Economy, 82, 34-55, (1974).

62. Rupasingha, A. and Goetz, S, J. "Social and Political Forces as Determinants of Poverty: A Spatial Analysis”, The Journal of Socio-Economics. 36, 650-671, (2007).

63. Rupasingha, A., Goetz, S, J., and Freshwater, D. "Social and Institutional Factors as Determinants of Economic Growth: Evidence from the United States Counties”, papers in Regional Sciences. 81(2), 139-155, (2002). 
64. Sachs, J. D. and A. M. Warner. "The Curse of Natural Resources," European Economic Review, 45, 827-838, (2001).

65. Sachs, J. D. and A. M. Warner. "Natural Resource Abundance and Economic Growth,” NBER Working Paper \#5398, (1995).

66. Sala-i-Martin, X. and A. Subramanian. "Addressing the Natural Resource Curse: An Illustration from Nigeria,” NBER Working Paper \#9804, (2003).

67. Sala-i-Martin, X. "I Just Ran Two Million Regressions," American Economic Review, 87(2), 178-183, (1997).

68. Schultz, T. P. "Health and Schooling Investments in Africa," Journal of Economic Growth, 13(2), 67-88, (1999).

69. Shi, Y. J., Phipps, T. T. and D. Colyer. "Agricultural Land Values under Urbanizing Influences," Land Economics, 73, 90-100, (1997).

70. Stijns, J-P. C. "Natural Resource Abundance and Economic Growth Revisited," Resources Policy, 30, 107-130, (2005).

71. Tomkins, J., N. Topham, J. Twomey, and R. Ward. "Noise versus Access: The Impact of an Airport in an Urban Property Context," Urban Studies, 2, 243-258, (1998).

72. Torvik, R. "Natural Resources, Rent Seeking and Welfare. Journal of Development Economics, 67, 455-470, (2002).

73. Torvik, R. "Learning by Doing and the Dutch Disease," European Economic Review, 45, 285-306, (2001).

74. U.S. Census Population Statistics Database. 
75. Williamson, J. M., H. W. Thurston, and M. T. Heberling. "Valuing Acid Mine Drainage Remediation in West Virginia: A Hedonic Modeling Approach," Annals of Regional Science, 42, 987-999, (2008).

76. Young, A. T., M. J. Higgins, and D. Levy. "Sigma Convergence versus Beta Convergence: Evidence from U.S. County-Level Data," Journal of Money Credit Bank, 40(5): 1083-1093, (2008).

77. Zellner, A. An Introduction to Bayesian Inference in Econometrics, New York, John Wiley, (1971). 
ARZU SEN

West Virginia University

Department of Economics

P.O. Box 6025

Morgantown, WV 26505

Website: http://sites.google.com/site/arzusenwvu/
Work: (304) 293-5993

Cell: (304) 685-9911

E-Mail: Arzu.Sen@mail.wvu.edu

\section{Education:}

Ph.D. in Economics, West Virginia University, Expected Graduation August 2010. Dissertation: $\quad$ Three Essays on Housing Markets and Economic Growth Committee: $\quad$ Brian J. Cushing (Chair), Tim T. Phipps, Peter V. Schaeffer, Russell S. Sobel, Tami Gurley-Calvez Primary Fields: $\quad$ Urban and Regional Economics, Public Economics, Applied Microeconomics

Secondary Fields: $\quad$ Spatial Econometrics, Economic Growth and Development, Natural Resource and Environmental Economics

M.A. in Financial Economics, Izmir University of Economics, Izmir, Turkey, August 2005.

M.A. in Economics, Dokuz Eylul University, Izmir, Turkey, August 2004.

B.S. in Economics, Middle East Technical University, Ankara, Turkey, June 2002.

\section{Refereed Publications:}

"What Drives Road Rage?" with Pavel Yakovlev, Atlantic Economic Journal (Anthology), September 2008, 36: 361-362.

"Beauty and the Beast: An Empirical Tale of City Attributes," with Pavel Yakovlev, Economics Bulletin, 2007, Vol. 18: 1-9.

\section{Research in Progress:}

"Effects of Coal Mines on Residential Property Values: A Spatial Hedonic Analysis," under review.

"Resource Curse in U.S. Coal Counties: A Spatial County Growth Analysis," working paper.

"U.S. County Growth: A Bayesian Model Averaging Approach,” working paper.

"Preventing Regional Conflicts as a Global Public Good: The Case of the MENA Region," with Mehmet Serkan Tosun, working paper. 
"Rational Discrimination Against Young Women? Evidence from a Labor Market Experiment" with Susane J. Leguizamon, working paper.

“On the Determinants of Arms Trade," with Pavel Yakovlev, working paper.

\section{Policy Research:}

"The West Virginia Property Tax," with Amy Higginbotham, and Tami Gurley-Calvez, West Virginia Business and Economic Review, Spring 2009, Vol. 16: 3-8.

"Teacher Shortages: National and Regional Perspectives," with Tom Witt, Amy Higginbotham, and Tami Gurley-Calvez, West Virginia Business and Economic Review, Winter 2008, Vol. 15: 8-10.

"The Economic Incidence of West Virginia Taxes from 1999 to 2004," with Mehmet Tosun, and Pavel Yakovlev, West Virginia Business and Economic Review, Spring 2007, Vol. 14: 1-4.

"Effects of Customs Union on Turkish Economy,” with Oguz Esen, Ayla Ogus, and Ismail Bulmus. Prepared for Izmir Chamber of Commerce, 2005.

\section{Book Chapters:}

"Retirees and Economic Development in West Virginia" chapter with Mehmet Tosun, Pavel Yakovlev, and Claudia Williamson, in Demographic Economics Research Perspectives, Pavel E. Gordeev ed., Nova Science Publishers: 1-42, 2008.

\section{Other Research Experience and Employment:}

Research Assistant, Bureau of Business and Economic Research, West Virginia University, 2005-2008.

\section{Teaching Experience:}

Instructor with full teaching responsibilities, West Virginia University, Department of Economics:

Principles of Microeconomics-online: Summer 2010

Principles of Microeconomics: Spring 2010

Regional Economics: $\quad$ Fall 2009

Principles of Macroeconomics: Summer 2009

Principles of Microeconomics: Spring 2009

Principles of Microeconomics: $\quad$ Fall 2009

Principles of Macroeconomics: Summer 2008

Principles of Macroeconomics: Summer 2007

Elementary Business and Economic Statistics: Summer 2006 
Teaching Assistant, Izmir University of Economics, Department of Economics

Principles of Macroeconomics:

Spring 2005

Principles of Microeconomics:

Fall 2004

Principles of Macroeconomics:

Spring 2004

Workshop for Business and Economics II: Spring 2004

Principles of Microeconomics:

Fall 2003

Workshop for Business and Economics I:

Fall 2003

\section{Workshops:}

Computable General Equilibrium Modeling Workshop, Regional Research Institute, West Virginia University, August 10-13, 2009, by Karen Turner (University of Strathcylde, UK).

Spatial Econometrics Workshop, Regional Research Institute, West Virginia University, May 11-14, 2009, by James LeSage (Texas State University).

ESRI Introduction to ArcGIS I Workshop, West Virginia University, March 18-19, 2009, by Kevin Kuhn (WV GIS Technical Center).

\section{Conference Presentations:}

"U.S. County Growth: A Bayesian Model Averaging Approach,"

2010 Southern Regional Science Association $49^{\text {th }}$ Annual Conference, Arlington, VA-Washington, DC.

"Effects of Coal Mines on Residential Property Values: A Spatial Hedonic Analysis"

2009 Southern Economic Association $79^{\text {th }}$ Annual Meetings, San Antonio.

2008 Southern Economic Association $78^{\text {th }}$ Annual Meetings, Washington, DC.

2008 Southern Regional Science Association 47 ${ }^{\text {th }}$ Annual Conference, Arlington, VA-Washington, DC.

"Resource Curse in U.S. Coal Counties: A Spatial County Growth Analysis" 2009 Southern Regional Science Association $48^{\text {th }}$ Annual Conference, San Antonio, TX.

"Conflict Prevention as a Public Good? The Case of the Middle East and North Africa Region," with Mehmet Serkan Tosun.

2008 National Tax Association 101 ${ }^{\text {st }}$ Annual Conference, Philadelphia, PA.

Discussant

2010 Southern Regional Science Association $49^{\text {th }}$ Annual Conference, Arlington, VA-Washington, DC.

2009 Southern Economic Association $79^{\text {th }}$ Annual Meetings, San Antonio. 2008 Southern Economic Association $78^{\text {th }}$ Annual Meetings, Washington, DC. 
2008 Southern Regional Science Association 4 $7^{\text {th }}$ Annual Conference, Arlington, VA-Washington, DC.

2006 Southern Economic Association $76^{\text {th }}$ Annual Meetings, Charleston, SC.

2005 National Tax Association $98^{\text {th }}$ Annual Conference on Taxation, FL.

\section{Awards:}

Dadisman Graduate Assistant Supplement Award, 2007-2009.

An additional stipend awarded to third and fourth year Graduate Assistants making appropriate progress towards the Ph.D. degree.

\section{Computer Skills:}

STATA, MATLAB, SAS, EViews, ArcGIS, IMPLAN

\section{Affiliations:}

Southern Economic Association, Southern Regional Science Association, North American Regional Science Association

\section{References:}

Brian J. Cushing (Advisor)

Associate Professor of Economics

Department of Economics

West Virginia University

P.O. Box 6025

Morgantown, WV 26505-6025

Phone: (304) 293-7881

brian.cushing@mail.wvu.edu
Santiago M. Pinto

Associate Professor of Economics

Department of Economics

West Virginia University

P.O. Box 6025

Morgantown, WV 26505-6025

Phone: (304) 293-7871

smpinto@mail.wvu.edu

Tami Gurley-Calvez

Research Assistant Professor

Bureau of Business and Economic Research

West Virginia University

P.O. Box 6025

Morgantown, WV 26505-6025

Phone: (304) 293-7829

tami.calvez@mail.wvu.edu 